\author{
Marquette University \\ e-Publications@Marquette
}

\title{
Anaerobic Co-digestion for Enhanced Renewable Energy and Green House Gas Emission Reduction
}

Navaneethan Navaratnam

Marquette University

Follow this and additional works at: https://epublications.marquette.edu/dissertations_mu

Part of the Civil and Environmental Engineering Commons

\section{Recommended Citation}

Navaratnam, Navaneethan, "Anaerobic Co-digestion for Enhanced Renewable Energy and Green House Gas Emission Reduction" (2012). Dissertations (1934 -). 192.

https://epublications.marquette.edu/dissertations_mu/192 


\title{
ANAEROBIC CO-DIGESTION FOR ENHANCED RENEWABLE ENERGY AND GREEN HOUSE GAS EMISSION REDUCTION
}

by

Navaneethan Navaratnam

\begin{abstract}
A Dissertation submitted to the Faculty of the Graduate School, Marquette University, in Partial Fulfillment of the Requirements for the Degree of Doctor of Philosophy
\end{abstract}

Milwaukee, Wisconsin

May 2012 


\title{
ABSTRACT \\ ANAEROBIC CO-DIGESTION FOR ENHANCED RENEWABLE \\ ENERGY AND GREEN HOUSE GAS \\ EMISSION REDUCTION
}

\author{
Navaneethan Navaratnam
}

Marquette University, 2012

The need to develop renewable energy is important for replacing fossil fuel, which is limited in quantity and also tends to increase in price over time. The addition of high strength organic wastes in municipal anaerobic digesters is growing and tends to increase renewable energy production. In addition, conversion of wastes to energy significantly reduces uncontrolled greenhouse gas emissions. Co-digestion of municipal sludge with any combination of wastes can result in synergistic, antagonistic or neutral outcomes. The objectives of this study were to identify potential co-digestates, determine synergistic, antagonistic and neutral effects, determine economic benefits, quantify performance of bench scale co-digesters, identify influence of co-digestion on microbial communities and implement appropriate co-digestion, if warranted, after full-scale testing. A market study was used to identify promising co-digestates. Most promising wastes were determined by biochemical methane potential (BMP) and other testing followed by a simple economic analysis. Performance was investigated using bench-scale digesters receiving synthetic primary sludge with and without co-digestates. Denaturing gradient gel electrophoresis (DGGE) and quantitative polymerase chain reaction (qPCR) analyses were performed on the gene encoding the $\alpha$ subunit of methyl coenzyme $\mathrm{M}$ reductase (mcrA) to compare methanogen communities among the digesters. One significant band contributing to the greatest difference in banding patterns was excised, cloned, amplified and sequenced. Fullscale co-digestion was conducted using the most promising co-digestate at South Shore Wastewater Reclamation Facility (Oak Creek, WI). Over 80 wastes were identified from 54 facilities within $160 \mathrm{~km}$ of an existing municipal digester. A simple economic comparison identified the greatest benefits for seven co-digestates. Methane production rates of two codigester systems increased by $105 \%$ and $66 \%$ in comparison to a control system. These increases were great than anticipated based on theoretical methane production from the additional chemical oxygen demand (COD) of the co-digestates. Co-digestion of the most promising wastes with primary sludge was estimated to generate enough electricity to power more than 2500 houses. Synergistic outcomes of co-digestion may be caused by chances in microbial community resulting in more rapid methane production rate and higher specific methanogenic activities of the biomass against acetate, propionate and $\mathrm{H}_{2}$ as substrates. The presence of Methanospirillum hungatei correlated to higher SMAs in the Co-Digester 1 system. In subsequent full-scale testing, acid whey in addition to primary sludge increased methane production by $16 \%$, biogas methane content by $5 \%$, methane yield per VS destroyed by $9 \%$ ( from 650 to $710 \mathrm{~L} \mathrm{CH}_{4} / \mathrm{kg} \mathrm{VS}$ destroyed ) and volatile solids removal by $20 \%$. Co-digestion is a promising technology to increase renewable energy production and convert municipal digesters into regional renewable energy facilities. 


\title{
ACKNOWLEDGEMENTS
}

\author{
Navaneethan Navaratnam
}

I would like to express my profound gratitude to the chairman of my advisory committee, Dr. Daniel Zitomer, for giving me the opportunity to study for my doctoral degree at Marquette University. He provided good advice and great guidance regarding my $\mathrm{Ph}$.D. research work throughout this study. He always encouraged me to present papers at conferences and publish in scientific journals. I would like to thank my advisory committeee members, Dr. Michael Switzenbaum, Dr. James Maki, and Dr. Zhen He for their guidance and valuable suggestions throughout this research work. I am grateful to the US Department of Energy, Milwaukee Metropolitan Sewage District (MMSD), and WE Energies for funding this research work.

I also express my sincere thanks to the staff who worked on the full scale co-digestion at South Shore Wastewater Reclamation Facility, especially, Peter Topczewski from MMSD and Scott Royer from Veolia Water Milwaukee who worked towards success of full-scale codigestion. I express my great appreciation to the Marquette University environmental lab manager, Mike Dollhopf, for helping with the required equipment and chemicals for the research analysis. He was not only a lab manager, but also was involved and worked on part of this project. Acknowledgements are extended to all the past and present members of the research team, including Dr. Anne Schauer-Gimenez, Dr. Vaibhav Tale, Dr. Rachel Morris, Ujwal Bhattad, Benjamin Bocher, and Steve Graziano for all of their help with lab work. I express thanks to Parwinder Virk and Jonathan Kusowski, the undergraduate students who helped me in the lab.

I would also like to specially thank Tom Silman, the technician at the Discover Learning Center, Marquette University. He helped to fabricate the bench-scale digesters. I am grateful to my wife, Vimali, who has always given me useful advice, inspiration as well as mental support throughout my $\mathrm{PhD}$ study. 
TABLE OF CONTENTS

Title

Page

ACKNOWLEDGEMENTS

i

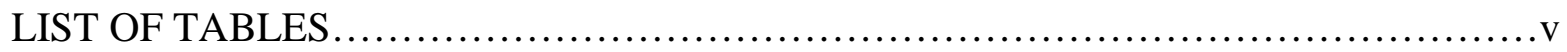

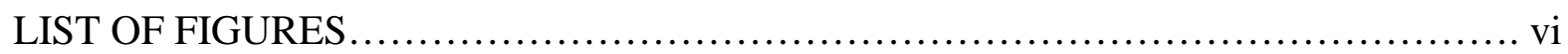

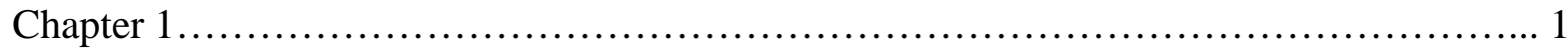

ANAEROBIC CO-DIGESTION FOR INCREASED RENEWABLE ENERGY ................ 1

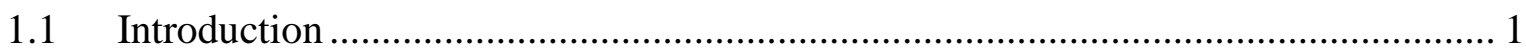

1.1.1 Anaerobic digestion and anaerobic co-digestion ........................................ 1

1.1.2 Advantages and disadvantage of anaerobic co-digestion ............................... 4

1.1.3 Disadvantage of anaerobic co-digestion .................................................. 5

1.1.4 Synergism, anatonistic and neutral outcomes .......................................... 6

1.1.5 Biochemical methane potential (BMP) test .............................................. 7

1.1.6 Anerobic toxicity assay (ATA) test ....................................................... 7

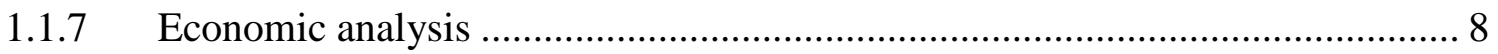

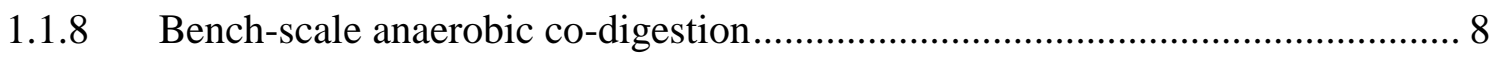

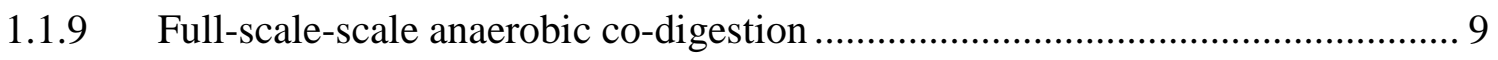

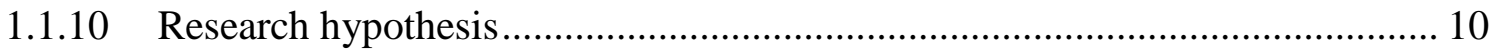

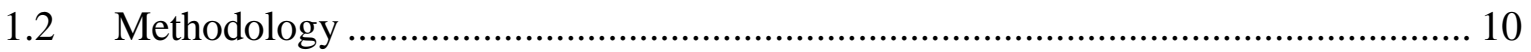

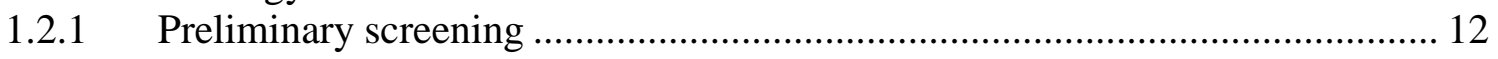

1.2.2 Identify most promising co-digestates .................................................. 12

1.2.2.1 Biochemical methane potential (BMP) testing ..................................... 13

1.2.2.2 Anaerobic Toxicity Assay (ATA) testing ........................................... 14

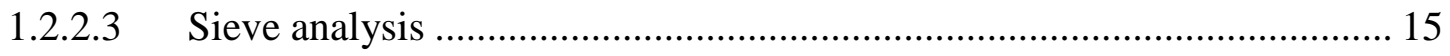

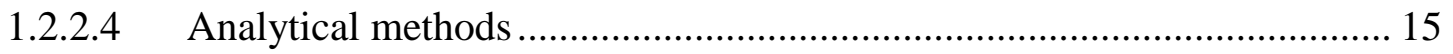

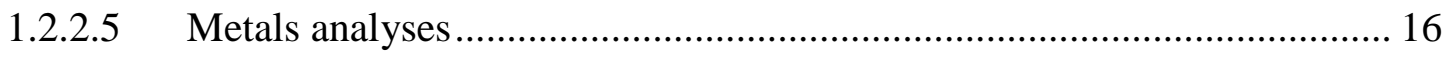

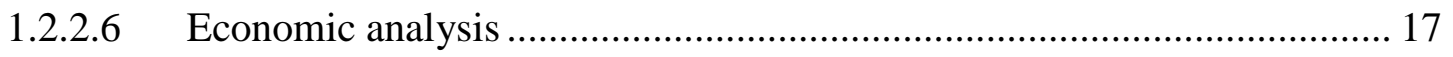

1.2.3 Performance of bench-scale anaerobic digesters ...................................... 18

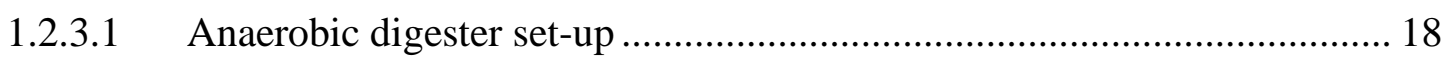

1.2.3.2 Digester start-up and operation........................................................ 19

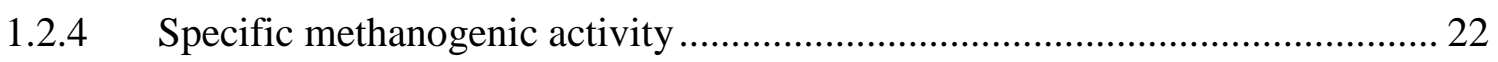

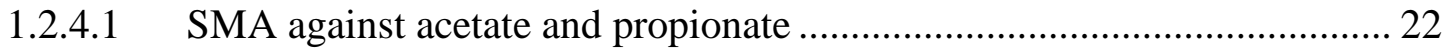

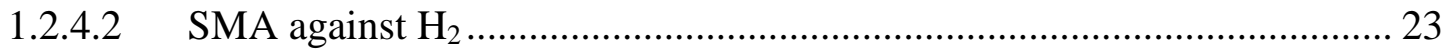

1.2.5 Co-Digestion with synergistic, antagonistic and neutral outcomes ................. 24

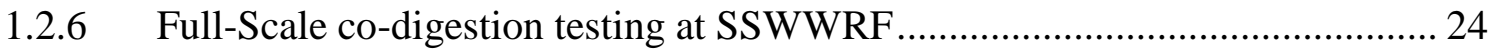




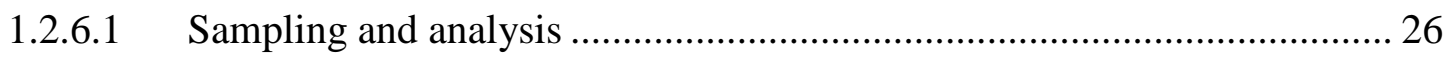

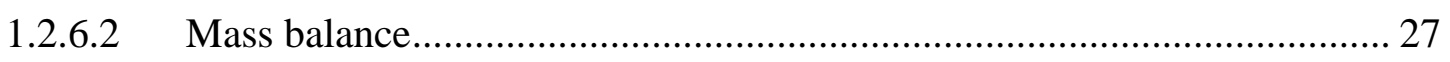

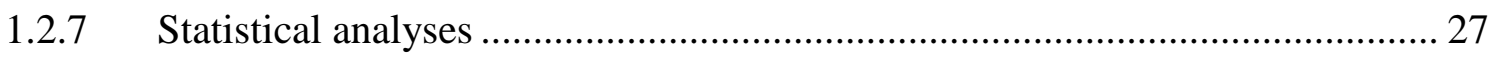

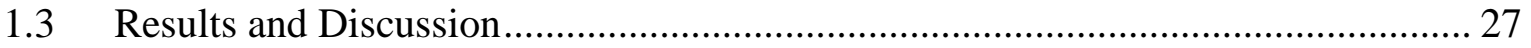

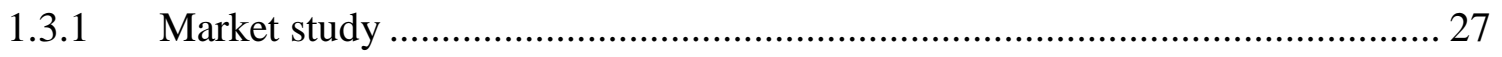

1.3.2 Identify most promising co-digestates …………………………………...... 29

1.3.2.1 Constituent analyses ............................................................................. 32

1.3.2.2 Biochemical methane potential (BMP) testing......................................... 40

1.3.2.3 Anaerobic toxicity assay (ATA) testing ................................................. 42

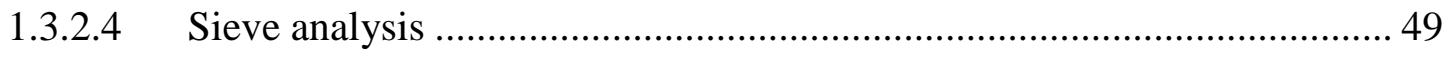

1.3.2.5 Cost-benefit analysis............................................................................... 49

1.3.3 Performance of bench-scale anaerobic digesters ............................................. 51

1.3.3.1 $\mathrm{CH}_{4}$ production and biogas composition ................................................ 51

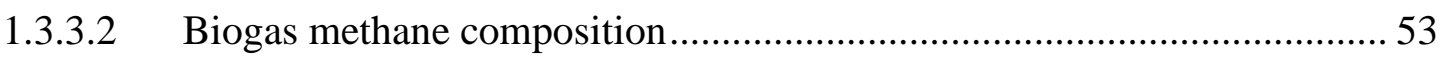

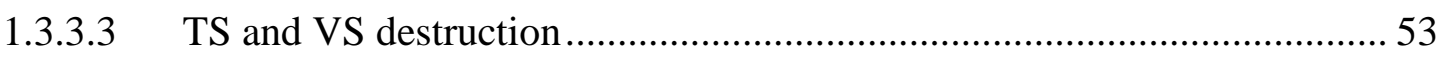

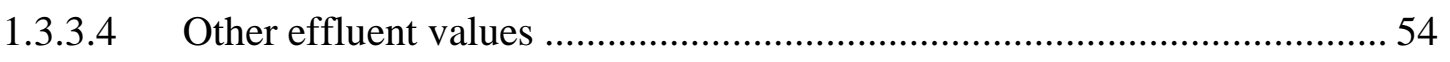

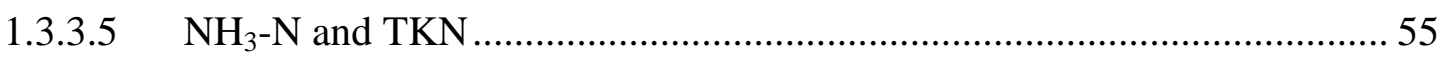

1.3.3.6 Estimated benefit of full scale co-digestion based on bench-scale digester.. 56

1.3.4 Specific methanogenic activity (SMA) of biomass ……………………........ 57

1.3.4.1 SMA against acetate and propionate …………....................................... 57

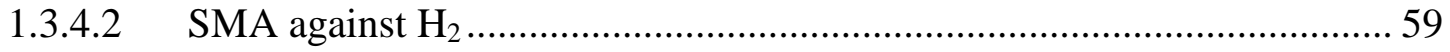

1.3.5 Synergistic, antagonistic and neutral outcomes for different wastes ................. 61

1.3.6 Full-scale co-digestion testing at SSWWRF.................................................... 63

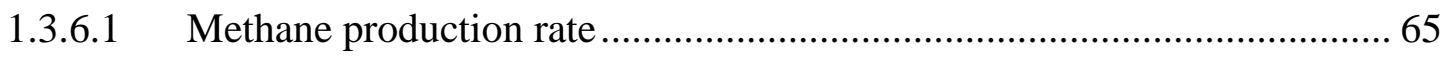

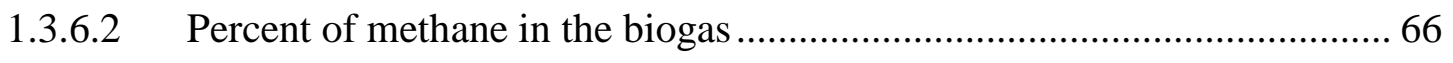

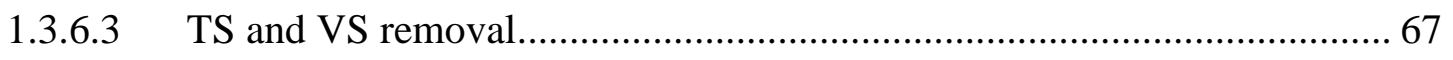

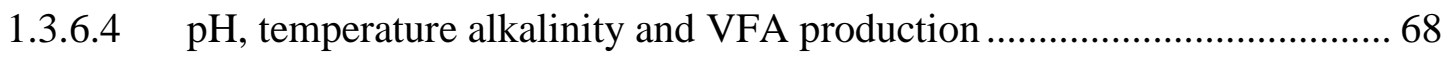

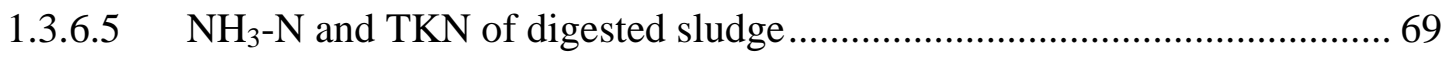

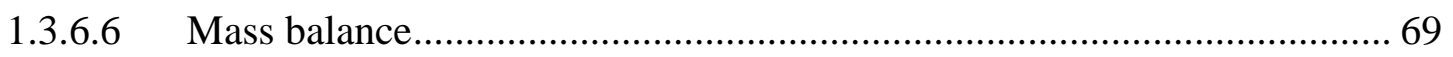

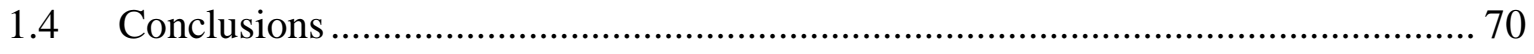

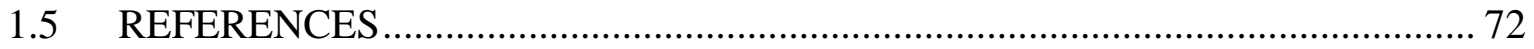

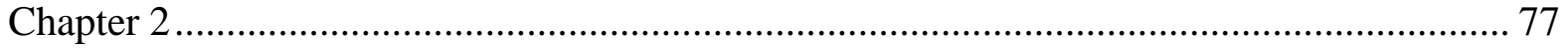

ANAEROBIC CO-DIGESTION WITH SYNERGISTIC WASTE INCREASES

MICROBIAL ACTIVITY AND CHANGES THE MICROBIAL COMMUNITY ............... 77 


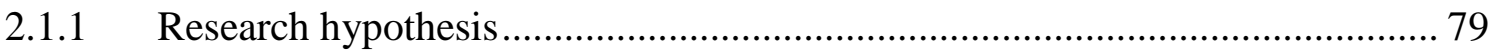

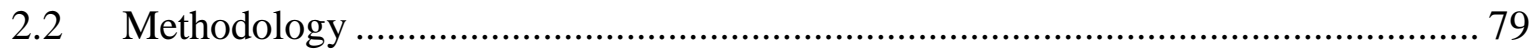

2.2.1 Specific methanogenic activity ................................................................... 79

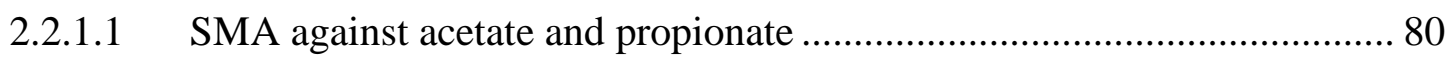

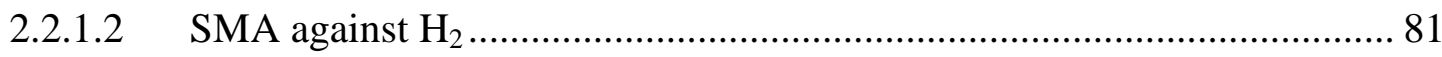

2.2.2 Influence of co-digestion on diversity and population of digester

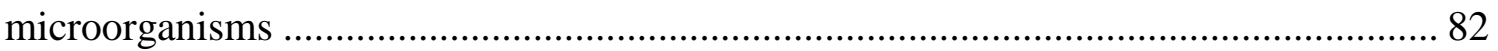

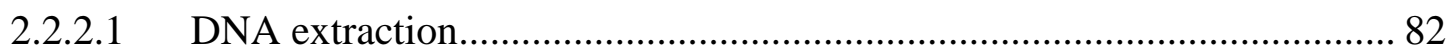

2.2.2.2 Agarose gel electrophoresis............................................................. 82

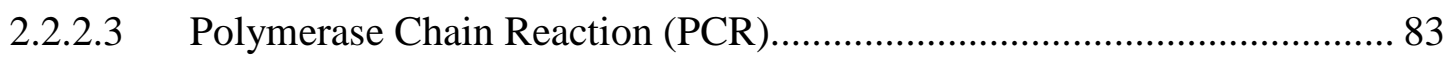

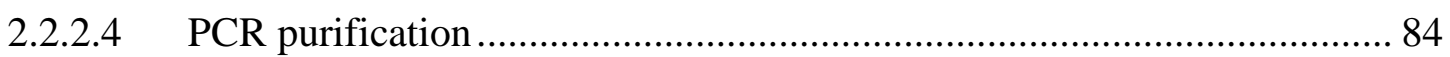

2.2.2.5 Denaturing Gradient Gel Electrophoresis (DGGE) ................................... 84

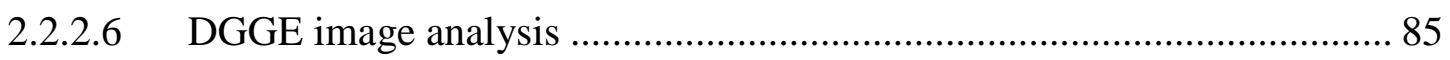

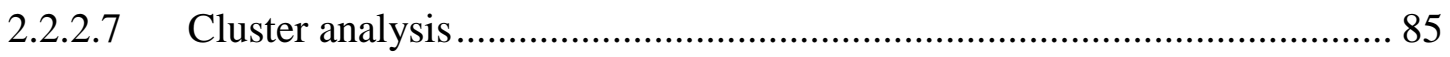

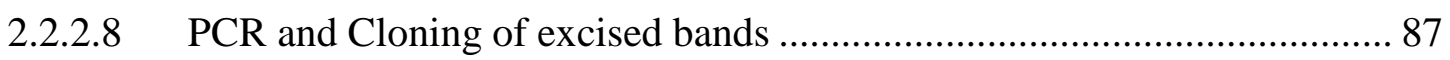

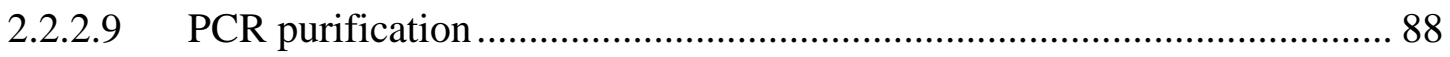

2.2.2.10 Sequencing and sequence reads analysis............................................... 88

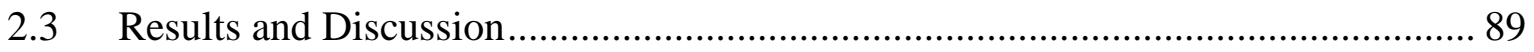

2.3.1 Performance of bench scale-co-digestion with most promising wastes ........... 89

2.3.2 Specific methanogenic activity (SMA) of biomass ........................................... 90

2.3.2.1 SMA against acetate and propionate ....................................................... 90

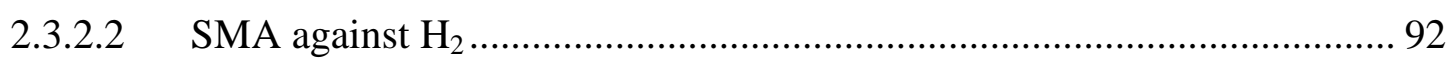

2.3.3 Influence of co-digestion on microbial community structure........................... 93

2.3.3.1 DGGE images of mcrA ……………………..................................... 93

2.3.3.2 Dendrogram of mcrA of biomass from digesters ...................................... 94

2.3.3.3 Principal component analysis (PCA) ..................................................... 96

2.3.4 quantitative polymerase chain reaction (qPCR) .............................................. 98

2.3.5 Relationship between SMA and microbial community structures using DGGE

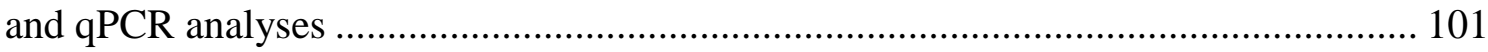

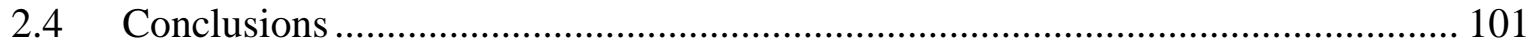

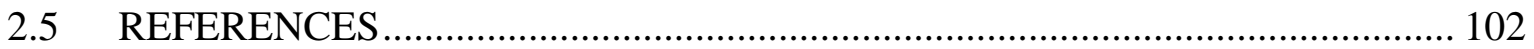

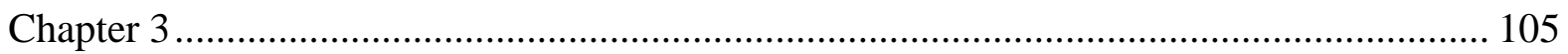

Overall Conclusions, Future Study and Recommendations ............................................... 105

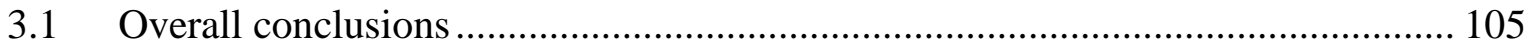

3.2 Future Study and Recommendations................................................................. 106 


\section{LIST OF TABLES}

Table Title Page

$1.1 \quad$ Analysis methods for solid/semisolid and liquid samples ........................................ 16

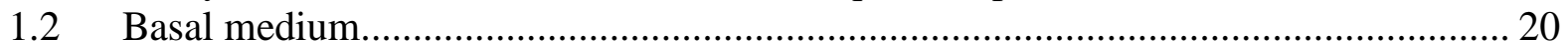

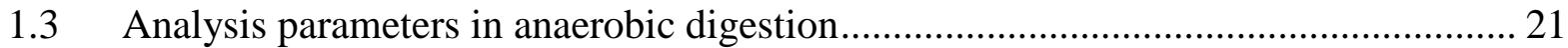

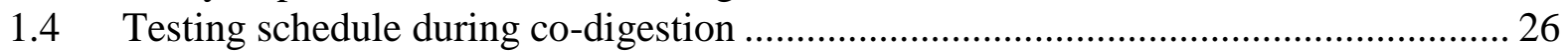

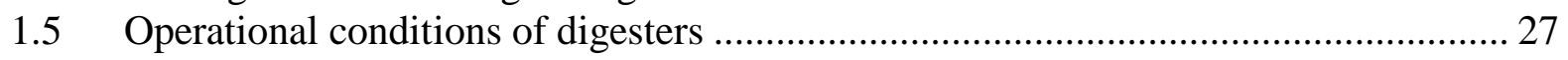

1.6 Waste characteristics and facility descriptions for potential co-digestates.................. 30

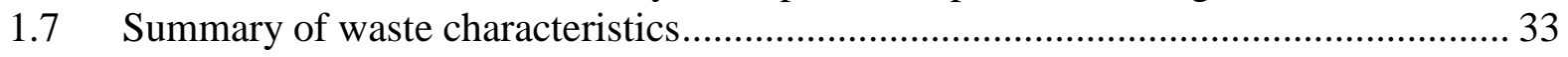

1.8 Methane production due to synergism of co-digestion................................................ 53

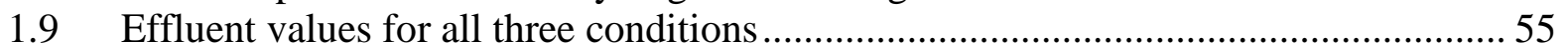

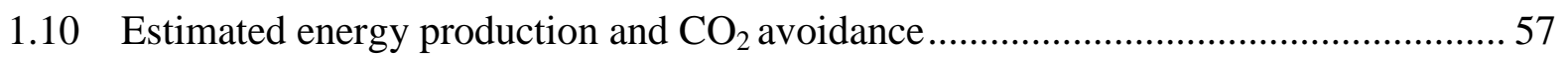

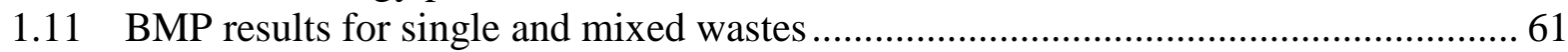

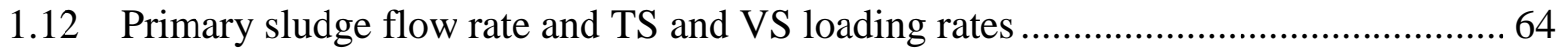

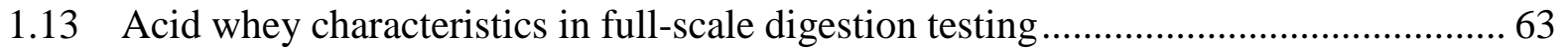

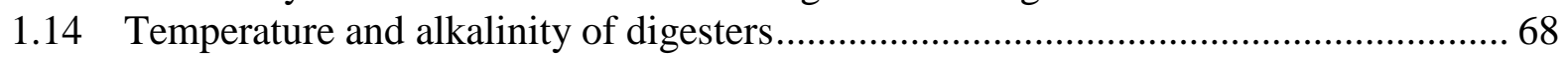

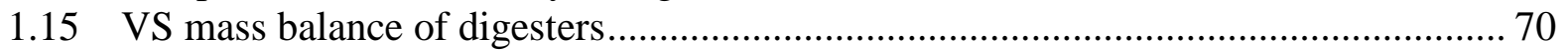

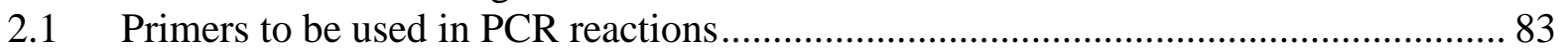

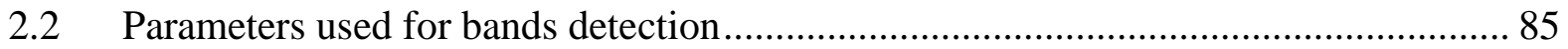

2.3 Operational and steady performance characteristics after co-digestion ...................... 89

2.4 Total DNA, RNA and VSS in the digested biomass (Adapted from Morris, 2011).. 100

A.1 Cost-benefit analysis for promising co-digestates ................................................... 110

A.1 Cost-benefit analysis for promising co-digestates (continued)................................ 111

A.2 Biogas and co-digestates flow rate for full-scale testing ......................................... 117

A.3 Excess methane production calculation due to co-digestion synergistic outcome based

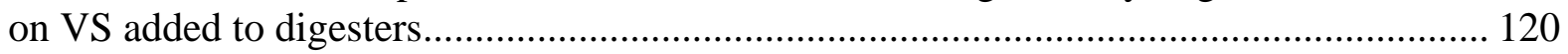

A.4 TS removal efficiency calculation ........................................................................ 120

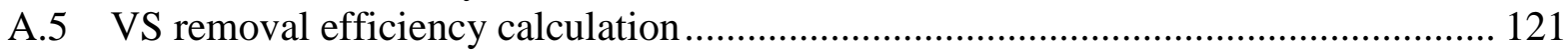

B.1 Optical intensities for detected bands from DGGE gels ........................................... 123

B.2 Gene copy and transcript numbers of the biomass obtained from qPCR and their

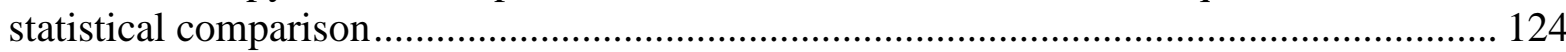




\section{LIST OF FIGURES}

Figure Title Page

1.1 Summary of the anaerobic digestion carbon flow ................................................... 3

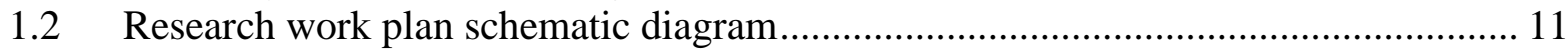

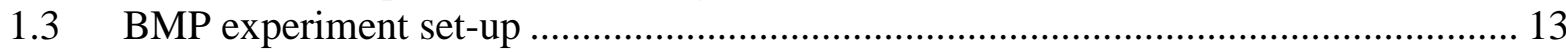

1.4 Schematic diagram of bench-scale anaerobic digester .............................................. 19

1.5 Feed and waste streams at the SSWWRF............................................................... 25

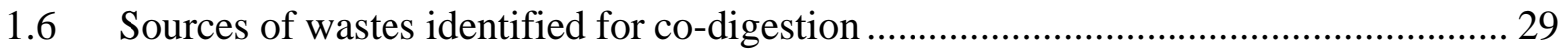

1.7(a) Biochemical methane potential (BMP) results for 22 promising co-digestates .......... 41

1.7(b) Biochemical methane potential (BMP) results for 24 promising co-digestates........... 41

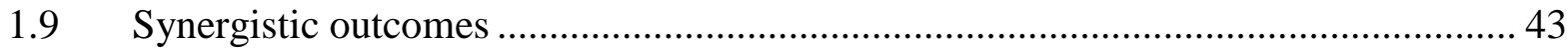

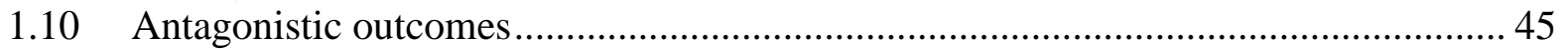

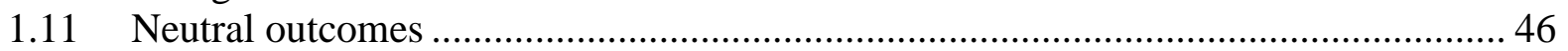

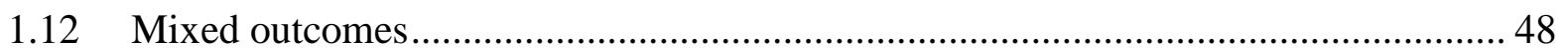

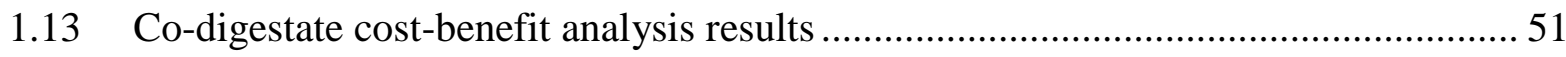

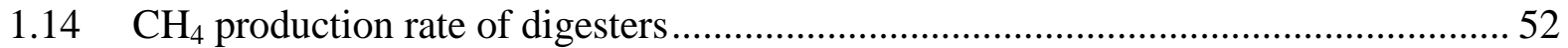

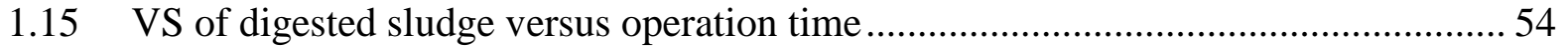

1.16 Effluent $\mathrm{NH}_{3}-\mathrm{N}$ and $\mathrm{TKN}$ concentration under three conditions............................... 55

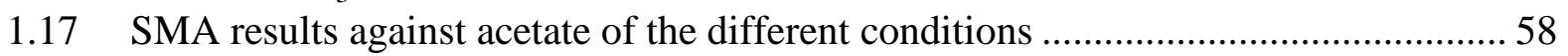

1.18 SMA results against propionate of the different conditions .....................................5 59

1.19 SMA results against $\mathrm{H}_{2}$ of the biomass from the different digesters ........................... 60

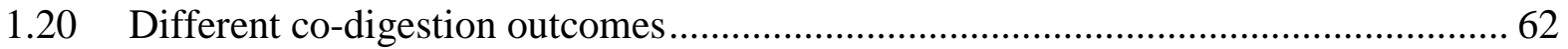

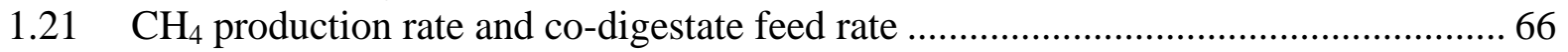

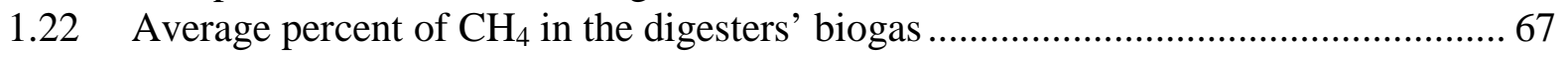

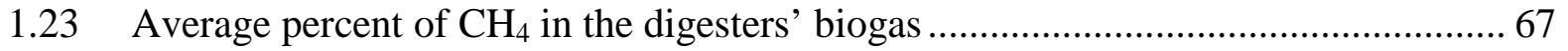

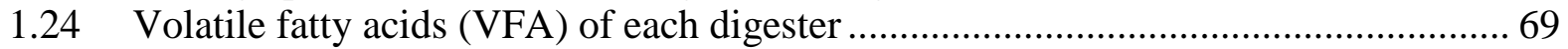

2.1 SMA results against acetate of the different conditions ........................................... 91

2.2 SMA results against propionate of the different conditions ....................................... 91

2.3 SMA results against $\mathrm{H}_{2}$ of the biomass from the different digesters .......................... 92

2.4 DGGE image (a) Before co-digestion and (b) at 8 weeks after co-digestion .............. 94

2.5 Cluster analysis of the samples at 2 weeks after co-digestion .................................... 95

2.6 Cluster analysis of the samples at 8 weeks after co-digestion................................... 95

2.7 Principal component analysis results at 2 weeks after co-digestion ........................... 96

2.8 Principal component analysis results at 8 weeks after co-digestion ........................... 97

2.9 Results of qPCR for the digesters (Adapted from Morris, 2011) ............................... 99

B.1 DGGE image at 2 weeks after co-digestion .......................................................... 123 


\section{Chapter 1 \\ Anaerobic co-digestion for increased renewable energy}

\subsection{Introduction}

World energy demand is rapidly increasing with increasing human population, urbanization and modernization (Asif and Muneer, 2007). Most of a countries' energy is delivered by fossil fuels, which are limited in quantity. Moreover, energy generation from fossil fuels can potentially increase greenhouse gas emissions. Therefore, it is important to find alternative energy production strategies such as a renewable energy. Many attempts to produce renewable energy have been made by researchers. These attempts involve wind energy, solar energy biogas energy and other technologies. Biogas energy from waste is an interesting option since it offers two benefits: energy production and waste treatment. Anaerobic digestion is a proven technology to produce biogas from waste.

\subsubsection{Anaerobic digestion and anaerobic co-digestion}

Anaerobic digestion (AD) is a process for treating organic compounds in wastes and produces biogas. Produced biogas is basically composed of around $65 \%$ methane $\left(\mathrm{CH}_{4}\right)$ and $35 \%$ carbon dioxide $\left(\mathrm{CO}_{2}\right)$ with trace quantities of potentially corrosive hydrogen sulfide and water vapor. $\mathrm{CH}_{4}$ can be burned to produce combined heat and power $(\mathrm{CHP})$ as renewable energy. This process relies on microorganisms that break down complex organic compounds into biogas as an end product in the absence of oxygen. Anaerobic digestion is carried out in a series of four main steps involving different groups of microorganisms: hytrolytic bacteria, acidogenic bacteria, acetogenic 
bacteria and methanogens (Speece 1996; White 2000; Ecke and Lagerkvist, 2000; De Mes et al., 2003). Figure 1.1 summarizes the process. Organic matter can contain long chain polymers including particulate carbohydrates, lipids and proteins. The complex and insoluble polymer cannot penetrate cellular membranes and is not directly consummed by the microorganisms. The first step is called hydrolysis in which the complex organic matter is broken down into soluble organic matter (monomers) containing sugars, amino acids and fatty acids by hydrolytic bacteria. Subsequently, these soluble molecules are converted into fatty acids and alhohols by acidogenic bacteria/fermenting bacteria. During acetogenesis, acetogenic bacteria convert these fatty acids and alcohols into acetate and hydrogen and $\mathrm{CO}_{2}$. In the last step (methanogenesis), methanogens use acetic acid or $\mathrm{CO}_{2}$ and hydrogen to produce $\mathrm{CH}_{4}$ and $\mathrm{CO}_{2}$. In addition to the four main steps in the anaerobic digestion carbon flow (metabolic pathway), there is a linkage between acetic acid and hydrogen and $\mathrm{CO}_{2}$. Hydrogen and $\mathrm{CO}_{2}$ may be converted to acetate by the homoacetogenic bacteria (White, 2000). On the other hand, acetate may be converted to hydrogen and $\mathrm{CO}_{2}$ by acetate oxidizing organisms (Karakashev et al. 2006). Overall, anaerobic digestion carbon flow is a complex pathway (McMahon et al. 2004).

Anaerobic digestion process performance depends on operating parameters such as temperature, mixing, hydraulic retention time (HRT), solid retention time (SRT) as well as digester configuration. Digestion is often operated in the mesophillic range (30 to $38^{\circ} \mathrm{C}$ or 95 to $\left.105^{\circ} \mathrm{F}\right)$. It is also possible to operate in the thermophillic range $\left(50\right.$ to $57^{\circ} \mathrm{C}$ or 122 to $136^{\circ} \mathrm{F}$ (Metcalf and Eddy, 2003). Optimum $\mathrm{pH}$ for methanogenesis is in the range of 6.8-8.3 (Speece, 2008). 


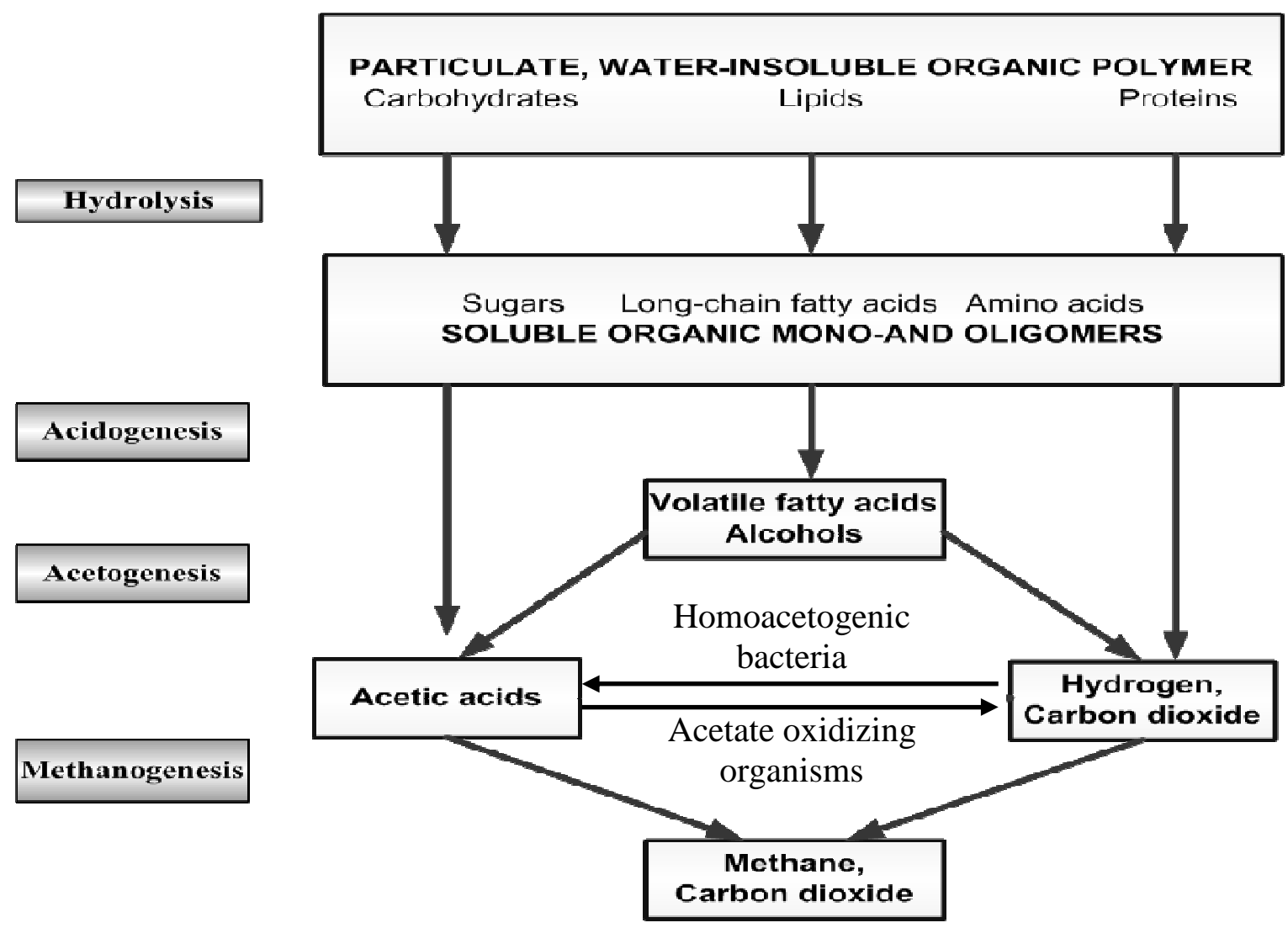

Figure 1.1: Summary of the anaerobic digestion carbon flow

For treating high strength organic pollution, anaerobic treatment is often more cost effective than aerobic treatment. Moreover, energy recovery from $\mathrm{CH}_{4}$ produced, lower operating cost (no aeration required) and the capability of handling higher loading rates are benefits that encourage the use of anaerobic treatment as a sustainable treatment technique.

A modification called "co-digestion" is now used. In co-digestion, a mixture of waste/feedstocks from multiple locations is treated together (Ahring et. al., 1992). In this way, more organic carbon is added to make efficient use of existing digesters to produce more $\mathrm{CH}_{4}$. When various wastes are mixed and co-digested, synergistic, neutral and 
antagonistic outcomes are possible. Before describing these outcomes, advantages and disadvantages of co-digestion are described below.

\subsubsection{Advantages and disadvantage of anaerobic co-digestion}

A significant opportunity exists to increase renewable energy production using existing anaerobic digesters. Use of co-digestion at municipal anaerobic digesters is typically focused on increasing sustainable waste treatment for communities, increased revenue and renewable energy production. Many municipal digesters exist and are distributed around the United States. For example, there are 1455 municipal wastewater treat plants (including 104 plants with combined heat and power installations) in the United States and more than 60 municipal wastewater treatment plants in the state of Wisconsin that have anaerobic digesters (EPA, 2011; Vik, 2003). Furthermore, the biogas already produced is often used for renewable energy for combined heat and power (CHP) applications including electricity generation. Existing municipal digesters have excess capacity and could treat other co-digestates. When multiple co-digestates are properly blended, more organic carbon can be digested at a facility to produce more $\mathrm{CH}_{4}$ and renewable energy.

Increased use of co-digestion can help reduce greenhouse gas (GHG) emissions. GHG emission from materials such as dairy manure that release $\mathrm{CH}_{4}$ to the atmosphere can be reduced by collecting and burning the $\mathrm{CH}_{4}$. Also, the biogas can replace fossilfuel-derived electricity that generates $\mathrm{CO}_{2}$ from sequestered carbon, such as coal. It is estimated that biogas plants in Denmark reduced the country's total 1996 GHG emissions 
by $0.3 \%$ (Maeng et al., 1999). Biomass carbon, such as that in food, ethanol and biodiesel production waste, is primarily derived from $\mathrm{CO}_{2}$ fixed from air; therefore digesting and burning this organic carbon recycles $\mathrm{CO}_{2}$ back to the atmosphere with little or no net increase.

Other advantages of co-digestion are cost-sharing by processing multiple wastes in a single facility, equalization of floating, settling, acidifying wastes through dilution and improved nutrient balance. Others report the optimum C/N/P ratio (on a mass basis) to be 100-128/4/1 (Rizk et al., 2007). Chen et al. (2008) listed an optimum C/N ratio (on a mass basis) of 20 and COD/N ratio (on a mass basis) of 70 . Some co-digestates may have a higher $\mathrm{C} / \mathrm{N}$ ratio, meaning that available nitrogen may not be adequate, and it would be beneficial to add other co-digestates that have a low $\mathrm{C} / \mathrm{N}$ ratio. In this way, codigestion may improve digester performance through better nutrient balance. Moreover, co-digestion can be used to gain revenue such as carbon credits, tipping fees, and renewable energy tax credits in addition to revenue from biogas for electricity and heat. However, there are significant expenses such as transportation as well as digested biosolids handling and disposal costs. It is important to consider these revenue and expense items when selecting promising wastes for co-digestion.

\subsubsection{Disadvantage of anaerobic co-digestion}

There are a few disadvantages of full scale anaerobic co-digestion. Since each waste comes to a wastewater treatment plant from a different location, there could be high conveyance / transportation costs. In some locations, when waste conveyance is not 
possible on a daily basis, a large tank for temporary storage of waste generated and received may be required. When waste has large particles, pretreatment may be required for size reduction before co-digestion. Moreover, when multiple wastes and variable feeds are digested together, there may be the possibility for foaming in the digester.

\subsubsection{Synergism, anatonistic and neutral outcomes}

Anaerobic co-digestion can result in different outcomes including synergism, antagonistic or neutral outcomes depending on waste identity and characteristics. These outcomes can be defined based upon $\mathrm{CH}_{4}$ production that is greater than, less than or the same as that observed when each material is digested alone (Zitomer et al., 2008).

Therefore, anaerobic co-digestion with synergistic waste is gaining increased attention. However, identification of synergistic wastes is challenging since co-digestion outcomes have not been studied for a broad range of wastes. Synergistic outcomes may occur when substrate utilization rate can be increased through optimum nutrient balance of blended wastes. Antagonistic outcomes may result from inhibitory concentrations of toxic substances in one or more wastes. However, other fundamental mechanisms for these outcomes have not been defined. It is important to develop a proper method for investigating these outcomes for engineering applications.

Successful combinations of different types of wastes and wastewater require careful management. Batch anaerobic bioassay techniques have been developed by others as simple and inexpensive procedures to monitor relative biodegradability and possible toxicity of wastes to be treated by anaerobic digestion. There are currently two 
assay tests, (1) biochemical $\mathrm{CH}_{4}$ potential (BMP) and (2) anaerobic toxicity assay (ATA), to identify potential co-digestates for anaerobic co-digestion. Also, these two tests can be used to determine synergistic, neutral and antagonistic outcomes as described in the subsequent part of this Chapter. The BMP and ATA tests are relatively simple bioassays that can be conducted in laboratories without the need for sophisticated equipment.

\subsubsection{Biochemical methane potential (BMP) test}

The BMP is a measure of sample biodegradability (Owen et al., 1979). The BMP test is a screening tool to determine the $\mathrm{CH}_{4}$ volume that can be produced from a waste's short-term, non-steady state digestion. In other words, the BMP is a measure of what fraction of a given wastes' COD can be converted to $\mathrm{CH}_{4}$ anaerobically (Speece, 1996). The assay provides a simple means to monitor relative anaerobic biodegradability of substrates. Uses of the BMP are as follows:

- Assaying the concentration of organic pollutants in a wastewater which can be anaerobically converted to $\mathrm{CH}_{4}$

- Evaluating potential anaerobic process efficiency

- Measuring residual organic pollution amenable to further anaerobic treatment

- Testing for non-biodegradable chemical oxygen demand (COD) remaining after treatment

\subsubsection{Anerobic toxicity assay (ATA) test}

The ATA was developed to determine any toxic effect of a substance or waste on the organisms that convert acetate to $\mathrm{CH}_{4}$ (Owen et al., 1979). These organisms are 
typically considered to be the microbes most sensitive to toxicants in the mixed microbial culture that achieves $\mathrm{CH}_{4}$ production from complex substrates. Like the BMP test, the ATA test is relatively simple. The significant difference between the BMP and ATA assays is that the ATA is supplemented with a high concentration of acetate as well as varying wastewater concentrations, whereas no acetate is added to the BMP system. The ultimate or maximum biogas produced is most important in the BMP test, whereas the initial rate of gas production is of primary interest in the ATA test (Speece, 1996).

\subsubsection{Economic analysis}

BMP and ATA results can be used to help select the most promising wastes for bench-scale testing. However, these tools don't reveal the actual worth of co-digestion. Therefore net cost-benefit analysis should be performed by considering all estimated benefits and costs related to co-digestion. The benefits include revenue from biogasgenerated electricity and heat, carbon credits, tipping fees, renewable energy tax credits and any other benefits that accrue. The costs include transportation and digested biosolids handling costs. It is important to consider all revenue and costs when selecting promising wastes for co-digestion.

\subsubsection{Bench-scale anaerobic co-digestion}

Most previous bench-scale co-digestion studies focused on optimizing process performance by determining blending ratio of co-digestates with municipal sludge. In addition, foaming potential and volatile solids destruction should be observed using bench scale testing before implementing full-scale co-digestion. Previous bench- and pilot-scale studies of co-digestion have been performed using various co-digestates. 
Typical co-digestates combined with municipal sludge include fat, oil and grease (Kabouris et al., 2008; Kabouris et al., 2009), food waste ( Kim et al., 2004; Di Palma et al., 1998; Bjornsson et al., 2000; Edelmann et al., 2000; Lafitte-Toru and Forster, 2000), algae (Cecchi et al., 1996), winery wastewater (Rodriguez et al., 2007), confectionary waste including syrups (Lafitte-Toru and Forster, 2000), cattle manure, fruit and vegetable and poultry waste (Misi and Forster, 2002), slaughterhouse waste including stomach content and dissolved air floatation float (Rosenwinkel and Meyer, 1999), paper mill sludge and organic fraction of municipal solid waste (Einola et al., 2001), wood waste and starch hydrolyzate (Converti et al., 1997) and the organic fraction of municipal solid waste including office paper, newspaper, grass clipping and dog food production waste (Schmit and Ellis, 2001).

\subsubsection{Full-scale-scale anaerobic co-digestion}

There has been some full scale co-digestion testing and implementation conducted in the past two decades. Full-scale thermophilic anaerobic co-digestion of cow manure and oil or waste from protein extraction from bone was reported (Ahring et al., 1992). Fats, oils and grease (FOG) was co-digested with wastewater treatment plant sludge in Oxnard, CA (Alatriste-Mondragon et al., 2006; Bailey, 2006); Lincoln, NE and East Bay Municipal Utilities District, CA (Schater et al., 2007); Redwood and Riverside, CA (Bailey, 2006); Milbrae, CA (Chung, 2007; York, 2009); Watsonville, CA (Cockrell, 2008); and South-Cross Bayou Water Reclamation Facility (WRF) and Pinellas County, FL (Kabouris et. al., 2007, Kabouris et. al., 2009). Most of the full-scale co-digestion studies for municipal anaerobic digesters were performed with addition of FOG. The 
expansion of full-scale co-digestion to other possible co-digestates should be investigated.

\subsubsection{Research hypothesis}

In this study, three hypotheses were considered:

1. Co-digestion of some co-digestates increases biogas production significantly more than predicted by digestion of each co-digestate alone.

2. Co-digestion of some co-digestates increases specific methanogenic activities (SMAs) against acetate, propionate and hydrogen.

3. Co-digestion of acid whey in full-scale demonstrates a synergistic outcome (produces additional $\mathrm{CH}_{4}$ greater than anticipated theoretical $\mathrm{CH}_{4}$ from chemical oxygen demand (COD)).

\subsection{Methodology}

The work described herein was performed to assess anaerobic co-digestion of various wastes with municipal primary sludge as a sustainable energy technology. However, synthetic primary sludge was used for bench-scale testing to avoid the high variability of real primary sludge and potential infection from pathogens from real sludge. High-organic-strength wastes were considered from sources located within 100 miles (160 km) from South Shore Wastewater Reclamation Facility (SSWWRF) in Oak Creek, WI. After the most promising co-digestates were selected for possible full-scale digestion, the capability of the existing equipment at the wastewater treatment plant was considered. 
This study focused on protocols of co-digestate selection for full-scale applications and increased renewable energy. The research work was divided into four parts: (1) identification of promising co-digestates using a market study, (2) identification of at least 5 promising co-digestates using waste characterization and simple economic analysis, (3) determination of performance of bench-scale co-digestion for selected codigestates, and (4) determination of performance of full-scale co-digestion for one of the best co-digestates. The research plan is shown in Figure 1.2.

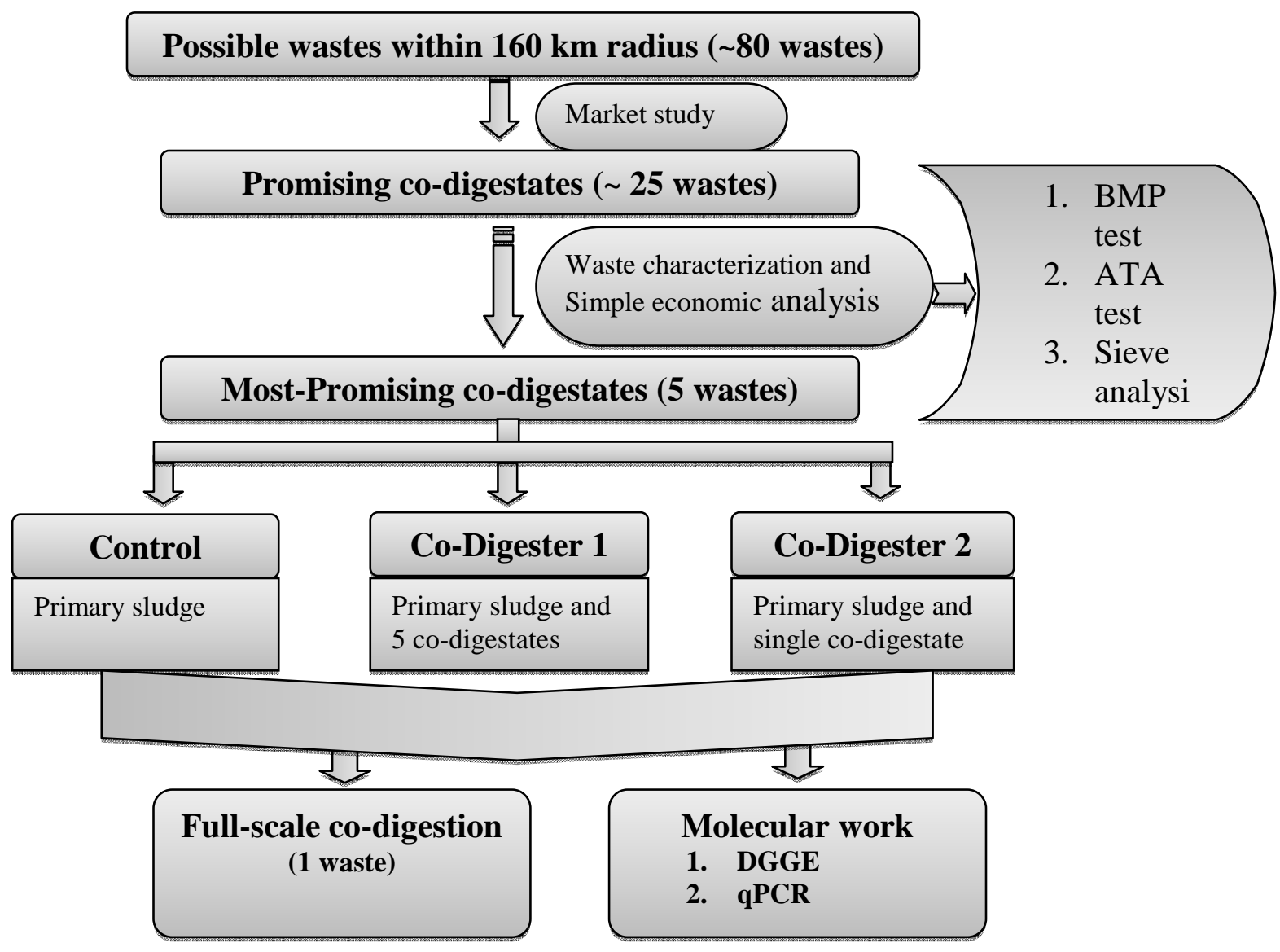

Figure 1.2: Research work plan schematic diagram 


\subsubsection{Preliminary screening}

A market survey was performed primarily to identify high-strength wastes produced within a 160-km radius of the Milwaukee Metropolitan Sewerage District (MMSD) South Shore Wastewater Reclamation Facility (Oak Creek, WI, USA). However, the market study was extended to identify bio-refinery wastes even though the distance to the SSWWRF was more than $160 \mathrm{~km}$. Industries were contacted and questioned using a questionnaire for assessment of potential feedstock to municipal anaerobic digesters. The questionnaire included questions about potential co-digestate identity, quantity and constituent concentrations. For simplicity, a facility contact person was requested to fill out a table which was comprised of the following details:

1. Facility waste stream

2. Facility name

3. Facility address

4. Facility contact person

5. Facility email address and phone number

6. Current disposal method (Landfill, wastewater treatment, land application)

7. Quantity (lb/day) or (gal/day)

8. Organic strength (mg/L VS, mg/L VSS, mg/L COD, mg/L BOD 5 other)

\subsubsection{Identify most promising co-digestates}

After preliminary screening, the promising wastes were sampled and characterized by constituent analyses, BMP, ATA and sieve analysis testing. 


\subsubsection{Biochemical methane potential (BMP) testing}

The BMP protocol of Owen et al. (1979) was used as one of the tools to screen co-digestates in terms of the volume of $\mathrm{CH}_{4}$ produced per unit of waste at $35^{\circ} \mathrm{C}$ and 1 atm. Seed biomass was used from a bench-scale anaerobic digester fed non-fat dry milk and nutrients. All systems were seeded with $30 \mathrm{~mL}$ of biomass. No basal media was added to all systems. Test assay and standard contained approximately $65 \mathrm{mg}$ COD of waste or glucose, respectively, in addition to the biomass, and seed blanks received no waste (see Figure 1.3).

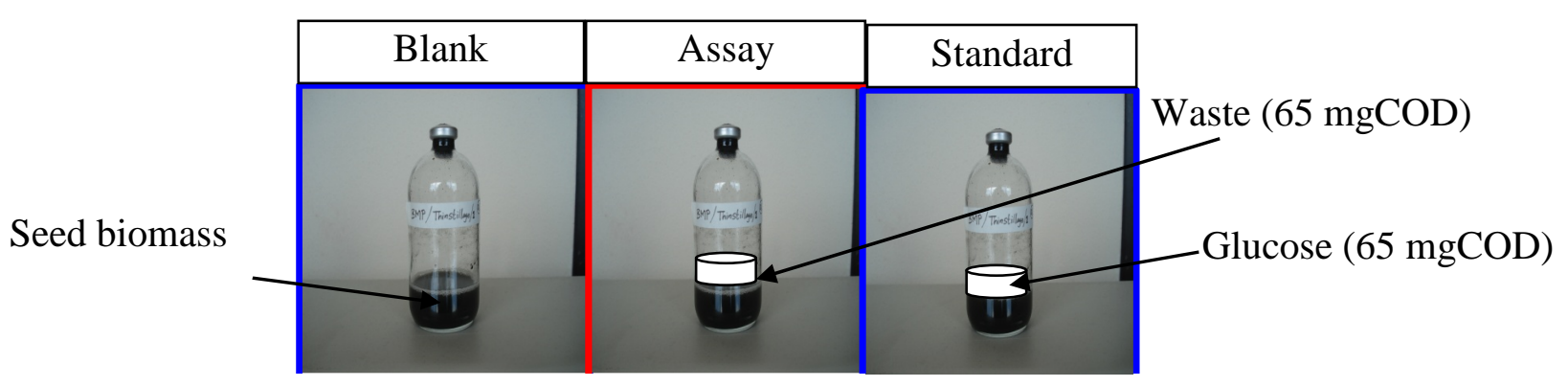

Figure 1.3: BMP experiment set-up

Testing was conducted in 160 -mL serum bottles sparged with oxygen-free gas (7:3 v/v $\mathrm{N}_{2}: \mathrm{CO}_{2}$ ) and sealed with solid, black, butyl rubber stoppers and aluminumcrimped seals. All testing was performed in triplicate at $35^{\circ} \mathrm{C}$ and $150 \mathrm{rpm}$ using an incubator shaker (model C25KC, New Brunswick Scientific, Edison, NJ). The biogas volume produced was measured at ambient pressure and $35^{\circ} \mathrm{C}$ every day using a $100-\mathrm{mL}$ glass syringe with a wetted glass barrel. Syringe content was re-injected into the serum bottle after volume measurement. Headspace $\mathrm{CH}_{4}$ content was measured by gas chromatography (GC). $\mathrm{Net}_{\mathrm{CH}_{4}}$ production was calculated as the total volume of $\mathrm{CH}_{4}$ produced by seed blanks subtracted from the total volume of $\mathrm{CH}_{4}$ produced in test 
systems. BMP was calculated as the net $\mathrm{CH}_{4}$ production divided by the co-digestate $\mathrm{COD}$ or VS added to the serum bottle.

\subsubsection{Anaerobic Toxicity Assay (ATA) testing}

ATA tests were performed to determine the potential inhibitory or stimulatory affect of each waste on maximum $\mathrm{CH}_{4}$ production rate from acetate (Owen et al., 1979). For each assay, different doses of waste $(<12 \mathrm{~g} \mathrm{COD/L})$ were added along with calcium acetate $(10 \mathrm{~g} / \mathrm{L})$ as the main, non-limiting substrate to $50 \mathrm{~mL}$ of biomass. Seed biomass was used from a bench-scale anaerobic digester fed non-fat dry milk and nutrients. Testing was conducted in 160-mL serum bottles sparged with oxygen-free gas $(7: 3 \mathrm{v} / \mathrm{v}$ $\mathrm{N}_{2}: \mathrm{CO}_{2}$ ) and sealed with solid, black, butyl rubber stoppers aluminum-crimped seals. All testing was performed in triplicate at $35^{\circ} \mathrm{C}$ and $150 \mathrm{rpm}$ using an incubator shaker (model C25KC, New Brunswick Scientific, Edison, NJ). The biogas volume produced was measured at ambient pressure and temperature of $35^{\circ} \mathrm{C}$ every day using a $100-\mathrm{mL}$ glass syringe with a wetted glass barrel. The maximum $\mathrm{CH}_{4}$ production rate was determined by linear regression using the initial portion of a graph of cumulative $\mathrm{CH}_{4}$ production versus time. A dose-response curve was prepared by plotting the maximum $\mathrm{CH}_{4}$ production rate versus waste dose. For inhibitory wastes, the concentration causing a $50 \%$ decrease in $\mathrm{CH}_{4}$ production rate ( $\mathrm{IC}_{50}$ concentration) was determined from a graph of $\mathrm{CH}_{4}$ production rate versus waste dose. 


\subsubsection{Sieve analysis}

There was a concern that large solid particles in the waste could potentially damage pumps and other equipment and settle in the unmixed waste storage tank and the digester at the treatment plant. Therefore it was important to determine particle size distribution of each waste. This test was performed using a standard sieve analysis method. For sieve analysis, sieves with minimum opening size of 0.053mm (No 270) and maximum opening size of $4.75 \mathrm{~mm}$ (No 4) were used. In this test, each waste was allowed to pass through the selected, stacked sieves. The number of sieves used in these tests was in the range of 4 to 6 because 4 sieves were enough for some wastes in which most of the particles (> 99\%) passed through all the sieves. The total dry mass of retained particles on each sieve was measured. Percent (\%) retained and \% passing were also calculated. Finally, a plot of $\%$ passing versus sieve opening size was constructed for each waste (i.e., a "sieve curve"). The $\mathrm{d}_{10}$ (sieve opening size passing $10 \%$ of the material), $\mathrm{d}_{50}$ and $\mathrm{d}_{90}$ were calculated from the plots.

\subsubsection{Analytical methods}

Chemical oxygen demand (COD), soluble chemical oxygen demand (SCOD), total solids (TS), volatile solids (VS), ammonia nitrogen $\left(\mathrm{NH}_{3}-\mathrm{N}\right)$, total Kjeldahl nitrogen (TKN), total phosphorous and alkalinity concentrations were measured using standard methods (APHA et al., 1998). Fats, oils and grease (FOG) was measured using EPA (1999). The $\mathrm{pH}$ was measured using a glass electrode and meter. Biogas $\mathrm{CH}_{4}$ content and volatile fatty acid (VFA) concentrations were determined by gas chromatography (Series 7890A GC system, Agilent Technologies, Santa Clara, CA, 
USA) with a thermal conductivity detector (TCD) and flame ionization detector (FID), respectively. In waste characterization, total phosphorus, $\mathrm{NH}_{3}-\mathrm{N}$, TKN and FOG were analyzed by Mike Dollhopf, Lab Manager of the Water Quality Center, Marquette University.

\subsubsection{Metals analyses}

The samples were sent to Northern Lake Service, Inc., 400 North Lake, Crandon, WI for metals analyses. The methods for digesting samples for metals analysis are presented in Table 1.1. Methods of digestion were different for solid/semi-solid samples and liquid samples. The brewery grain, paunch, dried manure, float, flavorings yeast, yeast centrate, sprout, wet distillers grain, syrup, whole stillage, thin stillage, waste rice, waste noodles, mustard, metal cutting fluids waste, oil and hydraulic fluids, packaging waste and white waste were in the solid/semisolid waste category. The acid whey, brewery yeast, trube, cookie waste, soap, confectionary waste, boiler cleaning waste and can crushing waste were in the liquid waste category.

Table 1.1: Analysis methods for solid/semisolid and liquid samples

\begin{tabular}{|l|c|c|c|}
\hline \multirow{2}{*}{ Metals } & \multicolumn{2}{c|}{ Digestion via } & \multirow{2}{*}{ Instruments } \\
\cline { 2 - 3 } & Solid/semisolid & Liquid & \\
\hline Arsenic v & SW846 7060 & SM 3113-B 19ed & GFAA \\
\hline $\begin{array}{l}\text { Cadmium, Chromium, } \\
\begin{array}{l}\text { Copper,Lead, Molybdenum, } \\
\text { Nickel, Potassium, Silver, Zinc }\end{array}\end{array}$ & SW846 6010 & EPA 200.7 & $\begin{array}{c}\text { ICP-MS, Agilent } \\
7700\end{array}$ \\
\hline Mercury & SW846 7470A & EPA 245.1 & Cold Vapor \\
\hline Selenium & SW846 7740 & SM 3113-B 19ed & GFAA \\
\hline
\end{tabular}

GFAA: Graphite Furnace Atomic Absorption Spectrophotometry

ICP-MS: Inductively Coupled Plasma-Mass Spectroscopy

SW846: Test Methods for Evaluating Solid Waste Physical/Chemical Methods published by Environmental Protection Agency (EPA)

SM 3113: Standard Method for metal analysis in water and wastewater published by EPA 


\subsubsection{Economic analysis}

A simple cost-benefit analysis was performed for co-digestates. The estimated net worth of each co-digestate was calculated as the sum of the estimated value of $\mathrm{CH}_{4}$ produced (0.21 United State Dollar (USD) $\left./ \mathrm{m}^{3} \mathrm{CH}_{4} @ 35^{\circ} \mathrm{C}\right), \mathrm{GHG}$ avoided $(0.003$ USD/kg CO $\mathrm{CO}_{2}$ ) and treatment charges (0.28 USD/kg COD and $0.28 \mathrm{USD} / \mathrm{kg}$ TSS) less the sum of waste conveyance $\left(0.16 \mathrm{USD} / \mathrm{m}^{3}-\mathrm{km}\right)$ and solids handling and disposal $(0.110$ USD/dry TS kg). The $\mathrm{CO}_{2}$ avoidance was estimated assuming fuel switching from bituminous coal (emission factor $\left.=0.088 \mathrm{~kg} \mathrm{CO}_{2} / \mathrm{MJ}\right)$. The emission factor for bio $\mathrm{CH}_{4}$ was assumed to be negligible since the $\mathrm{CO}_{2}$ emitted was assumed to be originally fixed from the atmosphere. The unit GHG emission credit value was estimated from the average daily closing price of 2003 -vintage $\mathrm{CO}_{2}$ credits on the Chicago Climate Exchange. Unit treatment fees were estimated based on current municipal waste treatment fees charged by municipalities in and near Milwaukee, Wisconsin. The waste $\mathrm{BOD}_{5}$ concentration was estimated to be $50 \%$ of the measured COD concentration. Waste conveyance unit cost was estimated from tanker truck contract costs after discussion with regional trucking companies. Solids handling and disposal unit cost (E) was estimated after discussion with operators of various wastewater treatment plants. A volatile solids reduction value of $50 \%$ was assumed; therefore, solids to be disposed of were assumed to be composed of half of the waste volatile solids and all of the inert solids. $\mathrm{A} \mathrm{CH}_{4}$ heat content $(\mathrm{G})$ of $35 \mathrm{MJ} / \mathrm{m}^{3} \mathrm{CH}_{4}$ at $35^{\circ} \mathrm{C}$ was employed.

Subsequently, the selected most promising wastes were co-digested in the bench-scale digesters. 


\subsubsection{Performance of bench-scale anaerobic digesters}

Performance of co-digestion was investigated using pairs of bench-scale digesters under three conditions (Control, Co-Digester 1 and Co-Digester 2) based on biogas production, percent $\mathrm{CH}_{4}$ content, total and individual VFA and TS and VS destruction. In addition, foaming potential and any synergistic outcome were also observed as an indicator of digester performance.

\subsubsection{Anaerobic digester set-up}

Six laboratory-scale anaerobic digesters were fabricated using a transparent acrylic cylinder of 14-cm internal diameter and 30-cm height. Both ends were sealed by an acrylic plate. Each digester had an approximate total volume of $4.5 \mathrm{~L}$ and working liquid volume of 2.5 L. Magnetic mixing was provided to achieve completely mixing in the digester. Each digester was provided with three ports: one for feeding the sludge, a second for withdrawal of digested biosolids, and one for biogas collection. The biogas generated during digestion was collected in a 10-L polyvinyl fluoride film (PVF) gas sampling bag. A schematic diagram of the bench-scale anaerobic digesters is given in Figure 1.4. 


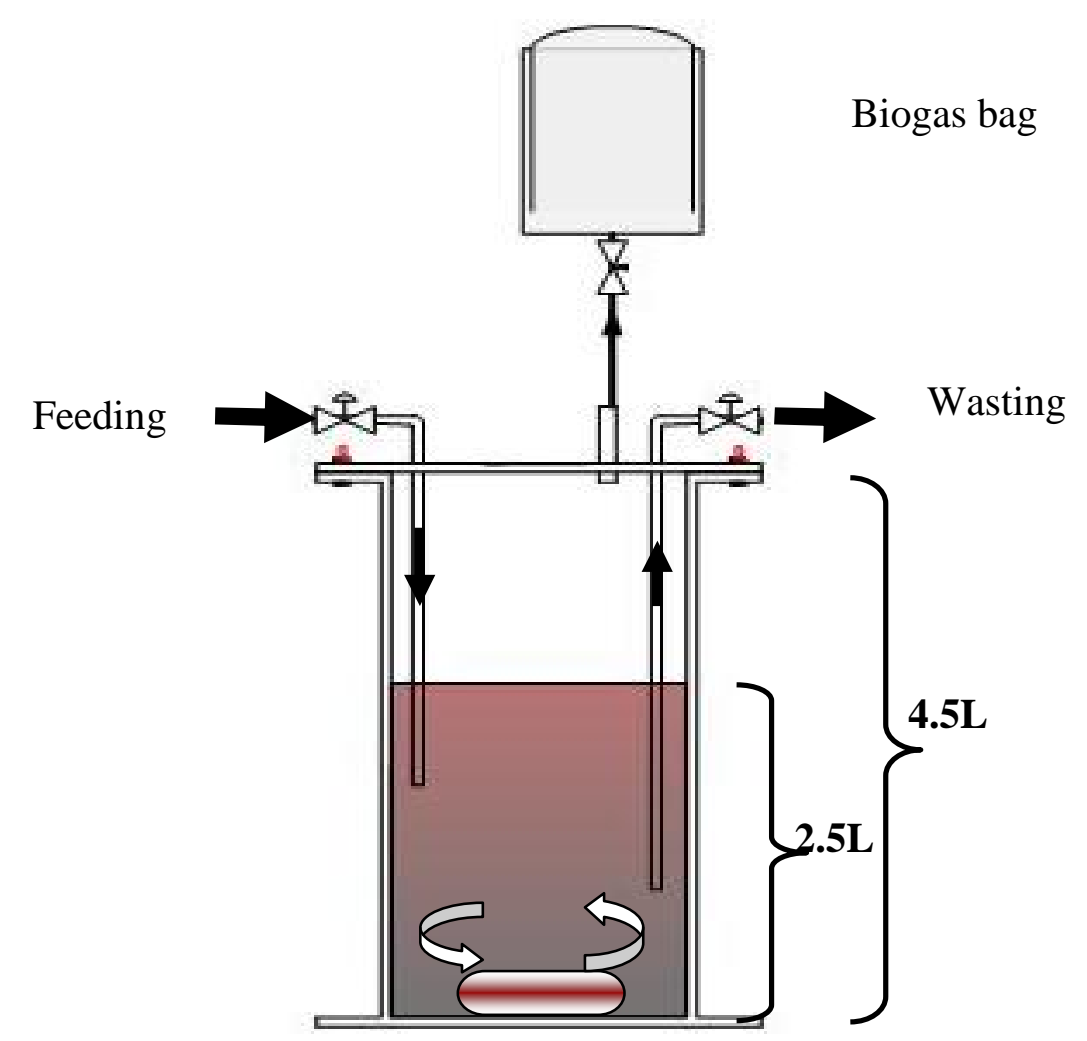

Figure 1.4: Schematic diagram of bench-scale anaerobic digester

\subsubsection{Digester start-up and operation}

All digesters (R1, R2, R3, R4, R5, and R6) were initially seeded with biomass from a full-scale anaerobic digester at SSWWRF. Right after inoculation, headspace in the digesters was sparged with oxygen-free gas containing $30 \% \mathrm{CO}_{2} / 70 \% \mathrm{~N}_{2}$. The digesters were kept under continuously mixed condition using magnetic stirrers (150 $\mathrm{rpm})$ in a temperature-controlled room $\left(35^{\circ} \mathrm{C}\right)$. During the first two days, digesters were kept without feeding. However, biogas production and $\mathrm{pH}$ were monitored. Digesters were operated with daily wasting and feeding (semi-continuous mode) at a solids retention time (SRT) of 15 days. Synthetic primary sludge $(\mathrm{TS}=2.9 \%$ and VS $=2.4 \%$ ) contained a mixture of organic (12\% fat, $26 \%$ protein $5 \%$ fiber) and inorganic solids 
(Natural Choice Dog Food, NutroProducts, Inc., City of Industry, CA, USA) and anaerobic basal medium (see Table 1.2).

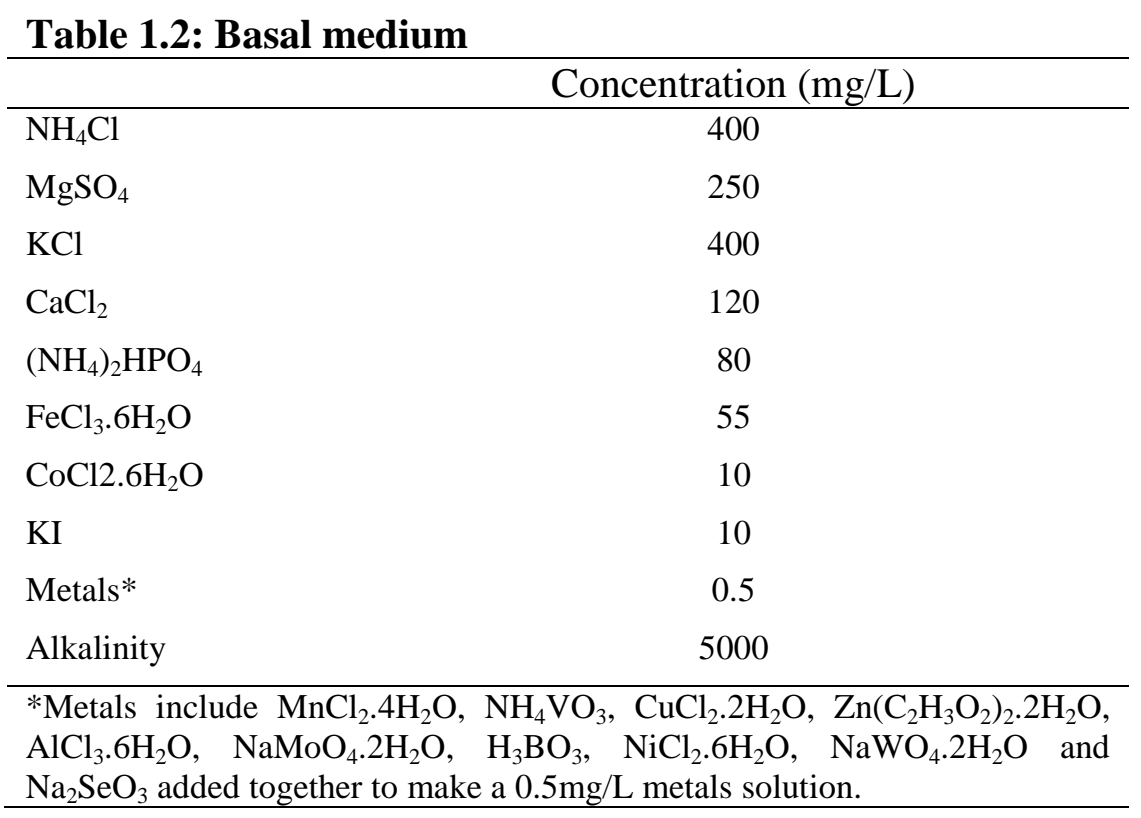

The volume of biogas produced was measured by forcing the collected biogas through a wet test gas meter (every two days after wasting and feeding). The Control (R1 and R2), Co-Digester 1(R3 and R4), and Co-Digester 2(R5 and R6) systems were fed with synthetic primary sludge for the first 55 days (>3 SRTs).

After Day 55, Co-Digester 1 systems were fed with a mix of 5 of the most promising co-digestates in addition to synthetic primary sludge. Co-Digester 2 systems were fed with synthetic primary sludge and the most promising co-digestate. After Day 55, co-digester 1 systems (R3 and R4) were fed the following five most promising codigestates (described in Table 1.6), which were identified through simple economic analysis, in addition to synthetic primary sludge: float $(3.1 \mathrm{~mL} / \mathrm{d}, 0.52 \mathrm{gCOD} / \mathrm{d})$, can 
crushing waste $(2.8 \mathrm{~mL} / \mathrm{d}, 0.22 \mathrm{gCOD} / \mathrm{d})$, thin stillage $(4.9 \mathrm{~mL} / \mathrm{d}, 0.76 \mathrm{gCOD} / \mathrm{d})$, flavorings yeast $(1 \mathrm{~mL} / \mathrm{d}, 0.26 \mathrm{gCOD} / \mathrm{d})$, and acid whey $(3.7 \mathrm{~mL} / \mathrm{d}, 0.54 \mathrm{gCOD} / \mathrm{d})$. CoDigester 2 systems (R5 and R6) were fed with synthetic primary sludge and flavorings yeast waste $(4 \mathrm{~mL} / \mathrm{d}, 1.05 \mathrm{gCOD} / \mathrm{d})$ which was shown to have synergistic affects in previous work (Zitomer et al., 2008). Control systems were continuously fed with only synthetic primary sludge. The loading rates of individual co-digestates to bench-scale anaerobic digesters were selected based on the actual full-scale co-digestate volumes produced and the full-scale digester volume at the SSWWRF. This loading ratio may or may not be optimum. The analytical frequency of parameters is presented in Table 1.3.

Table 1.3: Analysis parameters in anaerobic digestion

\begin{tabular}{|l|c|}
\hline \multicolumn{1}{|c|}{ Parameter } & Frequency \\
\hline Biogas production & $1 / 2$ days \\
\hline Biogas composition & $2 /$ week \\
\hline Individual and total VFA & $2 /$ week \\
\hline Soluble chemical oxygen demand (SCOD)* & $2 /$ week \\
\hline pH* $^{*}$ & $7 /$ week \\
\hline Alkalinity & $2 /$ week \\
\hline TS $^{*}$ & $2 /$ week \\
\hline VS $^{*}$ & $2 /$ week \\
\hline
\end{tabular}

*- parameters were also measured for each feed.

All digesters were operated until quasi-steady state was reached. The quasi steady state was reached either when the effluent characteristics did not vary more that $10 \%$ or after 3 SRTs of operation time (i.e., 45 days). After quasi-steady state, $\mathrm{NH}_{3}$, TKN, total suspended solids (TSS), volatile suspended solids (VSS), and total soluble organic carbon (TOC) concentrations were measured using standard methods (APHA et al., 1998) for at least 5 measurements. 


\subsubsection{Specific methanogenic activity}

The digester performance or "activity" of microbial cultures was determined using SMA tests of biomass samples against acetate, propionate and $\mathrm{H}_{2}$ according to standard methods (Angelidaki et al. (2007) for acetate and propionate; Coates et al. (2005) and Coates et al. (1996) for $\mathrm{H}_{2}$ ).

Assays were conducted in triplicate at $35^{\circ} \mathrm{C}, 150 \mathrm{rpm}$ using an incubator shaker (model C25KC, New Brunswick Scientific, Edison, NJ). All assays were performed under anaerobic conditions in 160-ml serum bottles. The VS concentration of the biomass was measured at the beginning of activity tests.

\subsubsection{SMA against acetate and propionate}

Fifteen mL (140-180 mg VS) and $25 \mathrm{~mL}$ (240-300 mgVS) of biomass were used in acetate and propionate activity tests, respectively. The final total volume of the assay was kept at $30 \mathrm{~mL}$ by adding the appropriate amount of basal media. Bottles were sparged with oxygen-free gas $\left(7: 3 \mathrm{v} / \mathrm{v} \mathrm{N}_{2}: \mathrm{CO}_{2}\right)$, closed with solid, black, butyl rubber septa and incubated. Approximately 3 days were allowed for degassing from residual $\mathrm{COD}$ in the biomass. $\mathrm{CH}_{4}$ content in the headspace was measured using gas chromatography (GC). Substrates were injected through the septum using a syringe and needle to achieve a calcium acetate concentration of $12 \mathrm{~g} / \mathrm{L}$ and a calcium propionate concentration of $3.4 \mathrm{~g} / \mathrm{L}$. The biogas volume produced was measured at ambient pressure and $35^{\circ} \mathrm{C}$ every day using a 10 - or $100-\mathrm{mL}$ (depending upon gas production) glass syringe with a wetted glass barrel. The syringe content was re-injected into the serum 
bottle after volume measurement. Headspace $\mathrm{CH}_{4}$ content was measured by GC at the end of testing.

For acetate and propionate activities, maximum $\mathrm{CH}_{4}$ production rate $(\mathrm{mL}$ $\mathrm{CH}_{4} /$ day) was determined by linear regression of the initial, linear portion of a plot of cumulative $\mathrm{CH}_{4}$ production versus time. SMA values $\left(\mathrm{mL} \mathrm{CH}_{4} / \mathrm{g}\right.$ VS-day) were calculated by dividing maximum $\mathrm{CH}_{4}$ production rate values by average VS mass.

\subsubsection{SMA against $\mathrm{H}_{2}$}

A sample of 8 to $12 \mathrm{mg}$ VS of biomass was used in hydrogenotrophic activity tests. The final total volume of the assay was kept at $30 \mathrm{~mL}$ by adding the appropriate amount of basal media. Bottles were sparged with oxygen-free gas $\left(7: 3 \mathrm{v} / \mathrm{v} \mathrm{N} \mathrm{N}_{2}: \mathrm{CO}_{2}\right)$, closed with solid, black, butyl rubber septa and incubated. Then, 3 days were allowed for degassing from residual COD in the biomass. Subsequently, $100 \mathrm{~mL}$ of an $\mathrm{H}_{2}$ and $\mathrm{CO}_{2}$ gas mixture (at a ratio of 1:4, v/v) at ambient pressure and temperature was injected through the septum using a syringe and needle; then the bottles were incubated. Bottle headspace volume was measured by inserting the needle of a glass syringe with wetted barrel at ambient pressure and at $35^{\circ} \mathrm{C}$ twice a day for 7 days. Syringe content was reinjected into the serum bottle after volume measurements.

For hydrogenotrophic activity, the volume of $\mathrm{H}_{2}: \mathrm{CO}_{2}$ gas utilized was calculated as from the decrease in the gas volumes in the assay plus the gas volume produced from endogenous control bottles at the given period of time. $\mathrm{CH}_{4}$ production was estimated as 
the volume of $\mathrm{H}_{2}: \mathrm{CO}_{2}$ gas utilized divided by 4 based upon the stoichiometry of $\mathrm{CH}_{4}$ production from $\mathrm{H}_{2}$ and $\mathrm{CO}_{2}\left(1 \mathrm{~mol} \mathrm{CH}_{4}\right.$ produced from every 4 mols $\mathrm{H}_{2}$ and $1 \mathrm{~mol}$ of $\left.\mathrm{CH}_{4}\right)$. Maximum $\mathrm{CH}_{4}$ production rate $\left(\mathrm{mL} \mathrm{CH}_{4} /\right.$ day) was determined by linear regression of the initial, linear portion of a plot of cumulative $\mathrm{CH}_{4}$ production versus time. SMA values ( $\mathrm{mL} \mathrm{CH}_{4} / \mathrm{g}$ VS-day) were calculated by dividing maximum $\mathrm{CH}_{4}$ production rate values by average VS mass.

\subsubsection{Co-Digestion with synergistic, antagonistic and neutral outcomes}

A series of BMP tests (13 tests) were performed to determine if co-digestion of different combinations of selected wastes resulted in synergistic, antagonistic or neutral outcomes. The most promising wastes ( 5 wastes) which were co-digested in the benchscale Co-Digester 1 systems and one of the antagonistic wastes (metal cutting fluid) were used for BMP testing with synthetic primary sludge. BMP testing was conducted for each waste alone and together with synthetic primary sludge (1:1 COD basis). All BMP tests were conducted using the procedure described in Section 1.2.2.1.

\subsubsection{Full-Scale co-digestion testing at SSWWRF}

The most promising waste (acid whey) was co-digested with municipal wastewater sludge (primary sludge) in five operating anaerobic digestion tanks (named D6, D8, D10, D11 and D12) at the SSWWRF. The total volume of the five tanks was 12 million gallons (MG). Tanks D6 and D8 were 1.5 MG each, whereas tanks D10, D11 and D12 were $3 \mathrm{MG}$ each. The waste was transported using tanker trucks that could contain a 
maximum of 5500 gallons based on transportation weight limits, then stored in an existing 80,000 L tank at the treatment plant and pumped using a metering pump (model 23H1-K20Z-2131, Chemtron, Inc.) to the feed line to all of the digesters. A maximum of 27,500 gallons ( 5 truckloads) per week of the acid whey was fed at an average rate of 10.2 liters per minute over 61 days. Digester stability/operations, volatile solids removal and $\mathrm{CH}_{4}$ production during co-digestion were compared to those observed during a previous 60-day period when only wastewater sludge was digested (control period) and a 50-day period from the time when acid whey feeding was stopped (post co-digestion period). The primary sludge fed to the digesters was combination of primary sludge from the Jones Island Wastewater Reclamation Facility (JIPS) and SSWERF primary sludge (SSPS). A schematic diagram of feed and waste streams at SSWWRF is given in Figure 1.5 .

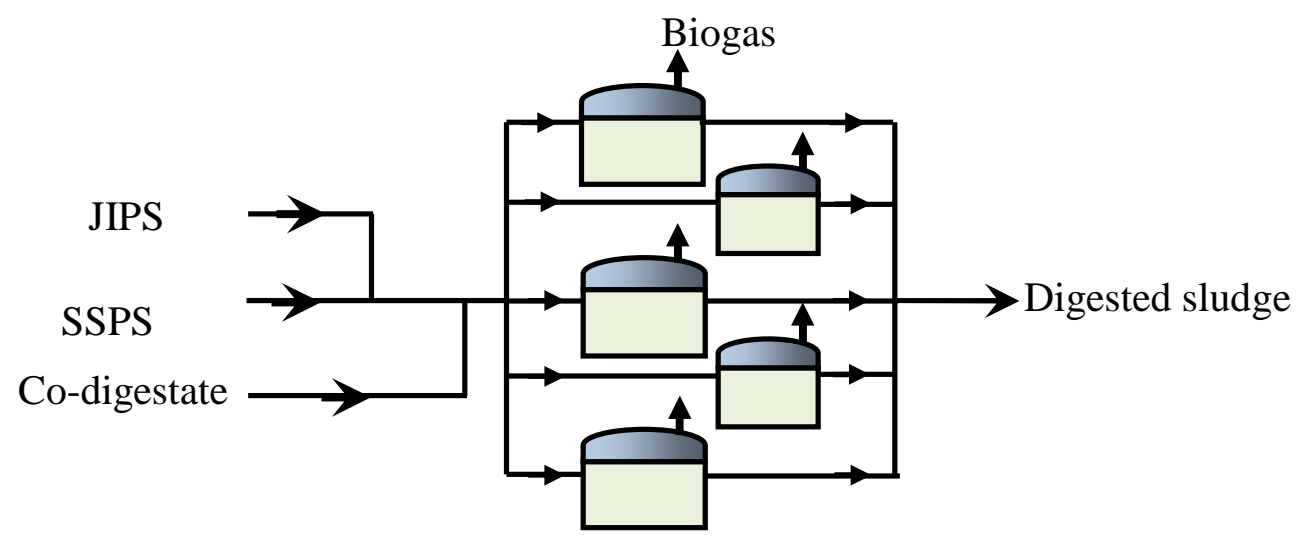

Figure 1.5: Feed and waste streams at the SSWWRF 


\subsubsection{Sampling and analysis}

Sampling frequency and parameters analyzed are listed in Table 1.4. Samples for $\mathrm{COD}, \mathrm{NH}_{3}-\mathrm{N}$ and $\mathrm{TKN}$ analysis were preserved by $\mathrm{H}_{2} \mathrm{SO}_{4}$ immediately after samples were collected. Total daily biogas volume (summed value) from all five digesters was measured using exiting gas meters. $\mathrm{CH}_{4}$ content of biogas was measured once a week.

Table 1.4: Testing schedule during co-digestion ${ }^{1,2,3}$

\begin{tabular}{|c|c|c|c|c|c|}
\hline Parameters & JISS & SSPS & $\begin{array}{c}\text { Digested } \\
\text { sludge }\end{array}$ & Co-digestate & Frequency \\
\hline Flow rate & $\mathrm{x}$ & $\bar{x}$ & $\bar{x}$ & $\mathrm{x}$ & $\begin{array}{l}\text { daily } \\
\end{array}$ \\
\hline Duration of flow & $\mathrm{x}$ & $\mathrm{x}$ & $\mathrm{x}$ & $\mathrm{x}$ & daily \\
\hline $\mathrm{pH}$ & $\mathrm{x}$ & $\mathrm{x}$ & $\mathrm{x}^{* *}$ & $\mathrm{x}$ & daily \\
\hline TS & $\mathrm{x}$ & $\mathrm{x}$ & $\mathrm{x}$ & $\mathrm{x}$ & 1/week \\
\hline VS & $\mathrm{x}$ & $\mathrm{x}$ & $\mathrm{x}$ & $\mathrm{x}$ & 1/week \\
\hline Total VFA & $\mathrm{x}$ & $\mathrm{x}$ & $\mathrm{x} * *$ & $\mathrm{x}$ & 1/week \\
\hline COD & - & - & $\mathrm{x}$ & $\mathrm{X}^{*}$ & 2/week \\
\hline $\mathrm{NH}_{3}-\mathrm{N}$ & - & - & $\mathrm{x}$ & $\mathrm{x}^{*}$ & 2/week \\
\hline TKN & - & - & $\mathrm{x}$ & $\mathrm{x}^{*}$ & 2/week \\
\hline Alkalinity & - & - & $\mathrm{x}^{* *}$ & - & 1/week \\
\hline Temperature & - & - & $\mathrm{x}^{* *}$ & - & daily \\
\hline
\end{tabular}

$\mathrm{X}=$ measurement/analysis was performed

${ }^{1}$ All samples are weekly composite sample unless otherwise noted

$2 *$ two grab samples

$3 * *$ measured for each digester separately

The operational conditions during three periods (Control, Co-Digestion and Post Co-Digestion) are presented in Table 1.5. The average COD of acid whey was $59300 \pm$ $7400 \mathrm{mg} / \mathrm{L}$. 
Table 1.5: Operational conditions of digesters

\begin{tabular}{lccc}
\hline Paramerters & Control & $\begin{array}{c}\text { Co- } \\
\text { Digestion }\end{array}$ & $\begin{array}{c}\text { Post Co- } \\
\text { Digestion }\end{array}$ \\
\hline SRT (days) & 22 & 20 & 22 \\
Average primary sludge loading rate (gTS/L-day) & 1.25 & 1.48 & 1.23 \\
Average primary sludge loading rate (gVS/L-day) & 0.92 & 0.99 & 0.95 \\
Average acid whey flow rate (L/min) & 0 & 10.21 & 0 \\
Average acid whey loading rate (g COD /L-day) & 0 & 0.019 & 0 \\
\hline
\end{tabular}

\subsubsection{Mass balance}

A mass balance of VS for the full-scale anaerobic digesters was calculated. This mass balance was used to calculate the $\mathrm{CH}_{4}$ yield per unit mass of VS destroyed.

\subsubsection{Statistical analyses}

All statistical analyses were performed using ANOVA standard software (Statistics 18, SPSS Inc., Chicago, IL USA).

\subsection{Results and Discussion}

The results and discussion of this chapter are described under the following subsections: market study; identify most promising co-digestates; performance of benchscale co-digesters; specific methanogenic activities; synergistic, antagonistic and neutral outcomes; and performance of full-scale co-digesters.

\subsubsection{Market study}

There were 81 wastes from 54 facilities identified during the market survey. The sources of wastes are presented in Figure 1.6. Other wastes included algae removed from 
lakefront areas, zoo animal waste, and soap production wastes. More than $50 \%$ of wastes were identified as food production wastes (see Figure 1.6 a). The main food production wastes were meat products, flavorings, frozen foods, dairy/cheese and snack foods (see Figure $1.6 \mathrm{~b}$ ). The maximum distance between the source of each waste and SSWWRF was $16 \mathrm{~km}$ for $20 \%$ of wastes, $48 \mathrm{~km}$ for $39 \%$ of wastes, $80 \mathrm{~km}$ for of $52 \%$ wastes and $160 \mathrm{~km}$ for $100 \%$ of wastes. However, one of wastes, Fischer-Tropsch (FT) reactor condensate waste, was identified as an interest even though it was at a distance of 1500 $\mathrm{km}$. This was included since it is of special interest as a biorefinery waste..

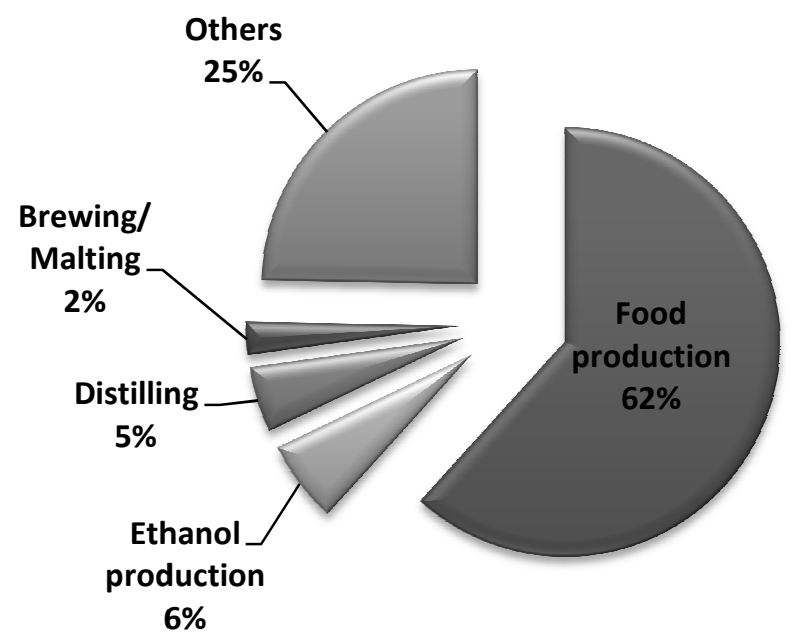

(a) All wastes tested 


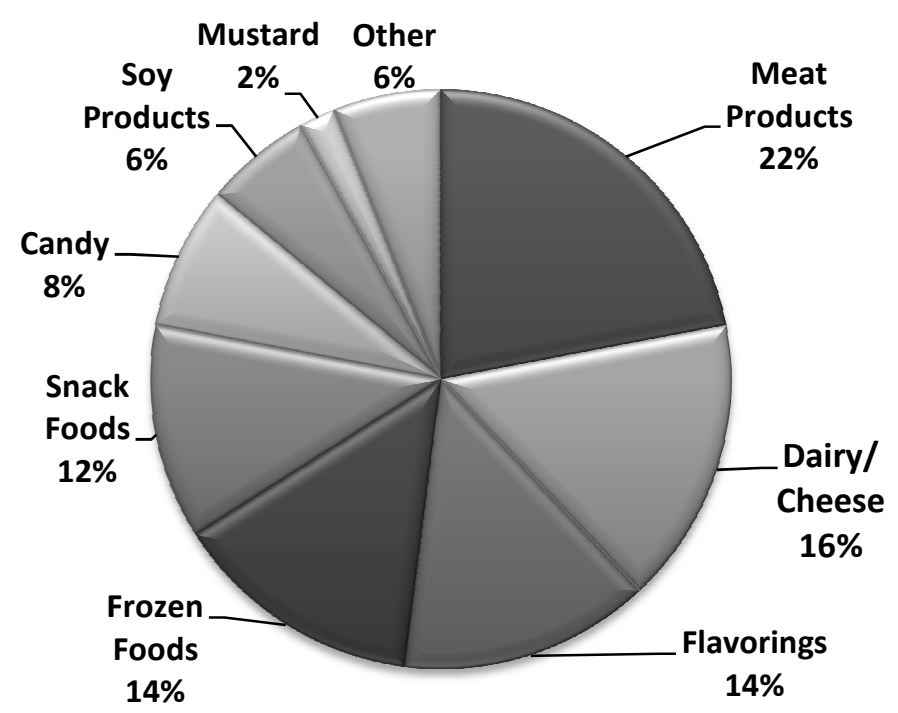

(b) Food production waste tested

Figure 1.6: Sources of wastes identified for co-digestion

\subsubsection{Identify most promising co-digestates}

From preliminary screening, 46 wastes (see Table 1.6) were chosen for characterization based upon the significant volume produced, high COD concentration, and/or proximity to the digester. 
Table 1.6: Waste characteristics and facility descriptions for potential co-digestates

\begin{tabular}{|c|c|c|c|c|}
\hline Waste & $\begin{array}{c}\text { COD }(\mathrm{mg} / \mathrm{L} \\
\text { or other as } \\
\text { marked) }\end{array}$ & $\begin{array}{l}\text { TS } \\
(\%)\end{array}$ & Description & $\begin{array}{l}\text { Distance to } \\
\text { digester, } \\
\text { km }\end{array}$ \\
\hline Cooking solids & $1,056,000^{*}$ & 46.8 & \multirow{2}{*}{ Meat Production } & \multirow{2}{*}{10} \\
\hline Wood chip/Charcoal & $660,000 *$ & 39.6 & & \\
\hline Flavorings yeast & 216,000 & 15.7 & \multirow{3}{*}{$\begin{array}{l}\text { Food flavorings } \\
\text { production }\end{array}$} & \multirow{3}{*}{12} \\
\hline Yeast centrate & 35,000 & 0.6 & & \\
\hline Sprout & $127,000 *$ & 14.3 & & \\
\hline Oil and hydraulic fluids & 77,000 & 2.6 & Metal recycling facility & 20 \\
\hline Compost & $174,000 *$ & 56.8 & \multirow{2}{*}{$\begin{array}{l}\text { Garden waste (Plant } \\
\text { wastes, grass, clippings } \\
\text { and cocoa husks) }\end{array}$} & \multirow{2}{*}{21} \\
\hline Cocoa husks & $350,000 *$ & 64.1 & & \\
\hline Alage (Botrycoccus braunii) & $1,749,000^{*}$ & 98.7 & \multirow{2}{*}{ Liquid bio-fuel from algae } & \multirow{2}{*}{24} \\
\hline Alage (Nannochloropsis) & $1,413000^{*}$ & 96.8 & & \\
\hline Lettuce & $50,000 *$ & 7.0 & \multirow{4}{*}{ Vegetable food production } & \multirow{4}{*}{24} \\
\hline Pine apple & $94,000 *$ & 4.1 & & \\
\hline Potatoes waste & $126,000^{*}$ & 14.7 & & \\
\hline Cabbage waste & $50,000 *$ & 4.8 & & \\
\hline Heads from rum distillation & $1,444,000$ & 0.0 & Rum distillation & \multirow{3}{*}{25} \\
\hline Molasses wash & 126,000 & 9.3 & Rum fermentation & \\
\hline $\begin{array}{l}\text { Corn/Rye/Wheat/Barley in } \\
\text { liquid }\end{array}$ & 172,000 & 11.9 & Distillation & \\
\hline Float & $133,000 *$ & 12.5 & $\begin{array}{l}\text { Dissolved air flotation } \\
\text { float from meat } \\
\text { production }\end{array}$ & \multirow{3}{*}{26} \\
\hline Paunch & $105,000 *$ & 10.6 & \multirow{2}{*}{ Meat production } & \\
\hline Dried manure & $449,000 *$ & 86.4 & & \\
\hline Pre-filter slurry & 39,000 & 11.9 & Shave gel production & 26 \\
\hline Trube & 203,000 & 9.9 & \multirow{3}{*}{ Beer fermentation } & \multirow{3}{*}{29} \\
\hline Brewery yeast & 313,000 & 16.2 & & \\
\hline Brewery grain & 107,000 & 20.1 & & \\
\hline
\end{tabular}

* These values are in units of $\mathrm{mg} / \mathrm{kg}$ (wet) 
Table 1.6: Waste characteristics and facility descriptions for potential co-digestates (continued)

\begin{tabular}{|c|c|c|c|c|}
\hline Waste & $\begin{array}{c}\text { COD }(\mathrm{mg} / \mathrm{L} \\
\text { or other as } \\
\text { marked) }\end{array}$ & TS & Description $^{1}$ & $\begin{array}{c}\begin{array}{c}\text { Distance to } \\
\text { digester, } \\
\text { km }\end{array} \\
\end{array}$ \\
\hline Soap & 47,000 & 2.0 & Soap production & 29 \\
\hline Corrigated cardboard & $1,184,000^{*}$ & 92.6 & $\mathrm{~N} / \mathrm{K}$ & 30 \\
\hline Boiler cleaning waste & 33,000 & 5.7 & $\begin{array}{c}\text { Coal-fired boiler heat } \\
\text { exchanger cleaning } \\
\text { solution }\end{array}$ & 48 \\
\hline Metal cutting waste & 75,000 & 2.3 & Machine shop & 48 \\
\hline Mustard waste & $59,000^{*}$ & 8.5 & Mustard production & 53 \\
\hline Sorghum & 89,000 & 5.6 & Winery production & 56 \\
\hline Packaging waste & $972,000^{*}$ & 76.8 & $\begin{array}{l}\text { Waste candy from } \\
\text { packaging operation }\end{array}$ & 71 \\
\hline White waste & $1,089,000^{*}$ & 90.1 & $\begin{array}{l}\text { Floor sweepings from } \\
\text { candy production }\end{array}$ & 71 \\
\hline Acid whey & 148,000 & 12.7 & Soft cheese production & 79 \\
\hline Confectionary & 23,000 & 1.9 & Candy production & 89 \\
\hline Waste rice & $287,000 *$ & 22.7 & \multirow{2}{*}{ Frozen food production } & \multirow{2}{*}{98} \\
\hline Waste noodle & $502,000 *$ & 35.3 & & \\
\hline Cheese waste & $438,000 *$ & 72.1 & Cheese production & 106 \\
\hline Wet distillers grain & $206,000 *$ & 31.1 & \multirow{4}{*}{ Corn ethanol production } & \multirow{4}{*}{110} \\
\hline Syrup & 399,000 & 30.4 & & \\
\hline Whole stillage & 155,000 & 14.5 & & \\
\hline Thin stillage & 137,000 & 9.1 & & \\
\hline Can crushing waste & 76,000 & 6.1 & Soft drink production & 120 \\
\hline Cookie waste & 13,000 & 0.6 & Industrial bakery & 153 \\
\hline Dewatered paper mill sludge & $311,000 *$ & 35.6 & Paper/tissue production & 156 \\
\hline Corn Stover & $1,662,000 *$ & 90.3 & Corn Production & 160 \\
\hline FT reactor condensate & 104,000 & 0.0 & Liquid bio-fuel from wood & 1535 \\
\hline
\end{tabular}

* These values are in units of $\mathrm{mg} / \mathrm{kg}$ (wet)

${ }^{1} \mathrm{~N} / \mathrm{K}$ : Not known 


\subsubsection{Constituent analyses}

Summary of waste constituent analyses for 46 wastes which were chosen from the market study are presented in Table 1.7. These constituent analyses included pH, TS, VS, TSS, VSS, COD, total phosphorous, $\mathrm{NH}_{3}-\mathrm{N}, \mathrm{TKN}$, FOG, alkalinity and selected metals in each waste. The selected metals analyses included heavy metals: cadmium, chromium, lead, arsenic, mercury, trace metals: copper, selenium, nickel, zinc, molybdenum and light metals: potassium and silver. Based on the metals analysis, trube, brewing yeast, acid whey and soap waste contained high potassium concentrations (540, 2300, 3300 and $900 \mathrm{mg} / \mathrm{L}$, respectively). Boiler cleaning waste contained significant amounts of copper (68 mg/L) and chromium $(6.9 \mathrm{mg} / \mathrm{L})$. The FOG concentrations of waste are presented in Table 1.7. High FOG was observed in float waste $(59400 \mathrm{mg} / \mathrm{kg}$ of wet sample) and in syrup (51640 mg/L). 
Table 1.7: Summary of waste characteristics

\begin{tabular}{|c|c|c|c|c|c|c|c|}
\hline & 1 & 2 & 3 & 4 & 5 & 6 & 7 \\
\hline Parameters & Trube & Brewing yeast & Grain & Cookie & Soap & Packaging & White waste \\
\hline $\mathrm{pH}$ & 4.02 & 4.88 & 3.9 & 4.79 & 12.26 & - & - \\
\hline TS (\%) & 9.9 & 16.2 & 21.4 & 0.6 & 2 & 89.1 & 91.1 \\
\hline VS (\%) & 9.5 & 14.3 & 20.1 & 0.5 & 1.2 & 76.8 & 90.1 \\
\hline TSS (mg/L) & 33933 & 138200 & - & 3330 & 59 & - & - \\
\hline VSS (mg/L) & 33133 & 129333 & - & 2997 & 40 & - & - \\
\hline $\operatorname{COD}(\mathrm{mg} / \mathrm{L})$ & 203,294 & 313,380 & 107377* & 12,543 & 47,299 & 972 083* & 1089391* \\
\hline Total Phosphorus (mg/L) & 248 & 1,509 & $3973 *$ & 19 & 87 & $86.3^{*}$ & $400 *$ \\
\hline NH3-N (mg/L) & 50 & 218 & $66 *$ & 0 & 137 & $0.7^{*}$ & $0.06^{*}$ \\
\hline TKN (mg/L) & 2,828 & 24,724 & 41698* & 51 & 241 & $45.7^{*}$ & $3.67^{*}$ \\
\hline FOG (mg/L) & 4,580 & 280 & $\mathrm{~N} / \mathrm{A}$ & 3,309 & 4,837 & $18^{*}$ & 21 \\
\hline Alkalinity (mg/L as CaCO3) & 0 & 35.7 & 0 & 34.8 & 4994 & - & - \\
\hline BMP (mlCH4/gCOD or $\underline{\mathrm{mlCH} 4 / \mathrm{gVS}}$ ) & $373 \pm 15$ & $373 \pm 6$ & $\underline{367 \pm 8}$ & $418 \pm 19$ & $<20$ & $301 \pm 12$ & $306 \pm 9$ \\
\hline ATA & $\mathrm{I} \mathrm{C}_{50}=1.8 \%$ & IC50=4.7\% & $\mathrm{IC} 50>10 \%$ & IC50>50\% & $\mathrm{IC} 50=2 \%$ & $\mathrm{IC} 50>1 \%$ & IC50>1\% \\
\hline$d_{10 \%}$ Passing $(\mathrm{mm})$ & $<0.053$ & $<0.053$ & $<0.053$ & $<0.053$ & $<0.053$ & $>4.75$ & $<0.71$ \\
\hline $\mathbf{d}_{50 \%}$ Passing (mm) & $<0.053$ & $<0.053$ & 1.17 & 0.2 & $<0.053$ & $>4.75$ & $>4.75$ \\
\hline $\mathbf{d}_{90 \%}$ Passing $(\mathrm{mm})$ & 0.12 & $<0.053$ & $>2.0$ & 0.53 & $<0.053$ & $>4.75$ & $>4.75$ \\
\hline Cadmium (ug/L) & 3.2 & 12 & $<0.40^{*}$ & 4.4 & 1.7 & $0.01^{*}$ & $0.017^{*}$ \\
\hline Chromium (ug/L) & 13 & 80 & $<0.53^{*}$ & 13 & 17 & $0.05^{*}$ & $0.068 *$ \\
\hline Copper (ug/L) & 7300 & 5000 & $20^{*}$ & 370 & 86 & $0.8^{*}$ & $0.8^{*}$ \\
\hline Lead (ug/L) & $<13$ & $<13$ & $<5.6^{*}$ & 29 & $<13$ & $0.11^{*}$ & $<0.052^{*}$ \\
\hline Nickel (ug/L) & 22 & 22 & $1.2^{*}$ & 18 & $<12$ & $<0.03^{*}$ & $<0.052^{*}$ \\
\hline Zinc (ug/L) & 2700 & 9000 & $78 *$ & 520 & 50000 & $26^{*}$ & $1.76^{*}$ \\
\hline Arsenic (ug/L) & $<2.4$ & $<2.4$ & $<3.7^{*}$ & 5.9 & $<2.4$ & $<0.34^{*}$ & $<0.48^{*}$ \\
\hline Selenium (ug/L) & 15 & $<31$ & $8.2^{*}$ & $<3.1$ & $<3.1$ & $<0.43^{*}$ & $<0.6^{*}$ \\
\hline Silver (ug/L) & $<12$ & $<12$ & $<0.36^{*}$ & $<1.2$ & $<12$ & $<0.034^{*}$ & $<0.048^{*}$ \\
\hline Molybdenum (ug/L) & 510 & 370 & 3* & $<3.3$ & $<33$ & $<0.09 *$ & $<0.132^{*}$ \\
\hline Potassium (ug/L) & 540,000 & $2,300,000$ & $0.017 \%$ DWB & 21,000 & 900,000 & $94 *$ & $216^{*}$ \\
\hline Mercury (ug/L) & $<4.9$ & $<27$ & $<0.064^{*}$ & $<4.8$ & $<49$ & $<0.001^{*}$ & $<0.006^{*}$ \\
\hline Quantity (gal/day or lb/day) & 750gpd & 10000gpd & $\mathrm{N} / \mathrm{A}$ & $600 \mathrm{gpd}$ & 10000gpd & $\mathrm{N} / \mathrm{A}$ & 40000lb/day \\
\hline
\end{tabular}

* - Unit: $\mathrm{mg} / \mathrm{Kg}$ of sample 
Table 1.7: Summary of waste characteristics (continued)

\begin{tabular}{|c|c|c|c|c|c|c|c|}
\hline & 8 & 9 & 10 & 11 & 12 & 13 & 14 \\
\hline Parameters & Confectionary & Float & Paunch & Manure & Flavorings yeast & Yeast centrate & Sprout \\
\hline $\mathrm{pH}$ & 6.1 & 5.5 & 7.29 & - & 5.4 & 4.96 & 5.75 \\
\hline TS (\%) & 1.9 & 12.53 & 13.04 & 92.86 & 15.71 & 0.59 & 15.00 \\
\hline VS (\%) & 1.8 & 11.31 & 10.56 & 86.42 & 15.09 & 0.57 & 14.33 \\
\hline TSS (mg/L) & 33232 & - & - & - & 168333 & 1127 & - \\
\hline VSS (mg/L) & 29277 & - & - & - & 330444 & 1260 & - \\
\hline $\operatorname{COD}(\mathrm{mg} / \mathrm{L})$ & 23,150 & 132816* & 104847* & 449369* & 215,599 & 35,479 & 127243* \\
\hline Total Phosphorus (mg/L) & 31 & 5179* & 8223* & 2163* & 1,123 & 67 & 4403* \\
\hline NH3-N (mg/L) & $<0.03$ & $3967^{*}$ & $920^{*}$ & $414^{*}$ & 112 & 11 & 1968* \\
\hline TKN (mg/L) & 7 & 41752* & 19522* & 2768* & 10,904 & 801 & $53522 *$ \\
\hline FOG $(\mathrm{mg} / \mathrm{L})$ & 933 & $59400 *$ & $\mathrm{~N} / \mathrm{A}$ & $\mathrm{N} / \mathrm{A}$ & 2,530 & 4,465 & $\mathrm{~N} / \mathrm{A}$ \\
\hline Alkalinity (mg/L as CaCO3) & 242.6 & - & - & - & & & - \\
\hline 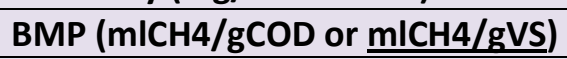 & $346 \pm 14$ & $416 \pm 19$ & $237 \pm 20$ & $51 \pm 8$ & $326 \pm 34$ & $285 \pm 6$ & $389 \pm 13$ \\
\hline ATA & $\mathrm{IC} 50>40 \%$ & $\mathrm{IC} 50>10 \%$ & $\mathrm{IC50>10 \%}$ & $I C 50>3 \%$ & IC50>5\% & IC50>30\% & $\mathrm{IC50>10 \%}$ \\
\hline$d_{10 \%}$ Passing $(\mathrm{mm})$ & $<0.053$ & $<0.075$ & $<0.71$ & $<0.71$ & $<0.053$ & $<0.053$ & $<0.053$ \\
\hline $\mathbf{d}_{50 \%}$ Passing (mm) & $<0.053$ & $<0.075$ & 1.1 & 2.26 & $<0.053$ & $<0.053$ & $>0.25$ \\
\hline $\mathbf{d}_{90 \%}$ Passing $(\mathrm{mm})$ & $<0.053$ & 0.52 & $>4.76$ & $>4.76$ & $<0.053$ & $<0.053$ & $>0.25$ \\
\hline Cadmium (ug/L) & 7 & $<0.49 *$ & $<0.39 *$ & $<0.28^{*}$ & $<0.17^{*}$ & $<2.9 *$ & $<0.34^{*}$ \\
\hline Chromium (ug/L) & 59 & $11^{*}$ & $<0.52 *$ & $2.9^{*}$ & $\left\langle 0.25^{*}\right\rangle$ & $<3.9 *$ & $<0.45^{*}$ \\
\hline Copper (ug/L) & 600 & $31 *$ & $22^{*}$ & $11^{*}$ & $11^{*}$ & $56^{*}$ & $9.7^{*}$ \\
\hline Lead (ug/L) & $<13$ & $<6.9 *$ & $<5.6^{*}$ & $<4.0^{*}$ & $<2.4^{*}$ & $<41^{*}$ & $<4.8^{*}$ \\
\hline Nickel (ug/L) & 41 & $6.6^{*}$ & $1.9 *$ & $2.1^{*}$ & $2.3^{*}$ & $<6.2^{*}$ & $<2.5^{*}>$ \\
\hline Zinc (ug/L) & 1700 & $200 *$ & $85^{*}$ & $<2.5^{*}$ & $560 *$ & $<6.4 *>$ & $69 *$ \\
\hline Arsenic (ug/L) & $<12$ & $<4.2^{*}$ & $<3.8^{*}$ & $<2.5^{*}$ & $<1.7^{*}$ & $<27^{*}$ & $<3.2^{*}$ \\
\hline Selenium (ug/L) & $<15$ & $<5.2^{*}$ & $<4.8^{*}$ & $<3.1^{*}$ & $<2.1^{*}$ & $<34^{*}$ & $<0.4^{*}$ \\
\hline Silver (ug/L) & $<12$ & $<0.44^{*}$ & $<0.36^{*}$ & $<0.025^{*}$ & $<0.15^{*}$ & $<2.6^{*}$ & $<0.3^{*}$ \\
\hline Molybdenum (ug/L) & $<33$ & $1.5^{*}$ & $1.2^{*}$ & $0.77^{*}$ & $<3.0^{*}$ & $\left\langle 8.3^{*}\right\rangle$ & $<1.1 *>$ \\
\hline Potassium (ug/L) & 14000 & $0.079 \% \mathrm{DWB}$ & 0.39\%DWB & $0.43 \% \mathrm{DWB}$ & $0.21 \% \mathrm{DWB}$ & $0.74 \% \mathrm{DWB}$ & $0.93 \% \mathrm{DWB}$ \\
\hline Mercury (ug/L) & $<0.05$ & $<0.095^{*}$ & $<0.17^{*}$ & $<0.083^{*}$ & $<0.067^{*}$ & $<0.54^{*}$ & $<0.08^{*}$ \\
\hline Quantity (gal/day or lb/day) & $275 \mathrm{gpd}$ & 10000gpd & $50000 \mathrm{gpd}$ & $\mathrm{N} / \mathrm{A}$ & $192000 \mathrm{lb} / \mathrm{wk}$ & $108000 \mathrm{lb} / \mathrm{wk}$ & 3000 gpd \\
\hline
\end{tabular}

* - Unit: $\mathrm{mg} / \mathrm{Kg}$ of sample 
Table 1.7: Summary of waste characteristics (continued)

\begin{tabular}{|c|c|c|c|c|c|c|c|}
\hline & 15 & 16 & 17 & 18 & 19 & 20 & 21 \\
\hline Parameters & Wet distill. grain & Syrup & Whole sitillage & Thin stillage & Waste rice & Waste noodle & Acid whey \\
\hline $\mathrm{pH}$ & 3.65 & 3.52 & 3.51 & 3.61 & 3.30 & 4.38 & 4.51 \\
\hline TS (\%) & 32.94 & 30.44 & 14.45 & 9.12 & 22.98 & 36.21 & 12.70 \\
\hline VS (\%) & 31.14 & 27.44 & 13.49 & 8.27 & 22.69 & 35.29 & 10.75 \\
\hline TSS (mg/L) & - & - & - & - & - & - & 221 \\
\hline VSS (mg/L) & - & - & - & - & - & - & 189 \\
\hline $\operatorname{COD}(\mathrm{mg} / \mathrm{L})$ & 206243* & 398,718 & 154,778 & 137,241 & $286867^{*}$ & 502416* & 147,990 \\
\hline Total Phosphorus (mg/L) & 15179* & 9,996 & 3,067 & 1,395 & $124.3^{*}$ & $382.5^{*}$ & 1,595 \\
\hline NH3-N (mg/L) & $400^{*}$ & 246 & 34 & 42 & 158.3* & $131.5^{*}$ & 272 \\
\hline TKN (mg/L) & 24775* & 2,722 & 9,447 & 3,086 & 2490* & $4332^{*}$ & 848 \\
\hline FOG (mg/L) & $\mathrm{N} / \mathrm{A}$ & 51,640 & N/A & 31,370 & $\mathrm{~N} / \mathrm{A}$ & $\mathrm{N} / \mathrm{A}$ & 748 \\
\hline Alkalinity (mg/L as CaCO3) & - & - & - & - & - & - & 0 \\
\hline 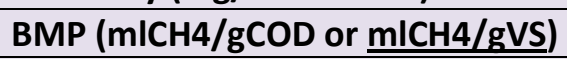 & $473 \pm 15$ & $396 \pm 22$ & $399 \pm 7$ & $351 \pm 14$ & $414 \pm 21$ & $453 \pm 10$ & $295 \pm 3$ \\
\hline ATA & IC50>6\% & IC50>4\% & $\mathrm{IC} 50>10 \%$ & IC50>12\% & $\mathrm{IC} 50>6 \%$ & IC50>3\% & IC50>8\% \\
\hline$d_{10 \%}$ Passing $(\mathrm{mm})$ & $<0.075$ & $<0.053$ & $<0.075$ & $<0.075$ & $>4.75$ & $>4.75$ & $<0.053$ \\
\hline $\mathbf{d}_{50 \%}$ Passing (mm) & 0.47 & $<0.053$ & 0.39 & $<0.075$ & $>4.75$ & $>4.75$ & $<0.053$ \\
\hline $\mathbf{d}_{90 \%}$ Passing $(\mathrm{mm})$ & 1.46 & $<0.053$ & $>0.71$ & $<0.075$ & $>4.75$ & $>4.75$ & $<0.053$ \\
\hline Cadmium (ug/L) & $<0.16^{*}$ & $<0.18^{*}$ & $<0.17^{*}$ & $<0.28 *$ & $<0.25^{*}$ & $<0.16^{*}$ & $<1.8>$ \\
\hline Chromium (ug/L) & $\langle 0.29 *\rangle$ & $\left\langle 0.35^{*}\right\rangle$ & $\left\langle 0.24^{*}\right\rangle$ & $<0.47>$ & $<0.33^{*}$ & $\left\langle 0.72^{*}\right\rangle$ & 53 \\
\hline Copper (ug/L) & $3.9^{*}$ & $4.2^{*}$ & $4.1^{*}$ & $4.1^{*}$ & $2.2^{*}$ & $2.8^{*}$ & $<6.7$ \\
\hline Lead (ug/L) & $<2.3^{*}$ & $<2.5^{*}$ & $<2.5^{*}$ & $<3.9 *$ & $<3.6^{*}$ & $<2.3^{*}$ & $<6.5$ \\
\hline Nickel (ug/L) & $2.0^{*}$ & $2.9^{*}$ & $3.1^{*}$ & $3.2^{*}$ & $\left\langle 1.7^{*}\right\rangle$ & $2.0^{*}$ & $<6.0$ \\
\hline Zinc (ug/L) & $44^{*}$ & $80 *$ & $51^{*}$ & $83^{*}$ & $15^{*}$ & $14^{*}$ & 3300 \\
\hline Arsenic (ug/L) & $<1.5^{*}$ & $<1.6^{*}$ & $<1.7^{*}$ & $<2.8^{*}$ & $<2.2^{*}$ & $<1.5^{*}$ & $<120$ \\
\hline Selenium (ug/L) & $<1.8^{*}$ & $<2.0^{*}$ & $<2.1^{*}$ & $<3.5^{*}$ & $<2.7^{*}$ & $<1.8^{*}$ & $<15$ \\
\hline Silver (ug/L) & $<0.14^{*}$ & $<0.16^{*}$ & $<0.16^{*}$ & $<0.25^{*}$ & $<0.23^{*}$ & $<0.15^{*}$ & $<6.0$ \\
\hline Molybdenum (ug/L) & $\langle 0.74 *\rangle$ & $\left\langle 0.43^{*}\right\rangle$ & $<0.53 *\rangle$ & $\left\langle 0.77^{*}\right\rangle$ & $<0.48^{*}$ & $<0.31 *$ & $<3.3$ \\
\hline Potassium (ug/L) & $0.98 \% \mathrm{DWB}$ & $2.1 \% \mathrm{DWB}$ & $1.2 \% \mathrm{DWB}$ & $2.1 \% \mathrm{DWB}$ & $0.029 \mathrm{WB}$ & $0.086 \% \mathrm{DWB}$ & 3300000 \\
\hline Mercury (ug/L) & $<0.09 *$ & $<0.054^{*}$ & $<0.066^{*}$ & $<0.051^{*}$ & $<0.078^{*}$ & $<0.035^{*}$ & $<0.25$ \\
\hline Quantity (gal/day or lb/day) & $\mathrm{N} / \mathrm{A}$ & $86000 \mathrm{gpd}$ & 680000gpd & 430000gpd & $\mathrm{N} / \mathrm{A}$ & $\mathrm{N} / \mathrm{A}$ & $\mathrm{N} / \mathrm{A}$ \\
\hline
\end{tabular}

* - Unit: $\mathrm{mg} / \mathrm{Kg}$ of sample 
Table 1.7: Summary of waste characteristics (continued)

\begin{tabular}{|c|c|c|c|c|c|c|c|}
\hline & 22 & 23 & 24 & 25 & 26 & 27 & 28 \\
\hline Parameters & $\begin{array}{l}\text { Boiler } \\
\text { cleaning }\end{array}$ & $\begin{array}{l}\text { Mustard } \\
\text { waste }\end{array}$ & Metal Cutting & $\begin{array}{c}\text { Oil and } \\
\text { hydraulic fluids }\end{array}$ & $\begin{array}{c}\text { Can crushing } \\
\text { waste }\end{array}$ & Sorghum & $\begin{array}{c}\text { Heads from rum } \\
\text { distillation }\end{array}$ \\
\hline $\mathrm{pH}$ & 9.32 & 3.42 & 9.40 & 5.59 & $3.30-3.35$ & 4.58 & 6.66 \\
\hline TS (\%) & 5.75 & 9.21 & 2.29 & 2.60 & 6.76 & 5.57 & 0.00 \\
\hline VS (\%) & 4.80 & 8.53 & 2.23 & 2.37 & 6.72 & 4.78 & 0.00 \\
\hline TSS (mg/L) & 873 & 64600 & 276 & 353 & 235 & 5513 & 12 \\
\hline VSS (mg/L) & 713 & 63600 & 273 & 271 & 234 & 5307 & 7 \\
\hline COD (mg/L) & 32,906 & $58,698^{*}$ & 75,351 & 76,875 & 81,749 & 89038 & 1443595 \\
\hline Total Phosphorus (mg/L) & 79 & 914 & 123 & 22 & 50 & 272 & 1.98 \\
\hline NH3-N (mg/L) & - & 43 & 133 & 395 & 3 & 17.4 & ND \\
\hline TKN (mg/L) & - & 4,259 & 1,085 & 672 & 27 & 1410 & 210 \\
\hline FOG (mg/L) & - & 5,320 & 32,150 & 7,350 & 416 & 380 & 50 \\
\hline Alkalinity (mg/L as CaCO3) & 5710 & 0 & 2720 & 1365 & 0 & 243 & 8 \\
\hline $\begin{array}{l}\text { BMP (mICH4/gCOD or } \\
\text { mICH4/gVS) }\end{array}$ & $<20$ & $580 \pm 25$ & $65 \pm 8$ & $79 \pm 4$ & $320 \pm 15$ & $260 \pm 9$ & $368 \pm 12$ \\
\hline ATA & $\mathrm{IC} 50=9.5 \%$ & IC50 = 14.4\% & IC50 = $12.5 \%$ & IC $50>15 \%$ & IC50>15\% & $>12 \%$ & $>0.8 \%$ \\
\hline d10\% Passing (mm) & $<0.053$ & $<0.149$ & $<0.053$ & $<0.053$ & $<0.053$ & $<0.053$ & $<0.053$ \\
\hline d50\% Passing (mm) & $<0.053$ & 1.27 & $<0.053$ & $<0.053$ & $<0.053$ & $<0.053$ & $<0.053$ \\
\hline d90\% Passing (mm) & $<0.053$ & $>2.0$ & $<0.053$ & $<0.053$ & $<0.053$ & $<0.053$ & $<0.053$ \\
\hline Cadmium (ug/L) & 120 & $<0.024 *>$ & $<0.021^{*}$ & $<0.71^{*}$ & $<0.44>$ & 1.7 & $<0.85$ \\
\hline Chromium (ug/L) & 6900 & $0.21^{*}$ & $<0.040 *>$ & $\left.<3.1^{*}\right\rangle$ & 44 & 23 & $<0.5$ \\
\hline Copper (ug/L) & 68000 & $0.87^{*}$ & $5.2^{*}$ & $170 *$ & 35 & 18000 & 23 \\
\hline Lead (ug/L) & $<450$ & $3.7^{*}$ & $3.7^{*}$ & $120 *$ & $<6.9>$ & 18 & $<0.5$ \\
\hline Nickel (ug/L) & 18000 & $0.34^{*}$ & $<0.13 *>$ & $22 *$ & 31 & 83 & $<3.7$ \\
\hline Zinc (ug/L) & 6600 & $5.4^{*}$ & $5.4^{*}$ & $650 *$ & 380 & 1100 & 64 \\
\hline Arsenic (ug/L) & 740 & $<0.17^{*}$ & $<0.18^{*}$ & $<7.0^{*}$ & 58 & 7.5 & $<6.5$ \\
\hline Selenium (ug/L) & $<580$ & $<0.21^{*}$ & $<0.23^{*}$ & $<8.8^{*}$ & 47 & $<12$ & $<12$ \\
\hline Silver (ug/L) & $<60$ & $<0.018^{*}$ & $<0.019 *$ & $<0.64^{*}$ & $<1.4>$ & $<1.1$ & $<1.1$ \\
\hline Molybdenum (ug/L) & - & $<0.038^{*}$ & $<0.040^{*}$ & $11^{*}$ & $<9.0>$ & 31 & $<3.8$ \\
\hline Potassium (ug/L) & - & $0.018 \% W W B$ & $0.0018 \% W W B$ & $0.19 \%$ DWB & 34 & 2600 & $<0.75$ \\
\hline Mercury (ug/L) & - & $<0.0048^{*}$ & $<0.0051$ & $<0.18^{*}$ & 0.59 & 0.31 & 0.22 \\
\hline Quantity (gal/day or lb/day) & ND & ND & ND & ND & ND & $9 \mathrm{gpd}$ & 17 gpd \\
\hline
\end{tabular}

* - Unit: $\mathrm{mg} / \mathrm{Kg}$ of sample 
Table 1.7: Summary of waste characteristics (continued)

\begin{tabular}{|c|c|c|c|c|c|c|}
\hline & 29 & 30 & 31 & 32 & 33 & 34 \\
\hline Parameters & $\begin{array}{c}\text { Molasses } \\
\text { wash }\end{array}$ & Lettuce & Pine apple & $\begin{array}{l}\text { Pre-filter } \\
\text { slurry }\end{array}$ & $\begin{array}{c}\text { Corn/Rye/Wheat/Barley in } \\
\text { liquid }\end{array}$ & $\begin{array}{l}\text { Corrigated } \\
\text { Cardboard }\end{array}$ \\
\hline $\mathrm{pH}$ & 4.2 & 3.75 & 3.97 & 6.25 & 3.96 & - \\
\hline TS (\%) & 9.33 & 6.97 & 4.07 & 1.67 & 11.93 & 92.57 \\
\hline VS (\%) & 6.47 & 6.52 & 3.66 & 1.54 & 11.65 & 89.83 \\
\hline TSS (mg/L) & 6733 & - & - & - & - & - \\
\hline VSS (mg/L) & 5747 & - & - & - & - & - \\
\hline COD (mg/L) & 125661 & 49554* & $94061^{*}$ & 38555 & 171856 & 1184432* \\
\hline Total Phosphorus (mg/L) & 329 & $215^{*}$ & $50 *$ & 7.2 & 312 & $179 *$ \\
\hline NH3-N (mg/L) & 37.5 & $93^{*}$ & $43^{*}$ & 202 & 19.9 & $34 *$ \\
\hline TKN (mg/L) & 1720 & $1230 *$ & $820^{*}$ & 370 & 2540 & $832 *$ \\
\hline FOG $(\mathrm{mg} / \mathrm{L})$ & 3300 & $325 *$ & $5822^{*}$ & 710 & ND & 8* \\
\hline Alkalinity (mg/L as $\mathrm{CaCO}$ ) & 0 & 0 & 0 & - & - & - \\
\hline $\begin{array}{l}\text { BMP (mlCH4/gCOD or } \\
\text { mlCH4/gVS) }\end{array}$ & $251 \pm 14$ & $328 \pm 22$ & $516 \pm 21$ & $352 \pm 23$ & $326 \pm 11$ & $347 \pm 20$ \\
\hline ATA & $>8 \%$ & $25 \%$ & $>15 \%$ & $>30 \%$ & $>8 \%$ & $1.1 \%$ \\
\hline d10\% Passing (mm) & $<0.053$ & $\mathrm{~N} / \mathrm{A}$ & $\mathrm{N} / \mathrm{A}$ & - & 0 & $\mathrm{~N} / \mathrm{A}$ \\
\hline d50\% Passing (mm) & $<0.053$ & $\mathrm{~N} / \mathrm{A}$ & $\mathrm{N} / \mathrm{A}$ & - & - & $\mathrm{N} / \mathrm{A}$ \\
\hline d90\% Passing (mm) & $<0.053$ & $\mathrm{~N} / \mathrm{A}$ & $\mathrm{N} / \mathrm{A}$ & - & - & $\mathrm{N} / \mathrm{A}$ \\
\hline Cadmium (ug/L) & 5.8 & 0.09 & 0.38 & $<1.3$ & 62.8 & 0.13 \\
\hline Chromium (ug/L) & 240 & 0.47 & 1.33 & $<30>$ & 298 & 3.59 \\
\hline Copper (ug/L) & 17000 & 8.42 & 15.29 & 84 & 8212 & 59.5 \\
\hline Lead (ug/L) & 520 & 1.57 & 1.01 & $<13$ & 1340 & 7.6 \\
\hline Nickel (ug/L) & 370 & 2.3 & 9.5 & $<18$ & 34560 & 28 \\
\hline Zinc (ug/L) & 2000 & 6.4 & 9.8 & 160 & 9640 & 71.9 \\
\hline Arsenic (ug/L) & $<7.5$ & 0.04 & 0.05 & 7.3 & 12.8 & ND \\
\hline Selenium (ug/L) & $<12$ & 0.06 & 0 & $<12$ & 111 & 5.8 \\
\hline Silver (ug/L) & 13 & 13.9 & 17.4 & $<14$ & 13820 & 161 \\
\hline Molybdenum (ug/L) & 350 & 0.09 & 0.07 & $<10$ & 225 & 2.97 \\
\hline Potassium (ug/L) & 8900 & 1340 & 1600 & 220 & 739000 & 566 \\
\hline Mercury (ug/L) & $<0.25$ & 0.25 & 0.3 & ND & 202 & 1.65 \\
\hline Quantity (gal/day or Ib/day) & 17 gpd & $\begin{array}{l}100000 \\
\mathrm{lbs} / \mathrm{wk}\end{array}$ & $\begin{array}{l}100000 \\
\mathrm{lbs} / \mathrm{wk}\end{array}$ & 10000 gpd & $17 \mathrm{gpd}$ & 20 yd3 /week \\
\hline
\end{tabular}

* - Unit: $\mathrm{mg} / \mathrm{Kg}$ of sample 
Table 1.7: Summary of waste characteristics (continued)

\begin{tabular}{|c|c|c|c|c|c|c|c|}
\hline & 35 & 36 & 37 & 38 & 39 & 40 & 41 \\
\hline Parameters & $\begin{array}{l}\text { FT reactor } \\
\text { condensate }\end{array}$ & $\begin{array}{l}\text { Cheese } \\
\text { waste }\end{array}$ & $\begin{array}{l}\text { Cooking } \\
\text { solids }\end{array}$ & $\begin{array}{c}\text { Wood } \\
\text { chip/Charcoal }\end{array}$ & $\begin{array}{c}\text { Dewatered paper } \\
\text { mill sludge }\end{array}$ & Compost & $\begin{array}{l}\text { Cocoa } \\
\text { husks }\end{array}$ \\
\hline $\mathrm{pH}$ & 3.25 & - & - & - & - & - & - \\
\hline TS (\%) & 0.01 & 72.09 & 46.76 & 39.56 & 35.55 & 56.76 & 64.10 \\
\hline VS (\%) & 0.01 & 68.01 & 44.63 & 37.85 & 16.96 & 16.19 & 27.21 \\
\hline TSS (mg/L) & 12 & - & - & - & - & - & - \\
\hline VSS (mg/L) & 8 & - & - & - & - & - & - \\
\hline COD (mg/L) & 103646 & $438005^{*}$ & 1056489* & 659947* & $311115^{*}$ & $174092^{*}$ & 350149* \\
\hline Total Phosphorus (mg/L) & 0.8 & $4615^{*}$ & 1189 & 561 & 78.8 & 474 & 1735 \\
\hline NH3-N (mg/L) & ND & 6313* & 343 & 10.9 & 0.4 & 140 & 4.9 \\
\hline TKN (mg/L) & ND & $35640 *$ & 17094 & 181 & 0.5 & 4423 & 1022 \\
\hline FOG (mg/L) & ND & 272000 & 650 & 210 & ND & 450 & 595 \\
\hline Alkalinity (mg/L as $\mathrm{CaCO} 3)$ & - & N/A & N/A & $\mathrm{N} / \mathrm{A}$ & $\mathrm{N} / \mathrm{A}$ & $\mathrm{N} / \mathrm{A}$ & N/A \\
\hline $\begin{array}{l}\text { BMP (mlCH4/gCOD or } \\
\text { mICH4/gVS) }\end{array}$ & $365 \pm 14$ & $241 \pm 28$ & $366 \pm 6$ & $60 \pm 11$ & $254 \pm 32$ & $39 \pm 6$ & $49 \pm 11$ \\
\hline ATA & $>12 \%$ & $>3 \%$ & $>1 \%$ & $>1.6 \%$ & $>3 \%$ & $>6 \%$ & $>3 \%$ \\
\hline d10\% Passing (mm) & $<0.053$ & N/A & N/A & $\mathrm{N} / \mathrm{A}$ & $\mathrm{N} / \mathrm{A}$ & $\mathrm{N} / \mathrm{A}$ & N/A \\
\hline d50\% Passing (mm) & $<0.053$ & N/A & $\mathrm{N} / \mathrm{A}$ & $\mathrm{N} / \mathrm{A}$ & $\mathrm{N} / \mathrm{A}$ & $\mathrm{N} / \mathrm{A}$ & N/A \\
\hline d90\% Passing (mm) & $<0.053$ & N/A & N/A & $\mathrm{N} / \mathrm{A}$ & $\mathrm{N} / \mathrm{A}$ & $\mathrm{N} / \mathrm{A}$ & N/A \\
\hline Cadmium (ug/L) & 0.16 & ND & 0.13 & 0.05 & 0.46 & 0.83 & 0.02 \\
\hline Chromium (ug/L) & 7.39 & 4.99 & 4.36 & 2.47 & 13.79 & 54.7 & 1.28 \\
\hline Copper (ug/L) & 198 & 9.15 & 76.9 & 15.8 & 91 & 100 & 26.6 \\
\hline Lead (ug/L) & 15.2 & 3 & 5.8 & 1.8 & 25.8 & 25.9 & 0.17 \\
\hline Nickel (ug/L) & 14.2 & 2.45 & 9.93 & 1.52 & 11.7 & 11.9 & 0.53 \\
\hline Zinc (ug/L) & 113 & 63.2 & 174 & 78.7 & 255 & 85.3 & 4.54 \\
\hline Arsenic (ug/L) & ND & ND & ND & ND & ND & 1.45 & ND \\
\hline Selenium (ug/L) & 0 & 0.34 & ND & 0.22 & 3 & 2.1 & 0.03 \\
\hline Silver (ug/L) & 244 & 44.6 & 46.6 & 19.7 & 99.8 & 36 & 1.19 \\
\hline Molybdenum (ug/L) & 27 & 0.19 & 0.26 & 0.09 & 0.94 & 0.41 & ND \\
\hline Potassium (ug/L) & 491 & 764 & 114 & 1570 & 301 & 1900 & 57.6 \\
\hline Mercury (ug/L) & 1.99 & 0.33 & 0.2 & 0.02 & 0.11 & ND & ND \\
\hline $\begin{array}{l}\text { Quantity (gal/day or } \\
\text { lb/day) }\end{array}$ & $570 \mathrm{gpd}$ & $\begin{array}{c}10-50 \\
\text { lbs/days }\end{array}$ & $2150 \mathrm{lbs} / \mathrm{day}$ & $270 \mathrm{lbs} / \mathrm{day}$ & $400,000 \mathrm{lbs} / \mathrm{day}$ & $\begin{array}{c}10 \\
\mathrm{yd} 3 / \text { month }\end{array}$ & ND \\
\hline
\end{tabular}

* - Unit: $\mathrm{mg} / \mathrm{Kg}$ of sample 
Table 1.7: Summary of waste characteristics (continued)

\begin{tabular}{|c|c|c|c|c|c|}
\hline & 42 & 43 & 44 & 45 & 46 \\
\hline Parameters & Potatoes waste & Cabbage waste & Corn Stover & Alage (Botrycoccus braunii) & Alage (Nannochloropsis) \\
\hline $\mathrm{pH}$ & - & - & - & - & - \\
\hline TS (\%) & 14.74 & 4.76 & 90.30 & 98.67 & 96.81 \\
\hline VS (\%) & 13.89 & 4.34 & 80.76 & 91.52 & 87.71 \\
\hline TSS (mg/L) & - & - & - & - & - \\
\hline VSS (mg/L) & - & - & - & - & - \\
\hline COD (mg/L) & 125952* & 49957* & $1662265^{*}$ & $1749000^{*}$ & 1413000* \\
\hline Total Phosphorus (mg/L) & 9.2 & 145 & 538000 & - & - \\
\hline NH3-N (mg/L) & 425 & 90.3 & 45400 & - & - \\
\hline TKN (mg/L) & 2483 & 1153 & 602600 & - & - \\
\hline FOG $(\mathrm{mg} / \mathrm{L})$ & 220 & 155 & 110 & - & - \\
\hline Alkalinity (mg/L as CaCO3) & $\mathrm{N} / \mathrm{A}$ & $\mathrm{N} / \mathrm{A}$ & $\mathrm{N} / \mathrm{A}$ & - & - \\
\hline BMP (mlCH4/gCOD or mlCH4/gVS) & $282 \pm 13$ & $412 \pm 4$ & $396 \pm 2$ & $500 \pm 27$ & $394 \pm 10$ \\
\hline ATA & $>10 \%$ & $>25 \%$ & $>0.8 \%$ & $>0.8 \%$ & $>0.8 \%$ \\
\hline d10\% Passing $(\mathrm{mm})$ & $\mathrm{N} / \mathrm{A}$ & $\mathrm{N} / \mathrm{A}$ & $\mathrm{N} / \mathrm{A}$ & - & - \\
\hline d50\% Passing (mm) & $\mathrm{N} / \mathrm{A}$ & $\mathrm{N} / \mathrm{A}$ & $\mathrm{N} / \mathrm{A}$ & - & - \\
\hline d90\% Passing (mm) & $\mathrm{N} / \mathrm{A}$ & $\mathrm{N} / \mathrm{A}$ & $\mathrm{N} / \mathrm{A}$ & - & - \\
\hline Cadmium (ug/L) & ND & ND & 0.9 & - & - \\
\hline Chromium (ug/L) & ND & ND & 19.2 & - & - \\
\hline Copper (ug/L) & 8.9 & 5.1 & 146 & - & - \\
\hline Lead (ug/L) & ND & ND & 24 & - & - \\
\hline Nickel (ug/L) & 1.87 & ND & 15.7 & - & - \\
\hline Zinc (ug/L) & 9.91 & 4.71 & 244 & - & - \\
\hline Arsenic (ug/L) & ND & ND & ND & - & - \\
\hline Selenium (ug/L) & ND & ND & 0.72 & - & - \\
\hline Silver (ug/L) & 7.63 & 6.11 & 147 & - & - \\
\hline Molybdenum (ug/L) & ND & ND & 0.44 & - & - \\
\hline Potassium (ug/L) & 4060 & 1730 & 17200 & - & - \\
\hline Mercury (ug/L) & ND & ND & 0.98 & - & - \\
\hline Quantity (gal/day or lb/day) & ND & ND & ND & 300 yd3 /Summer & $300 \mathrm{yd} 3 /$ month \\
\hline
\end{tabular}

* - Unit: $\mathrm{mg} / \mathrm{Kg}$ of sample 


\subsubsection{Biochemical methane potential (BMP) testing}

The BMP results for the 46 wastes are presented in Figure $1.7 \mathrm{a}$ and $\mathrm{b}$ with units of $\mathrm{mL} \mathrm{CH}_{4} / \mathrm{g} \mathrm{COD}$ and $\mathrm{mL} \mathrm{CH}_{4} / \mathrm{gVS}$. $\mathrm{CH}_{4}$ produced from all the co-digestates tested, with average BMP values (for 3 replicates) ranging from 20 to $418 \mathrm{~mL} \mathrm{CH}_{4} / \mathrm{g} \mathrm{COD}$ and 39 to $580 \mathrm{~mL} \mathrm{CH}_{4} / \mathrm{gVS}$. The BMP values of cookie and float wastes were slightly more than theoretical BMP value of $400 \mathrm{~mL} \mathrm{CH}_{4} / \mathrm{g} \mathrm{COD}$ at $35^{\circ} \mathrm{C}$. This may be due to experimental error or that the $\mathrm{CH}_{4}$ produced in the seed sludge in the blank was less than that in the assay. High BMP values ( $>370 \mathrm{~mL} \mathrm{CH}_{4} / \mathrm{gCOD}$ ) were observed for seven of the wastes: (1) cookie waste, (2) float, (3) whole stillage, (4) syrup, (5) trube (6) brewery yeast, and (7) mustard waste (see Figure 1.7 and 1.8). Low BMP values $(<100 \mathrm{~mL}$ $\mathrm{CH}_{4} / \mathrm{gCOD}$ ) were observed for oil and hydraulic fluids, metal cutting, soap, boiler cleaning, wood chip/charcoal, dried manure, cocoa husks and compost wastes (Figure $1.7 \mathrm{a}$ and $\mathrm{b}$ ). The average BMP result of glucose standards was $322 \pm 23 \mathrm{~mL} \mathrm{CH}_{4} / \mathrm{gCOD}$ (a total of 21 glucose standard assays were run). 


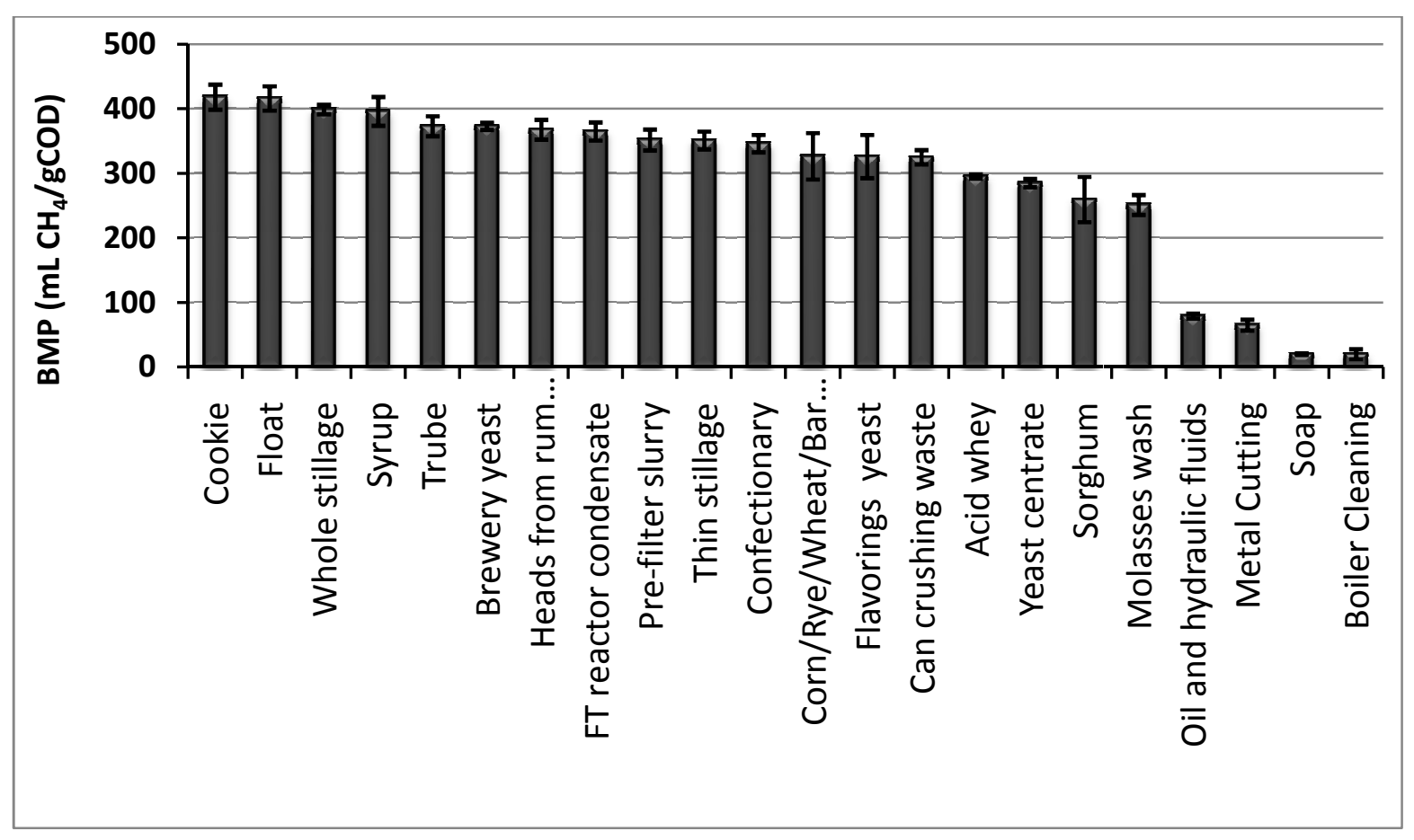

Figure 1.7(a): Biochemical methane potential (BMP) results for 22 promising co-digestates Error bars represent standard deviation of triplicate measurements. The $\mathrm{CH}_{4}$ volume is reported at $35^{\circ} \mathrm{C}, 1$ atm. Some error bars are too small to be visible.

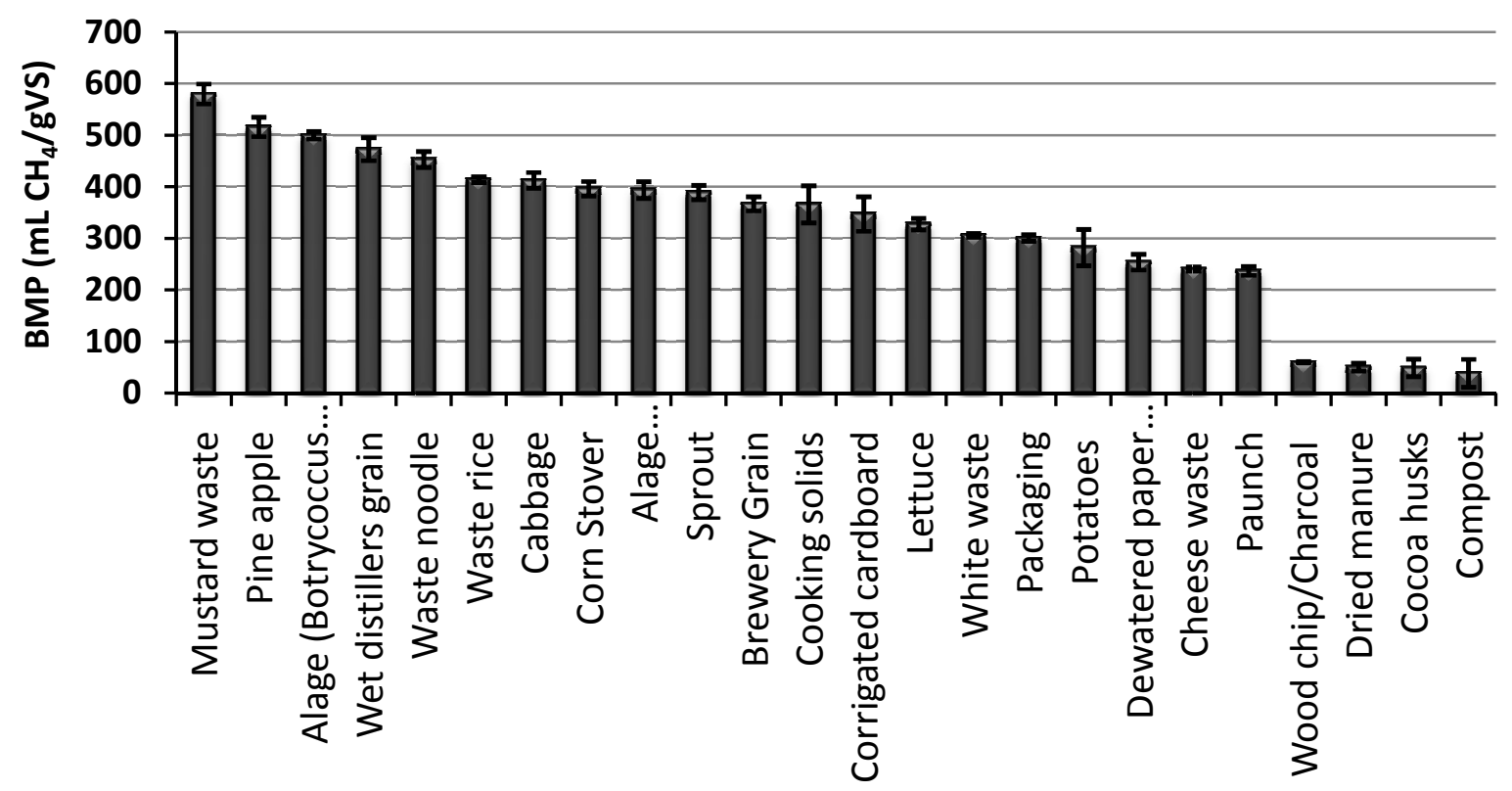

Figure 1.8(b): Biochemical methane potential (BMP) results for 24 promising co-digestates Error bars represent standard deviation of triplicate measurements. The $\mathrm{CH}_{4}$ volume is reported at $35^{\circ} \mathrm{C}, 1$ atm. Some error bars are too small to be visible. 


\subsubsection{Anaerobic toxicity assay (ATA) testing}

The ATA results for various wastes include synergistic, antagonistic, neutral and mixed outcomes based on a comparison of maximum $\mathrm{CH}_{4}$ production rates when calcium acetate was the main co-digestate in ATA testing (see Figures 1.9 through 1.12). ATA results of each outcome are shown in figures grouped by the range of doses to help present results more legibly. Whole stillage, thin stillage, can crushing waste, confectionary, yeast centrate, sorghum, potatoes waste, sprout, wet distillers grain, cheese waste, waste noodle, waste rice, syrup, molasses wash, packaging waste and white waste resulted synergistic outcomes (see Figure 1.9 (a), (b) and (c)). The maximum rate of $\mathrm{CH}_{4}$ production increased more than $50 \%$ for whole stillage, packaging, white wastes and more than $30 \%$ for yeast centrate, syrup wastes, wet distillers grain and waste noodle. Sorghum, molasses and waste rice had more pronounced affects, increasing $\mathrm{CH}_{4}$ production rate by approximately $90 \%$. 


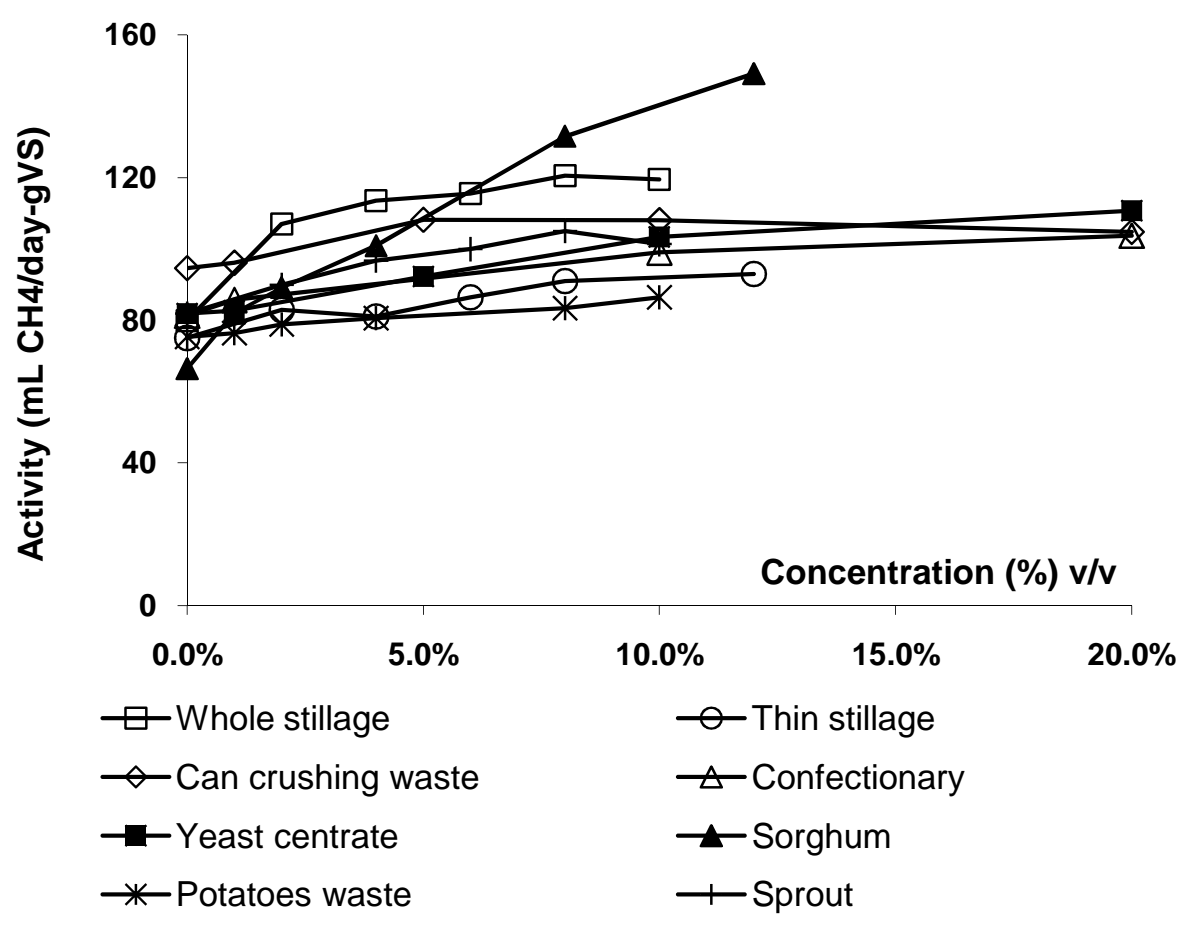

Figure 1.9: (a) Synergistic outcomes

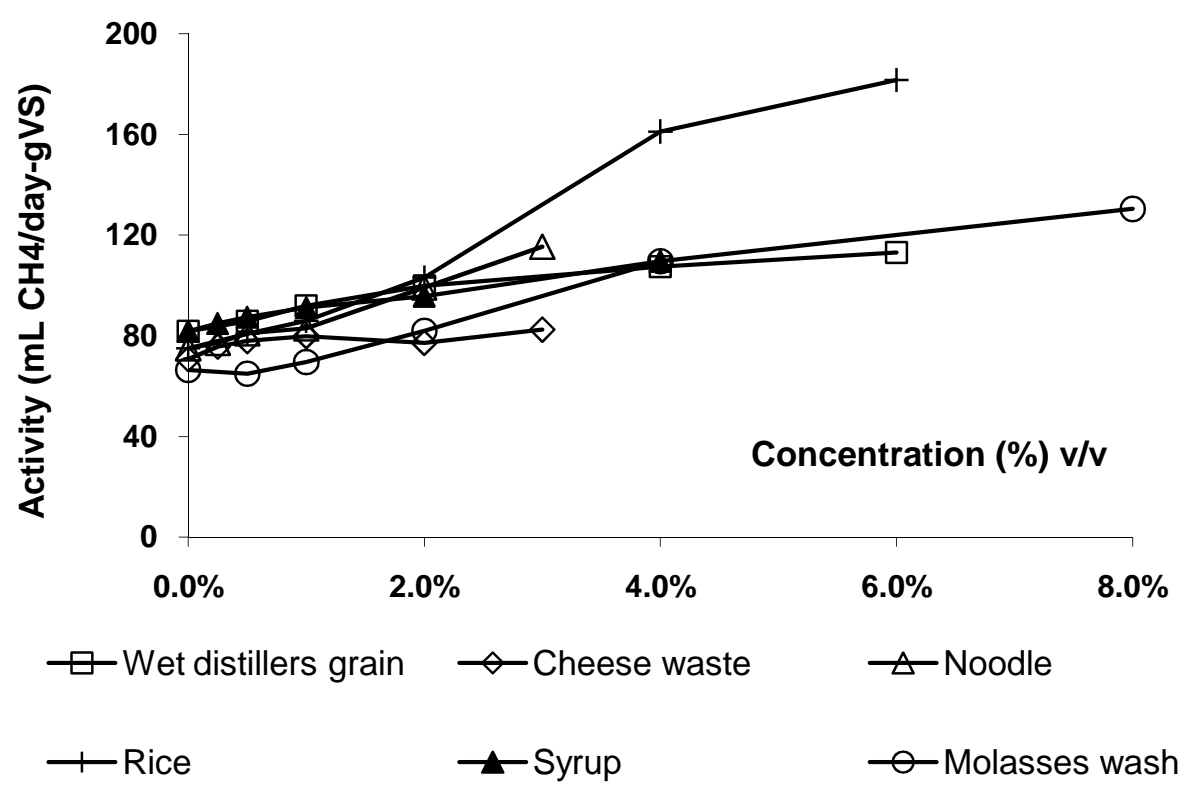

Figure 1.9: (b) Synergistic outcomes 


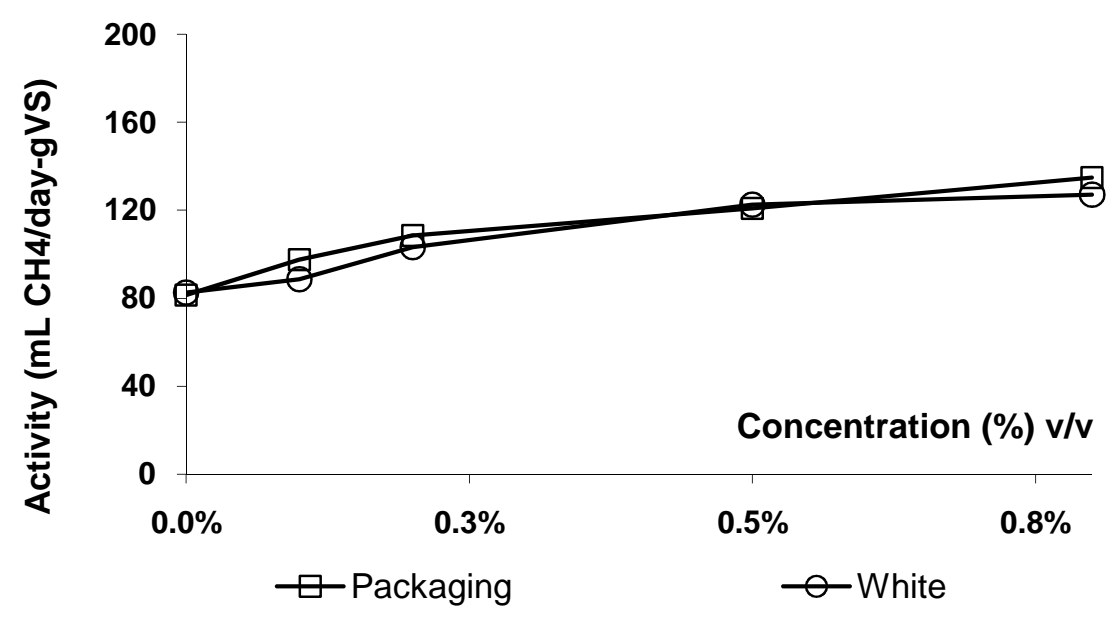

Figure 1.9: (c) Synergistic outcomes

Antagonism was observed for soap waste $\left(\mathrm{IC}_{50}=2 \%\right)$, boiler cleaning wastewater $\left(\mathrm{IC}_{50}=\right.$ 9.5\%), metal cutting waste $\left(\mathrm{IC}_{50}=12 \%\right)$, oil and hydraulic fluids waste $\left(\mathrm{IC}_{50}>15 \%\right)$, cookie waste $\left(\mathrm{IC}_{50}>50 \%\right)$, lettuce waste $\left(\mathrm{IC}_{50}=25 \%\right)$, cabbage waste $\left(\mathrm{IC}_{50}>25 \%\right)$, mustard waste $\left(\mathrm{IC}_{50}=14.4 \%\right)$, compost $\left(\mathrm{IC}_{50}>6 \%\right)$, corrugated cardboard $\left(\mathrm{IC}_{50}=1.1 \%\right)$ and dried manure $\left(\mathrm{IC}_{50}>3 \%\right.$ ) (see Figure 1.10 (a) and (b)). Antagonistic outcomes may have been caused by inhibitory concentrations of zinc $(50 \mathrm{mg} / \mathrm{L})$ in soap and copper (68 $\mathrm{mg} / \mathrm{L})$, zinc $(18 \mathrm{mg} / \mathrm{L})$ and chromium $(6.9 \mathrm{mg} / \mathrm{L})$ in boiler cleaning waste. The inhibitory substances in other wastes are unknown. 


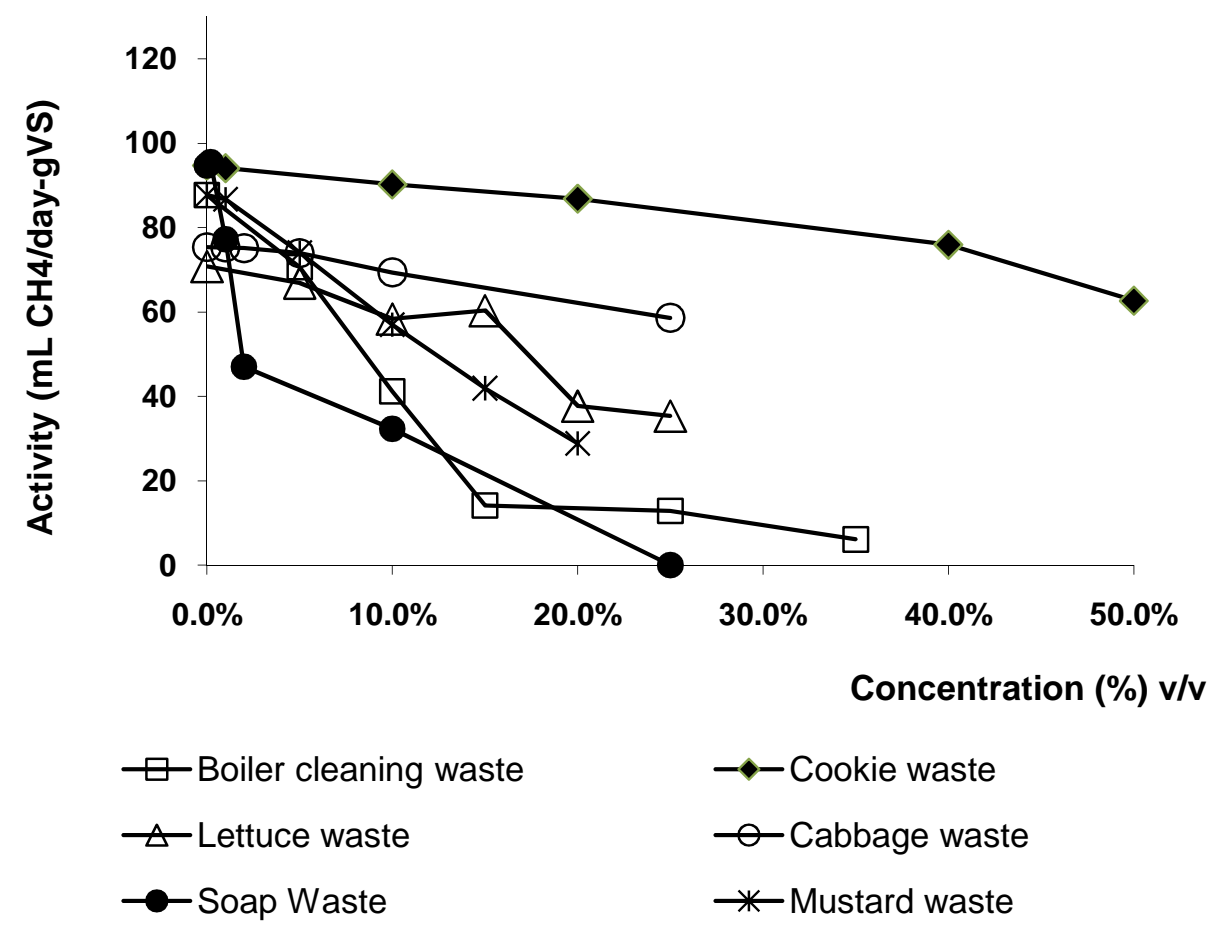

Figure 1.10: (a) Antagonistic outcomes

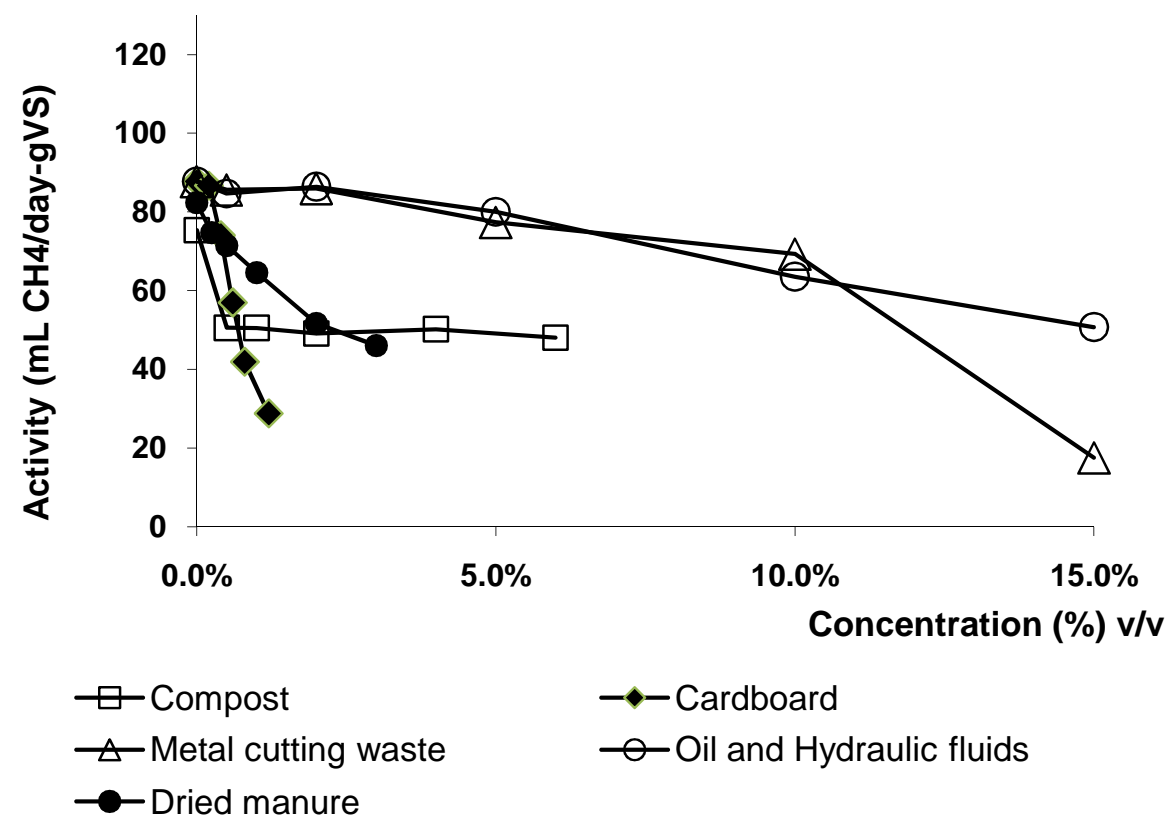

Figure 1.10: (b) Antagonistic outcomes 
Neutral outcomes were observed for float, acid whey, paunch, brewery grain, algae (botrycoccus braunii), algae (nannochloropsis), heads from rum distillation, cooking solids, wood chip/charcoal, corn stover, dewatered paper mill sludge, cocoa husks and pre-filter slurry (see Figure 1.11 (a), (b), and (c)). However, acid whey resulted in a synergetic outcome in subsequent studies (BMP test with synthetic primary sludge and full-scale test with primary sludge) which is described later in this chapter.

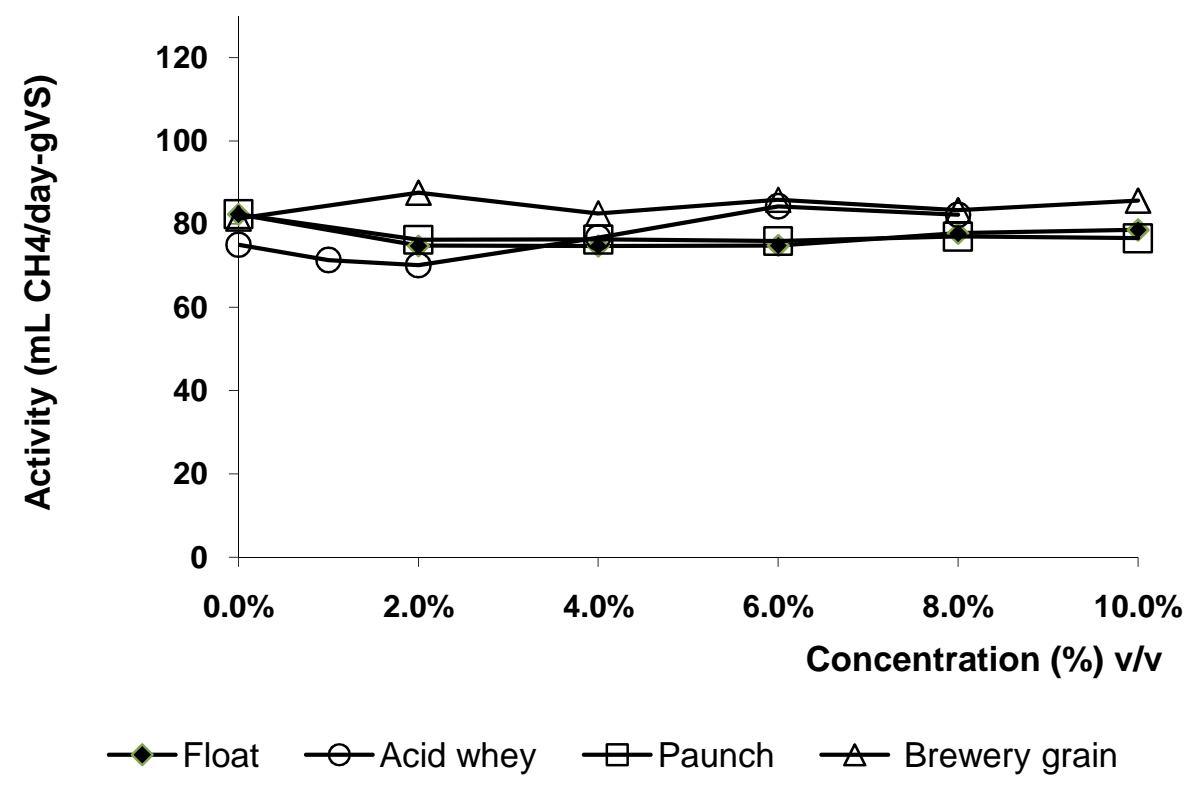

Figure 1.11: (a) Neutral outcomes 


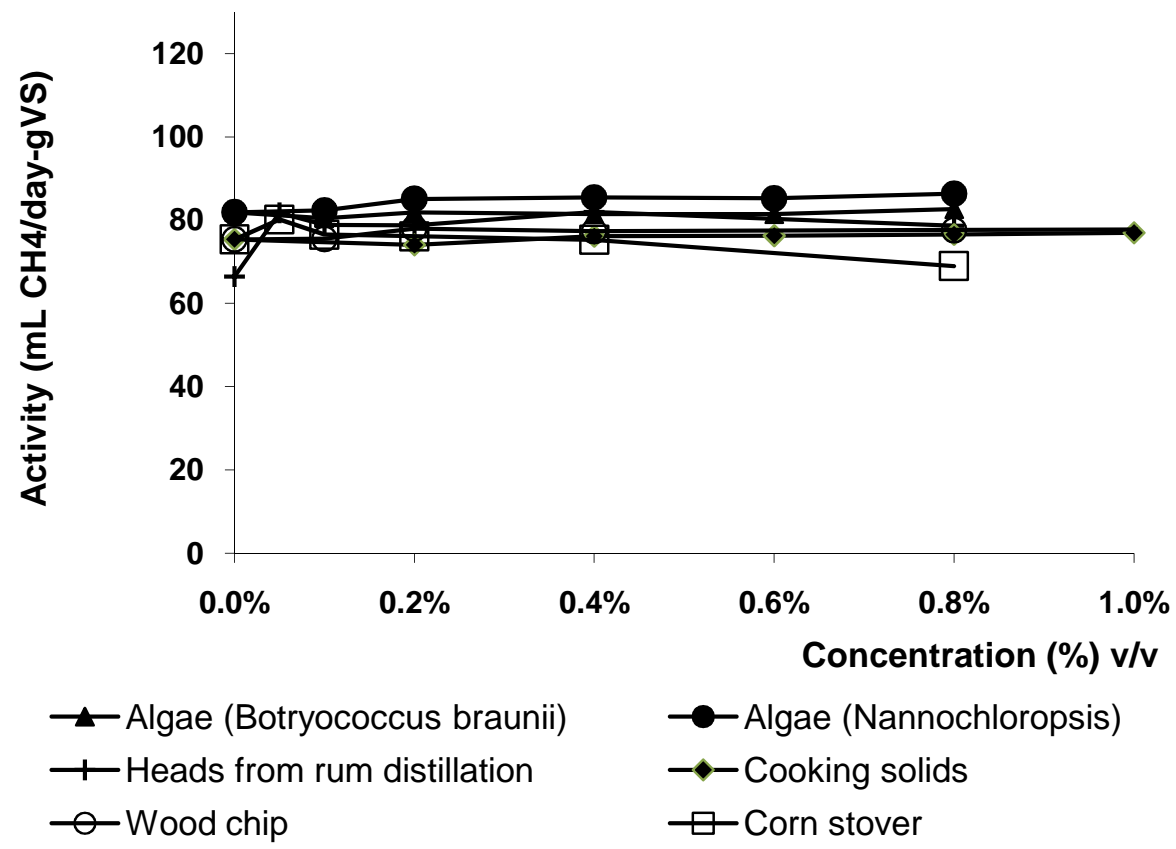

Figure 1.11: (b) Neutral outcomes

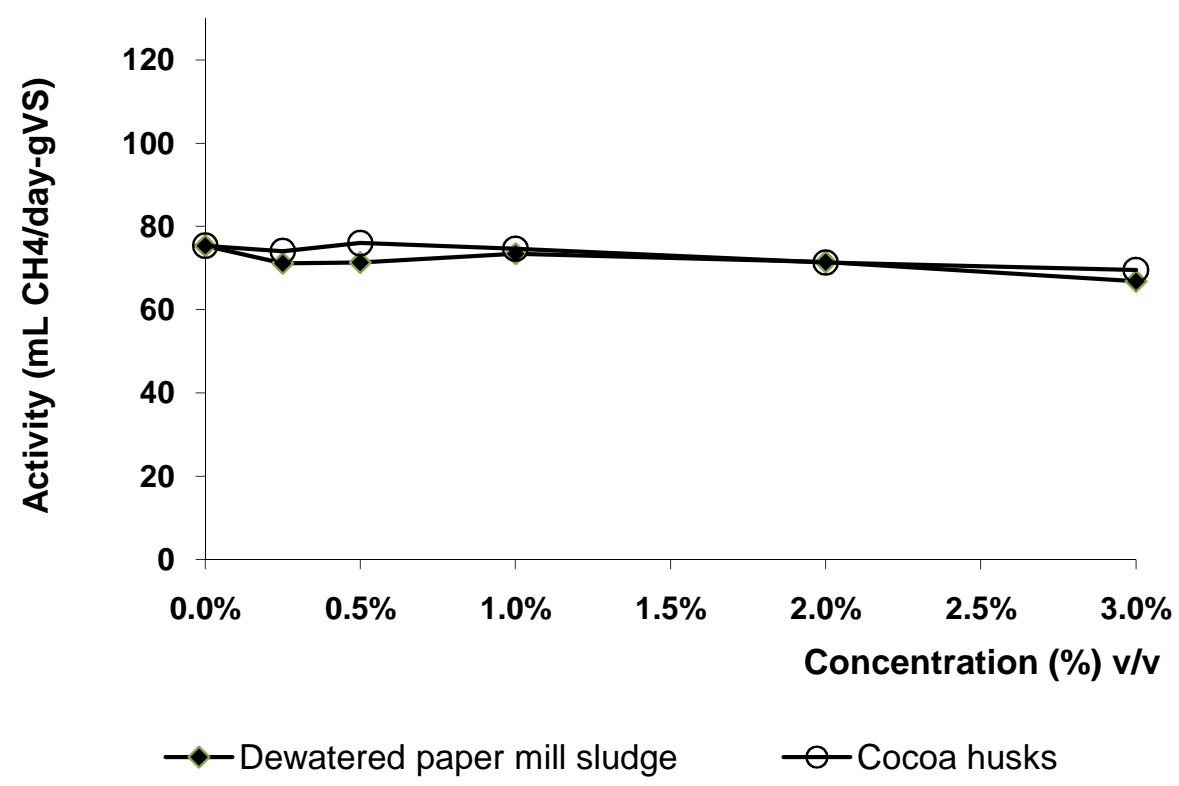

Figure 1.11: (c) Neutral outcomes 
Some wastes such as flavorings yeast, trube, brewery yeast, pine apple, corn/rye/wheat/barley in liquid, FT reactor condensate demonstrated mixed outcomes, with a synergistic effect observed at low concentrations and an antagonistic effect observed at higher concentrations (see Figure 1.12 (a) and (b)).

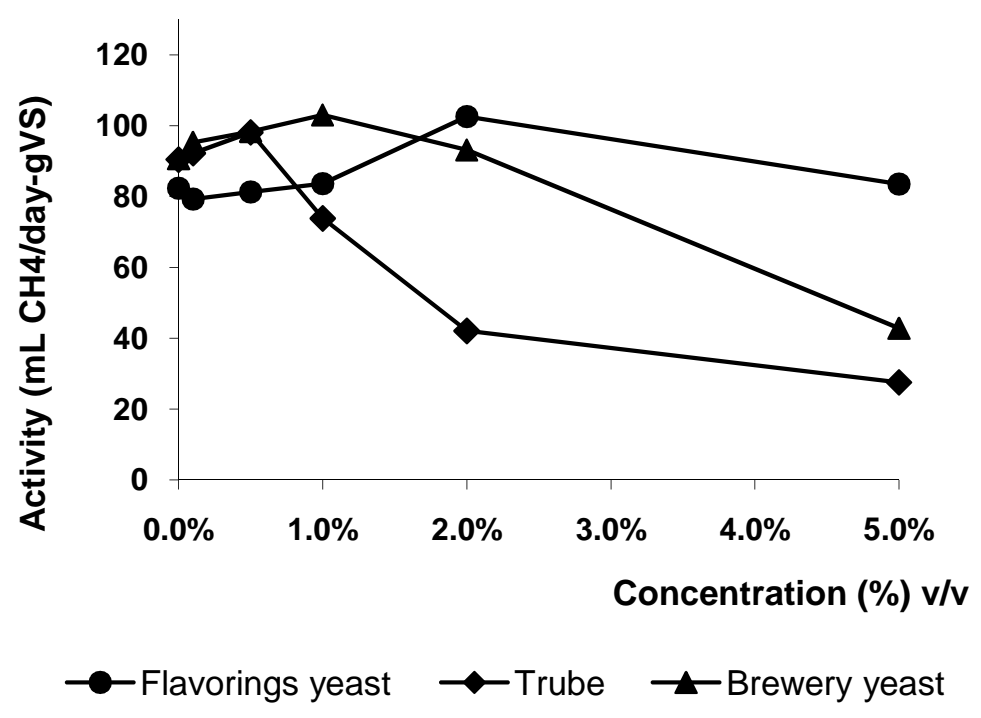

Figure 1.12: (a) Mixed outcomes

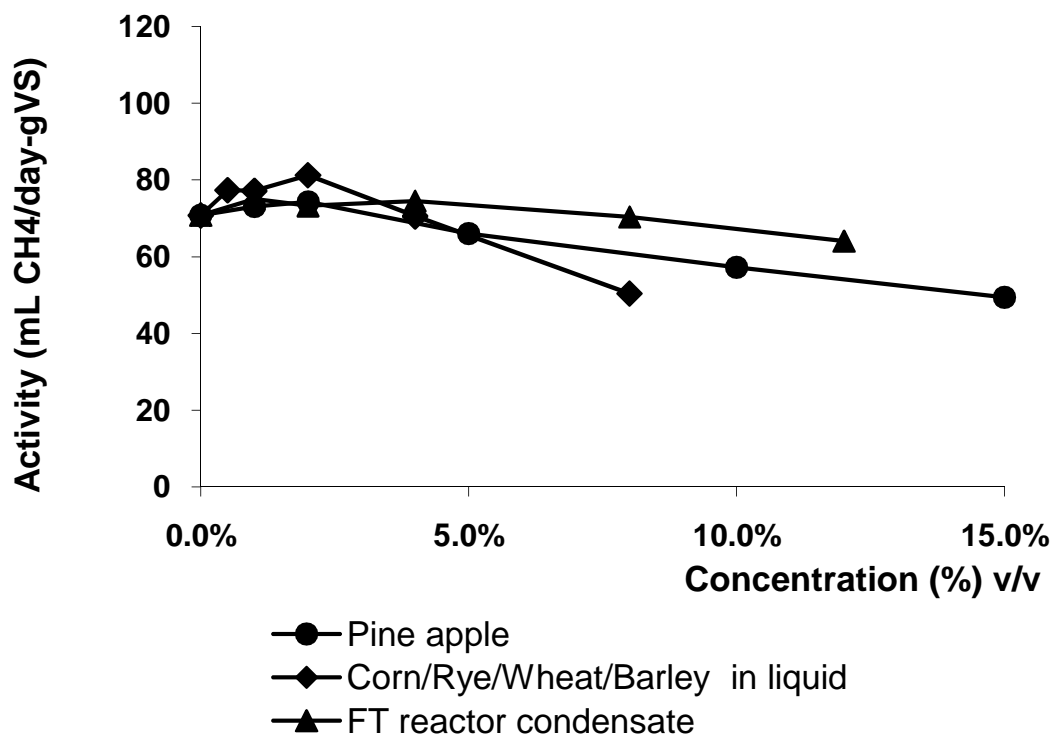

Figure 1.12: (b) Mixed outcomes 


\subsubsection{Sieve analysis}

The $\mathrm{d}_{10}$ (sieve opening size passing $10 \%$ of the material), $\mathrm{d}_{50}$ and $\mathrm{d}_{90}$ were calculated from the plots of percent passing verse sieve size. The values for $d_{10}, d_{50}$ and $\mathrm{d}_{90}$ are presented in Table 1.7 (summary of wastes characteristics). The $\mathrm{d}_{90}$ for wastes which were selected for bench scale co-digestion (float, flavorings yeast, thin stillage, acid whey and can crushing wastes) were less than $0.075 \mathrm{~mm}$ except float waste. It was $0.52 \mathrm{~mm}$ for float waste. The advantages of selecting waste with fine particle sizes were avoidance of grinding of waste as pretreatment, less settling of particiles in the available, but unmixed storage tank at SSWRF and easy mixing with primary sludge.

\subsubsection{Cost-benefit analysis}

The cost benefit calculations for 46 wastes are presented in Table A.1 of Appendix A. Only 22 wastes were considered for further screening due to limitation and capability of the existing equipment including pump, mixer at the SSWWRF during period of this study. The net benefits for 22 wastes are presented in Figure 1.13. The economic analysis resulted in high positive benefits (> $50 \$ / \mathrm{m}^{3}$ of waste) for eight of the 22 co-digestates: (1) heads from rum distillation, (2) syrup, (3) brewery yeast, (4) flavorings yeast, (5) trube, (6) float, (7) corn/rye/wheat/barley in liquid and (8) whole stillage. However, to select co-digestates for further study, other waste characteristics were considered, including the volume of waste produced, the probable reliability of waste availability over time, apparent toxicity, and availability of other sustainable disposal methods (i.e., sale as animal feed or food additive). Based upon all factors, the 
five most promising wastes for further bench- and pilot-scale testing were as follows: (1) float, (2) flavorings yeast, (3) thin stillage, (4) acid whey and (5) soft drinking can crushing waste. Even though the net benefits of trube and brewery yeast were positive, these wastes were not included in pilot testing due to low production volume and existing worth as a food product, respectively. Heads from rum distillation, corn/rye/wheat/barley in liquid, molassess wash and sorghum were not included in pilot testing due low production volume (<20 gpd). Among the four corn ethanol wastes (wet distillers grain, whole stillage, thin stillage and syrup), thin stillage was selected for further study since alternative disposal options were available for whole stillage by separating wet distillers grain (animal feed) and a significant amount of energy is required to produce syrup (syrup is produced from thin stillage by evaporating the water). Oil and hydrolic fluids was not selected because of their antagonistic outcomes. The net benefit of FT reactor condensate was negative because of the high shipping cost resulted from the long distance $(1500 \mathrm{~km})$ between the source of waste and the wastewater treatment facility. 


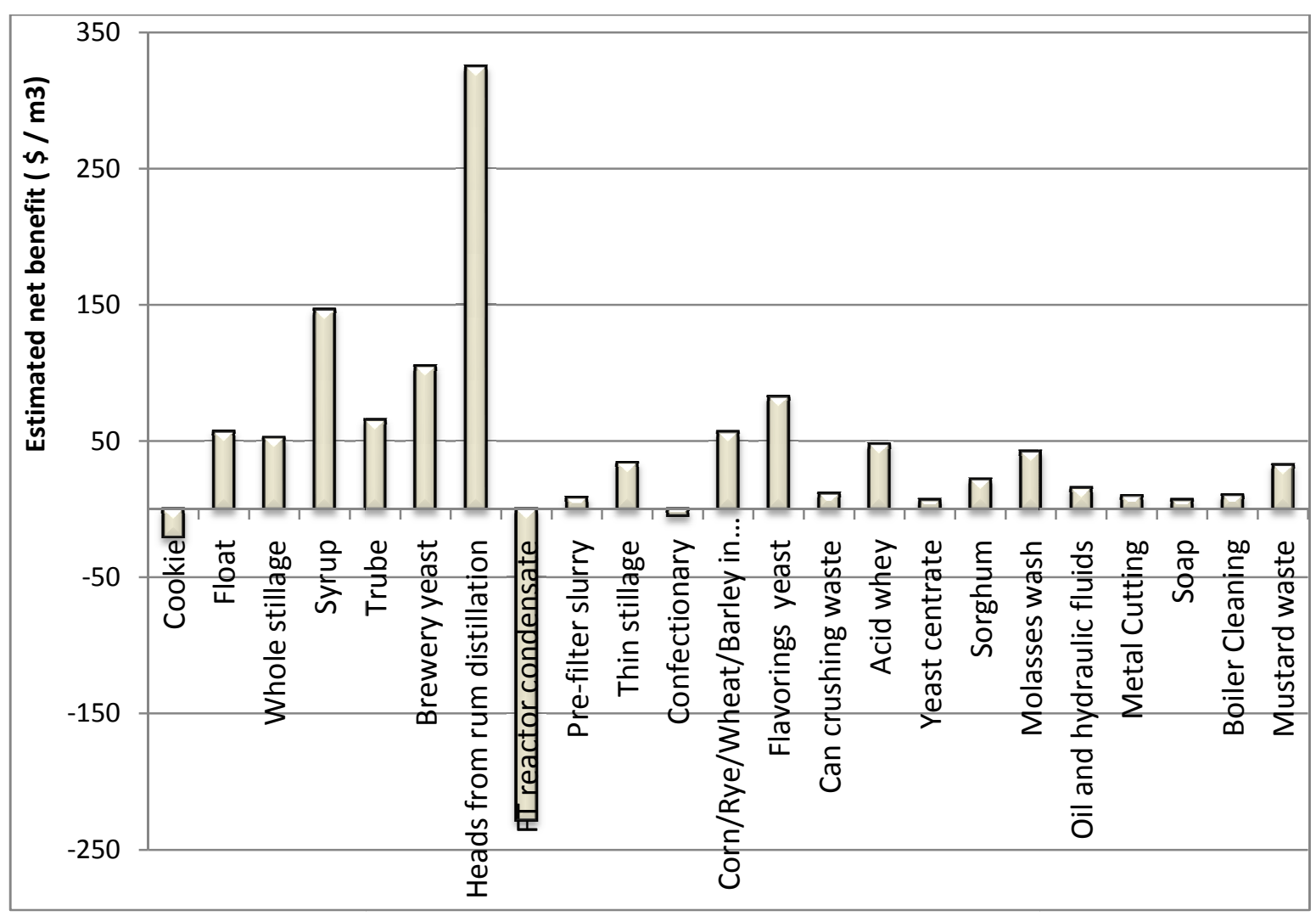

Figure 1.13: Co-digestate cost-benefit analysis results

\subsubsection{Performance of bench-scale anaerobic digesters}

The performance of bench-scale co-digesters is described below.

\subsubsection{1 $\mathrm{CH}_{4}$ production and biogas composition}

The average $\mathrm{CH}_{4}$ production rates of Control, Co-Digester 1 and Co-Digester 2 systems are presented in Figure 1.14. The $\mathrm{CH}_{4}$ production rates of all six digesters between Days 45 and 55 were approximately equal. During the co-digestion period (Days 55 to 100$), \mathrm{CH}_{4}$ production rates of Co-Digester 1 and 2 systems increased by $105 \%$ and $66 \%$ in comparison to the Control systems, respectively. When extra organic carbon was added to co-digesters, the $\mathrm{CH}_{4}$ production rate was expected to increase. But the extra 
$\mathrm{CH}_{4}$ production from the additional co-digestate carbon was theoretically anticipated to be only $57 \%$ and $23 \%$ greater from Co-Digester systems 1 and 2, respectively (see Table 1.8). The theoretical $\mathrm{CH}_{4}$ production rate was the anticipated $\mathrm{CH}_{4}$ production from the co-digestates, which was calculated from the corresponding BMP value of the waste.

There was a significant synergistic effect when the wastes were co-digested.

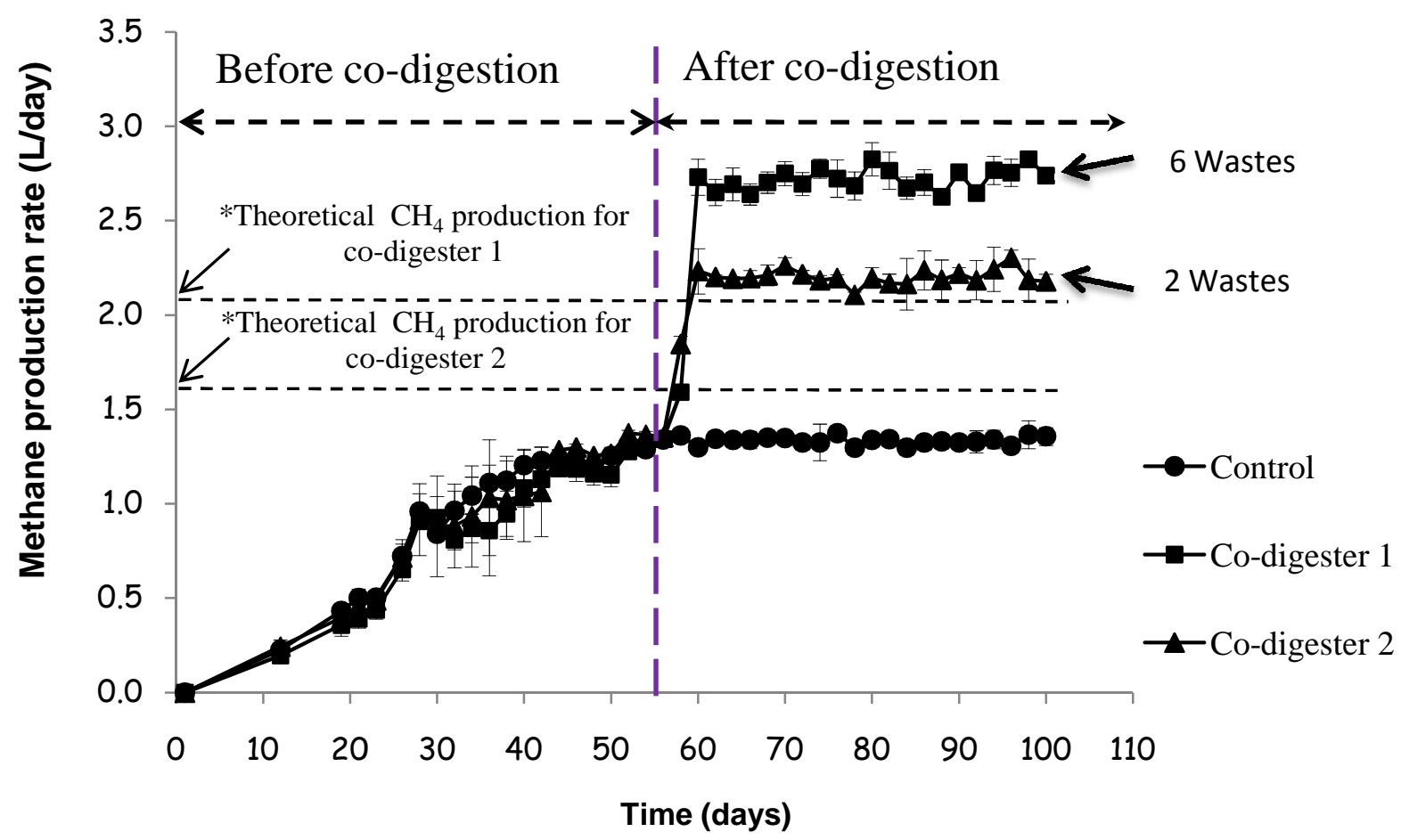

Figure 1.14: $\mathrm{CH}_{4}$ production rate of digesters

Theoretical $\mathrm{CH}_{4}$ production $=\mathrm{CH}_{4}$ production from control + theoretical $\mathrm{CH}_{4}$ production of co-digestates which was calculated using BMP values of co-digstates 
Table 1.8: Methane production due to synergism of co-digestion

\begin{tabular}{lccc}
\hline & Control & Co-Digester 1 & Co-Digester 2 \\
\hline Actual $\mathrm{CH}_{4}$ production (L/day) & $1.33 \pm 0.02$ & $2.73 \pm 0.06$ & $2.21 \pm 0.04$ \\
Theoretical $\mathrm{CH}_{4}$ from co-digestates (L/day) & 0 & $0.76 \pm 0.02$ & $0.31 \pm 0.04$ \\
\% extra $\mathrm{CH}_{4}$ from co-digestates in comparison & - & $57 \pm 2 \%$ & $23 \pm 3 \%$ \\
to Control & $1.33 \pm 0.02$ & $2.09 \pm 0.06$ & $1.64 \pm 0.06$ \\
$\begin{array}{l}\text { Theatrical total } \mathrm{CH}_{4} \text { (L/day) } \\
\text { excess } \mathrm{CH}_{4} \text { due to the synergism (L/day) }\end{array}$ & 0 & $0.64 \pm 0.08$ & $0.57 \pm 0.07$ \\
$\begin{array}{l}\% \text { Excess } \mathrm{CH}_{4} \text { due to the synergism in } \\
\text { comparison to Control }\end{array}$ & - & $48 \pm 6 \%$ & $42 \pm 5 \%$ \\
\hline
\end{tabular}

\subsubsection{Biogas methane composition}

The biogas $\mathrm{CH}_{4}$ content was $62 \pm 1 \%$ under all three digester conditions.

\subsubsection{TS and VS destruction}

The VS content of the digested sludge from the Control, Co-Digester 1 and CoDigester 2 systems are presented in Figure 1.15. Average effluent VS concentrations for all the three systems between days 45 and 55 were to around $1 \%$. After steady state with co-digestion, TS removal efficiency of the Control, Co-Digester 1 and Co-Digester 2 systems were $46 \pm 2 \%, 73 \pm 3 \%$ and $61 \pm 3 \%$, respectively. VS removal efficiency of the Control, Co-Digester 1 and Co-Digester 2 systems were $58 \pm 2 \%, 88 \pm 3 \%$ and $78 \pm 2 \%$, respectively. The TS and VS removal efficiencies of Co-Digesters 1 and 2 increased by $49 \pm 6$ and $33 \pm 5$, respectively, in comparison to the control systems. 


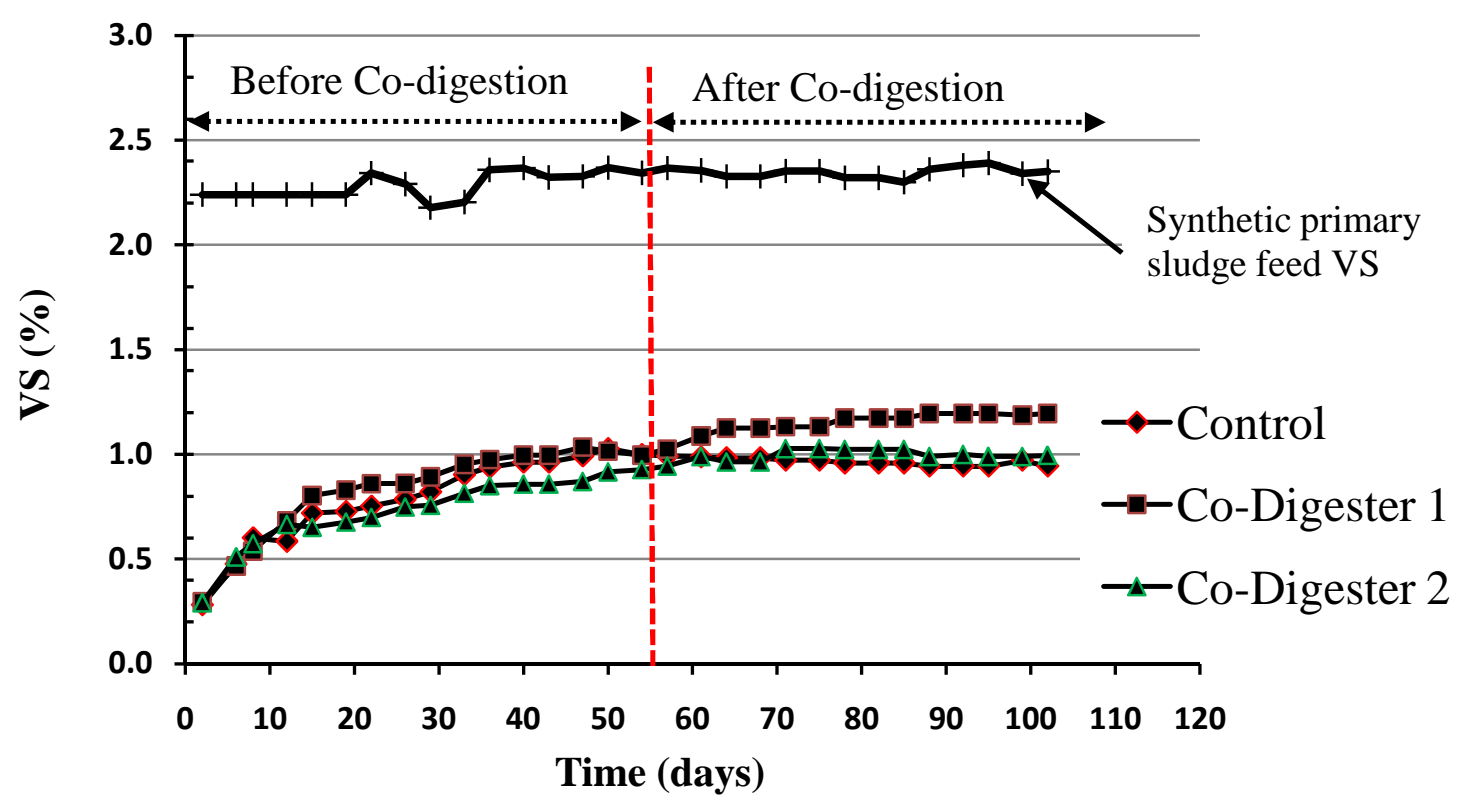

Figure 1.15: VS of digested sludge versus operation time

\subsubsection{Other effluent values}

The values for $\mathrm{pH}$, total VFA, alkalinity, soluble COD and soluble TOC for all three conditions are listed in Table 1.9. The parameters, $\mathrm{pH}$, total VFA, alkalinity and SCOD in Table 1.9 were not statistically different among the three digester systems. TSS and VSS were statistically different between Control and Co-Digester 1 systems, whereas not statistically different between Control and Co-Digester 2 systems. The Soluble TOC was statistically different among the three digester systems. 
Table 1.9: Effluent values for all three conditions

\begin{tabular}{lccc}
\hline Parameters & Control & Co-Digester 1 & Co-Digester 2 \\
\hline $\mathrm{pH}$ & $7.2-7.3$ & $7.2-7.3$ & $7.2-7.3$ \\
Total VFA (eq/L) & $0.29 \pm 0.14$ & $0.23 \pm 0.16$ & $0.30 \pm 0.10$ \\
Alkalinity (mg/L as CaCO3) & $6000 \pm 50$ & $6010 \pm 40$ & $5990 \pm 70$ \\
SCOD(mg/L) & $970 \pm 90$ & $1160 \pm 110$ & $980 \pm 110$ \\
Soluble TOC (mg/L) & $940 \pm 20$ & $1142 \pm 20$ & $1030 \pm 30$ \\
TSS (g/L) & $9.83 \pm 0.27$ & $12.9 \pm 0.8$ & $9.95 \pm 0.70$ \\
VSS (g/L) & $8.36 \pm 0.44$ & $10.8 \pm 0.4$ & $8.38 \pm 0.74$ \\
\hline
\end{tabular}

\subsubsection{5 $\mathrm{NH}_{3}-\mathrm{N}$ and TKN}

Effluent $\mathrm{NH}_{3}-\mathrm{N}$ and TKN concentrations under all three conditions were between 910-1050 mg/L and 1510-1860 mg/L respectively (see Figure 1.16 (a) and (b)). The Average $\mathrm{TKN} / \mathrm{NH}_{3}-\mathrm{N}$ ratio was 1.7 . Average $\mathrm{NH}_{3}-\mathrm{N}$ and $\mathrm{TKN}$ concentrations, in order from highest to lowest were as follows: Co-Digester $2>$ Co-Digester $1>$ Control.

However, $\mathrm{NH}_{3}-\mathrm{N}$ and TKN concentrations in the Control and Co-Digester 1 systems were not significantly different, whereas those of the Control and Co-Digester 2 systems were different at a $99 \%$ level of significance.

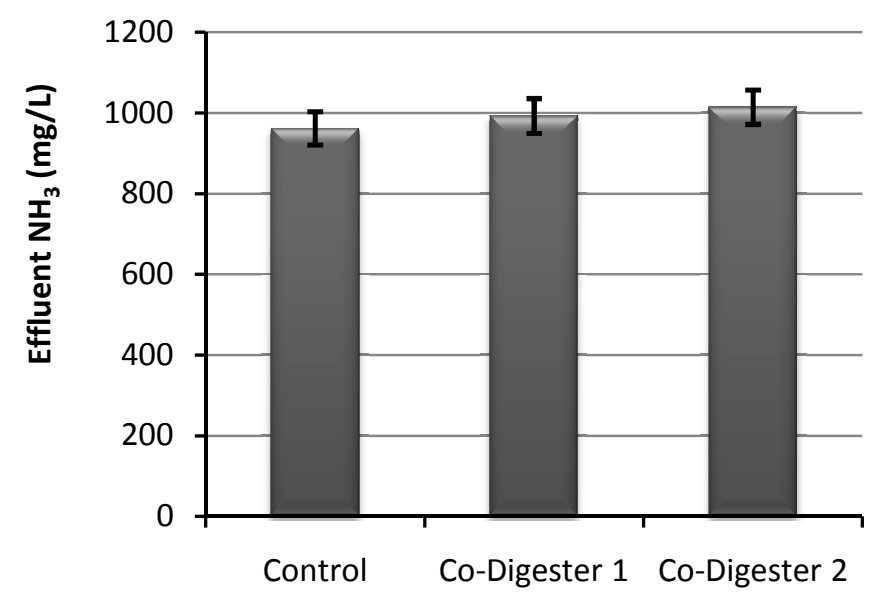

Figure 1.16: (a) Effluent $\mathrm{NH}_{3}-\mathrm{N}$ concentration under three conditions 


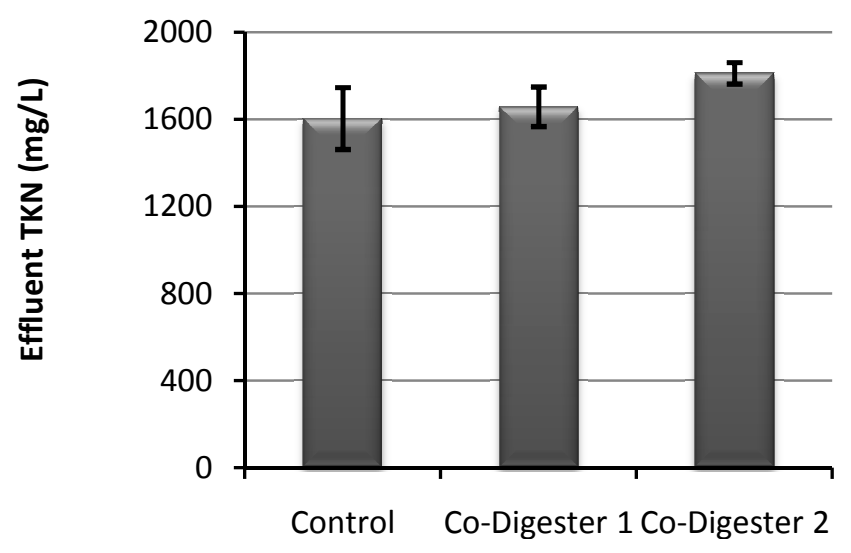

Figure 1.6: (b) Effluent TKN concentration under three conditions

\subsubsection{Estimated benefit of full scale co-digestion based on bench-scale digester}

Bench-scale digester results were used to estimate the energy production and $\mathrm{CO}_{2}$ avoidance for full-scale co-digestion (see Table 1.10). The full-scale Co-Digester 1 scenario involves a feed volume including $1890 \mathrm{~m}^{3} / \mathrm{d}$ primary sludge, $38 \mathrm{~m}^{3} / \mathrm{d}$ float, 12 $\mathrm{m}^{3} / \mathrm{d}$ flavorings yeast, $61 \mathrm{~m}^{3} / \mathrm{d}$ thin stillage, $45 \mathrm{~m}^{3} / \mathrm{d}$ acid whey, and $36 \mathrm{~m}^{3} / \mathrm{d}$ can crushing waste. The Co-Digester 2 scenario involves a feed volume including $1890 \mathrm{~m}^{3} / \mathrm{d}$ primary sludge and $12 \mathrm{~m}^{3} / \mathrm{d}$ flavorings yeast. Co-digester 1 and 2 scenarios were estimated to result in a decrease in net $\mathrm{CO}_{2}$ emissions assuming that biogas replaces coal as fuel (see Table 1.10). The additional electricity generated from Co-Digester 1 and 2 scenarios was estimated to be enough to power more than 2500 and 340 houses, respectively. However, actual full-scale energy production and $\mathrm{CO}_{2}$ emissions may vary due to other factors. 
Table 1.10: Estimated energy production and $\mathrm{CO}_{2}$ avoidance

\begin{tabular}{|c|c|c|c|}
\hline & Control & Co-Digester 1 & Co-Digester 2 \\
\hline Primary sludge flow ( $\mathrm{m}^{3} /$ day) & 1890 & 1890 & 1890 \\
\hline Co-digestate flow ( $\mathrm{m}^{3} /$ day) & 0 & 192 & 12 \\
\hline Total $\mathrm{CH}_{4}(\mathrm{ML} /$ day $)$ & 15.1 & 34.1 & 17.7 \\
\hline $\mathrm{CH}_{4}$ energy $(1000 \mathrm{MJ} / \text { day })^{\mathrm{a}}$ & 530 & 1190 & 620 \\
\hline $\begin{array}{l}\text { Estimated } \mathrm{CO}_{2} \text { emissions avoidance } \\
\text { (tonnes/year) }\end{array}$ & 17000 & 38200 & 19900 \\
\hline $\begin{array}{l}\text { Average U.S. homes provided electricity } \\
\text { (houses) }\end{array}$ & 2000 & 4500 & 2340 \\
\hline
\end{tabular}

${ }^{\mathrm{a}}$ Assuming $\mathrm{CH}_{4}$ heat content of $0.035 \mathrm{MJ} / \mathrm{L} \mathrm{CH}_{4}$ at $35^{\circ} \mathrm{C}\left(930 \mathrm{BTU} / \mathrm{ft}^{3}\right)$

${ }^{\mathrm{b}}$ Assuming switching from bituminous coal and coal emissions factor of $0.088 \mathrm{~kg} \mathrm{CO}_{2} / \mathrm{MJ}$ (Hong and Slatick, 1994)

${ }^{\mathrm{c}}$ Assuming average U.S. household electricity usage of $90 \mathrm{MJ} / \mathrm{d}(25 \mathrm{kWh} / \mathrm{d})$ and biogas-to-electricity conversion efficiency of 34\% (10000 Btu/kWh) (Speece,1996)

\subsubsection{Specific methanogenic activity (SMA) of biomass}

The SMA values of biomass from each of the six bench-scale digesters were calculated from triplicate assays. The SMAs for the duplicate digesters in each system were not statistically different. Therefore, all six SMA measurements for each system were averaged. The SMAs against each substrate (acetate, propionate and hydrogen) are described below.

\subsubsection{SMA against acetate and propionate}

The SMAs against acetate as a substrate are presented in Figure 1.17. Error bars represent the standard deviation of the six SMAs for each system. The highest SMA values were obtained for the biomass taken from the Co-Digester 1 systems, whereas CoDigester 2 biomass also demonstrated SMA values higher than the Control systems. The increases in average SMA value of the biomass due to co-digestion were $19 \pm 9 \%$ and $18 \pm 9 \%$ for Co-Digester 1 and 2 systems, respectively, compared to the Control systems. 
The SMAs were statistically different at the 99\% significance level between Control and Co-Digester $1(\mathrm{~F}(1,10)=31$ and $\alpha<0.001)$ as well as Control and Co-Digester 2(F (1, 10) $=28.9$ and $\alpha<0.001)$.

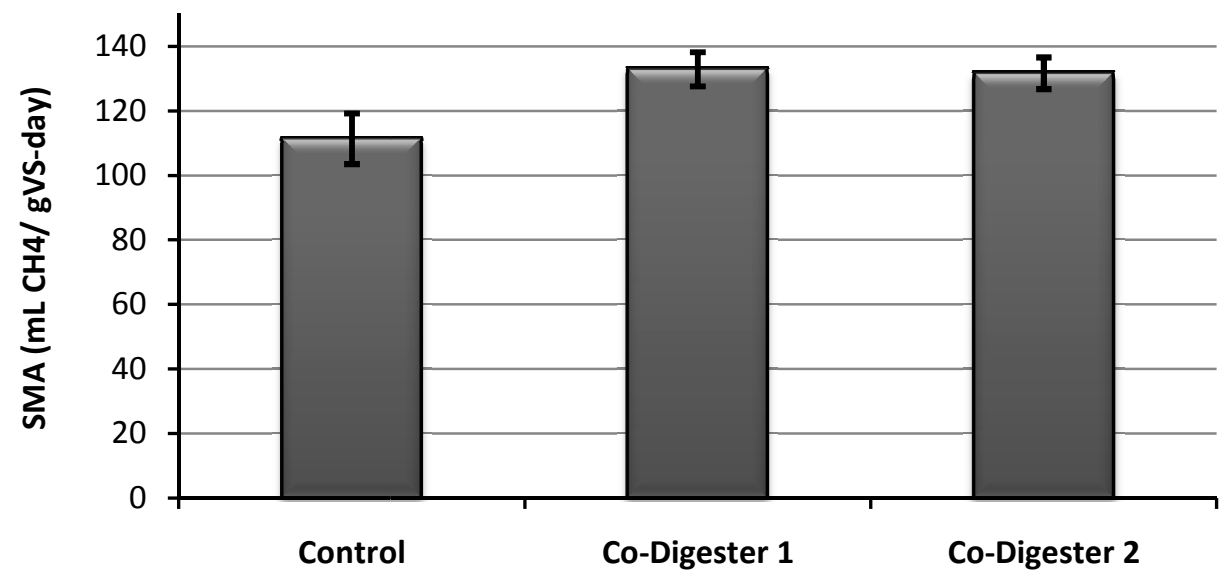

Figure 1.17: SMA results against acetate of the different conditions

The SMAs against propionate as a substrate are presented in Figure 1.18. Error bars represent the standard deviation of the six SMAs for each condition. Higher SMAs were obtained for the biomass taken from Co-Digester 1 and 2 systems. The increases in SMAs of the biomass due to co-digestion were $27 \pm 12 \%$ and $32 \pm 16 \%$ for the CoDigester 1 and 2 systems, respectively, compared to the control. The average SMA values were statistically different at the $99 \%$ significance level between Control and CoDigester $1(\mathrm{~F}(1,10)=31.8$ and $\alpha<0.001)$ as well as Control and Co-Digester 2(F $(1,10)$ $=26.6$ and $\alpha<0.001$ ). 


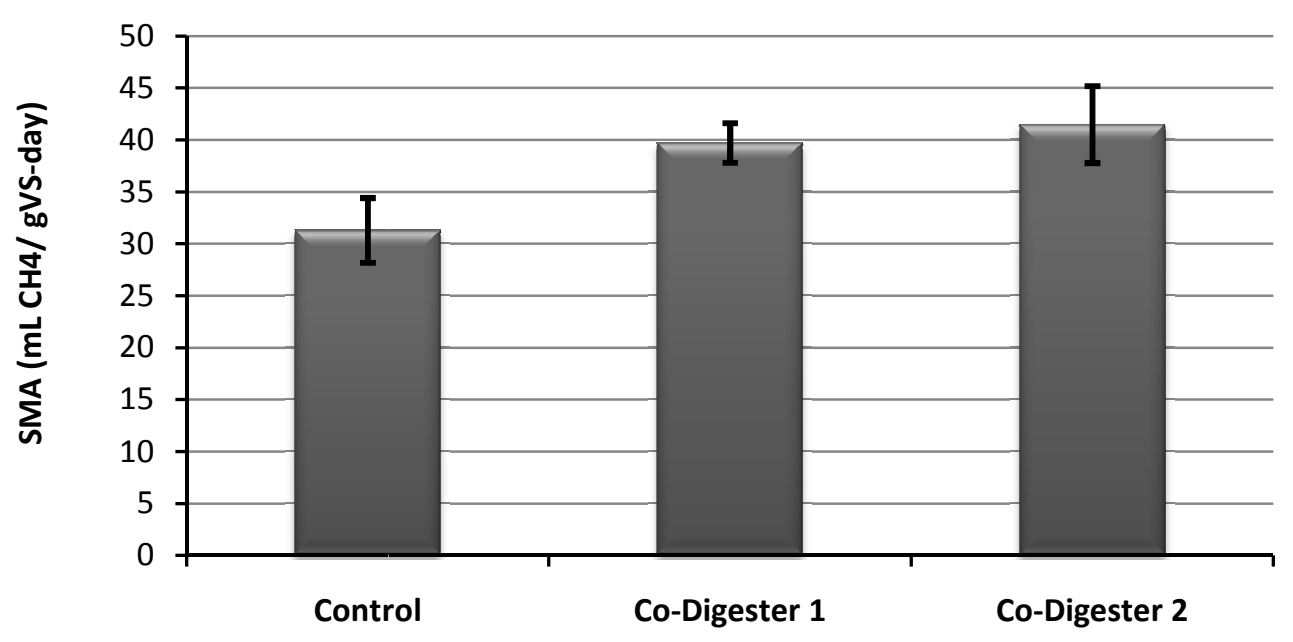

Figure 1.18: SMA results against propionate of the different conditions

\subsubsection{SMA against $\mathrm{H}_{2}$}

The SMAs against $\mathrm{H}_{2}$ as a substrate are presented in Figure 1.19. Error bars represent standard deviation of the six SMAs for each condition. The higher SMAs were obtained for the biomass taken from the Co-Digester 1 and 2 systems. The increases in SMA values of the biomass due to co-digestion were $36 \pm 19 \%$ and $15 \pm 25 \%$ for CoDigester 1 and 2 systems, respectively, compared to the Control. The SMAs were statistically different at the $99 \%$ significance level between Control and Co-Digester 1 systems $(\mathrm{F}(1,10)=22.5$ and $\alpha=0.001)$, whereas the SMAs were not statistically different at the $95 \%$ significance level between the Control and Co-Digester 2 systems (F $(1,10)=2.3$ and $\alpha=0.16)$. 


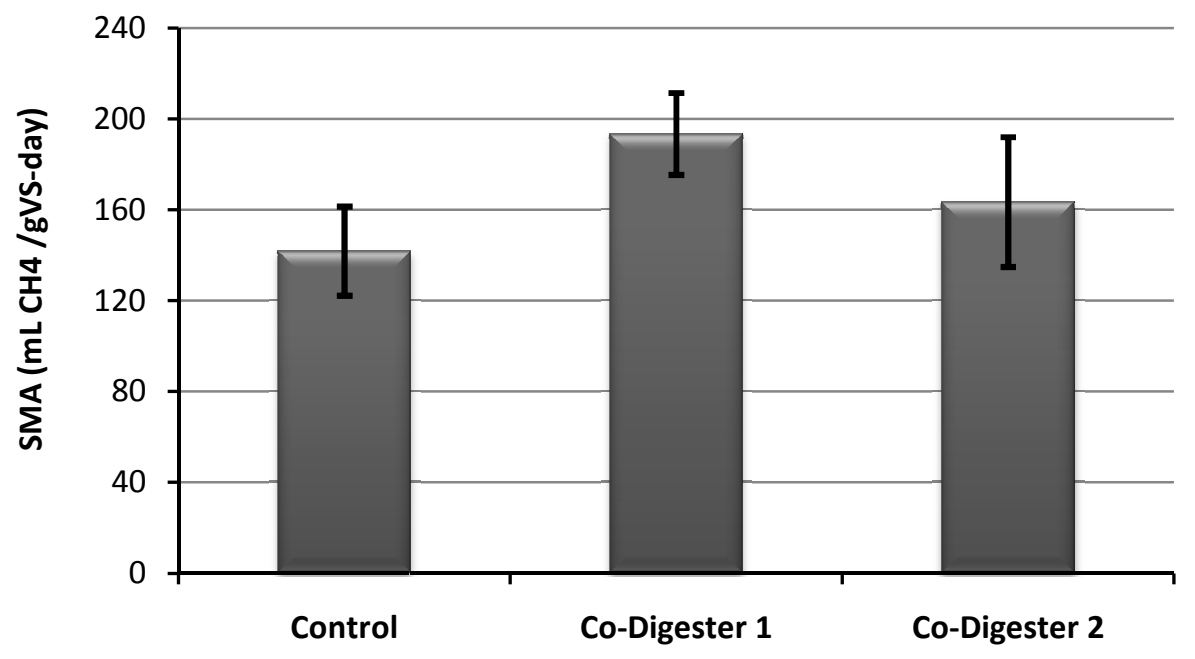

Figure 1.19: SMA results against $\mathrm{H}_{2}$ of the biomass from the different digesters

In three cases, the SMA values against acetate, propionate and $\mathrm{H}_{2}$, the SMAs of biomass in the co-digesters increased compared to that of the controls. The reasons for increased SMAs may be either an increase in the total number of microbes present in codigesters (but the same general microbial community structure), the establishment of a new microbial community structure in co-digesters, or both. The microbial community structures in different digesters can be compared using molecular techniques like denaturing gradient gel electrophoresis (DGGE), quantitative polymerase chain reaction (qPCR) or other methods. The relationship among DGGE banding pattern of methyl coenzyme M reductase (mcrA) genes and increased SMAs is described in the Chapter 2. The increase in SMA may be a cause for synergistic outcomes in the co-digesters. 


\subsubsection{Synergistic, antagonistic and neutral outcomes for different wastes}

The BMP results for single and mixtures of two wastes are presented in Table 1.11. High BMP values were observed for these wastes except for the BMP of metal cutting waste and metal cutting waste with synthetic primary sludge.

Table 1.11: BMP results for single and mixed wastes

\begin{tabular}{|c|c|c|}
\hline Samples & $\begin{array}{c}\text { Average } \\
\mathrm{CH}_{4} \mathrm{~mL} / \mathrm{g} \mathrm{COD} \\
\end{array}$ & $\begin{array}{c}\text { Std-deviation } \\
\mathrm{CH}_{4} \mathrm{~mL} / \mathrm{g} \text { COD }\end{array}$ \\
\hline Flavorings & 318 & 16 \\
\hline Thin stilllage & 364 & 7 \\
\hline Acid whey & 347 & 5 \\
\hline Can crushing & 338 & 8 \\
\hline Metal cutting & 117 & 5 \\
\hline Float & 390 & 8 \\
\hline synthetic primary sludge & 367 & 13 \\
\hline synthetic primary sludge + Flavorings & 386 & 9 \\
\hline synthetic primary sludge + Thin stillage & 394 & 6 \\
\hline synthetic primary sludge + Acid whey & 387 & 6 \\
\hline synthetic primary sludge + Can crushing & 391 & 7 \\
\hline synthetic primary sludge + Metal cutting & 218 & 10 \\
\hline synthetic primary sludge + Float & 383 & 6 \\
\hline
\end{tabular}

For actual BMP values determined for mixed wastes, a 50/50 mass blend based on COD was tested. Theoretical BMP values of the mixed wastes (i.e., the sum of $50 \%$ of the BMP values of each waste in the mix) were also calculated. Both the actual BMP and theoretical BMP values for each waste mix are presented in Figure 1.20. The actual BMP value of mixed waste was $13 \pm 7 \%$ greater than the theoretical value for flavorings waste, $11 \pm 5 \%$ for can crushing waste, and $8 \pm 4 \%$ greater for acid whey and thin stillage. On the other hand, there were a decrease between actual and theoretical BMP values for mixes of synthetic primary sludge and metal cutting waste, whereas there was no difference for 
the float waste. Therefore, flavorings yeast, thing stillage, acid whey and can crushing wastes demonstrated synergistic outcomes, metal cutting waste demonstrated an antagonistic outcome and float waste demonstrated a neutral outcome. Similar results, synergistic, antagonistic or neutral outcomes for each waste mixed with acetate as main unlimited substrate were obtained from previous anaerobic toxicity assays, except for the acid whey. This BMP test revealed that acid whey was a synergistic waste, whereas it was neutral in the anaerobic toxicity assay. A reason for this may be that in BMP test, acid whey showed synergism with the synthetic primary sludge, whereas it showed neutral outcome because acetate was used as co-substrate in the anaerobic toxicity assay.

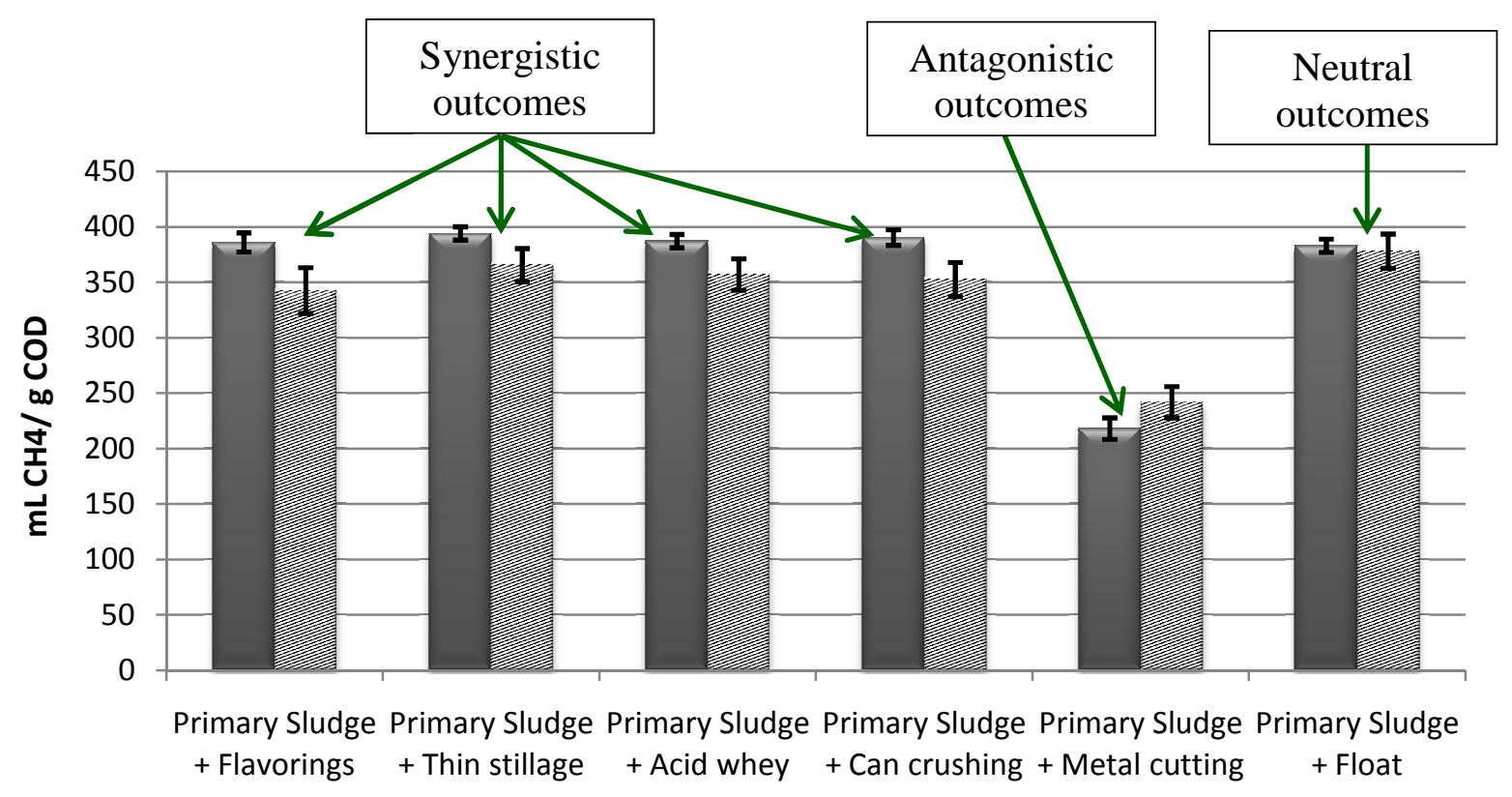

$\square$ Actual BMP of combined wastes Sum of $50 \%$ BMP of individual waste

Figure 1.20: Different co-digestion outcomes 


\subsubsection{Full-scale co-digestion testing at SSWWRF}

The characteristic of acid whey used as a co-digestate in the full-scale co-

digestion is presented in Table 1.12. Typical acid whey wastes generated in other cheese factories were reported to contain up to $70 \mathrm{~g} / \mathrm{L} \mathrm{COD}$, some carbohydrates (4-5\%) and mainly lactose (Mawson, 1994; Gelegenis et al., 2007). A similar value (60 g/L) was observed for COD of the acid whey in this study. Moreover, no alkalinity was observed in this study. Primary sludge feeding flow rate and TS and VS loading rates are presented in Table 1.13. All performance parameters of digesters were reported over 171 days of operation, including a control period of 60 days, a subsequent co-digestion period of 61 days and a post co-digestion period of 50 days. The post co-digestion period was limited to 50 days because $\mathrm{CH}_{4}$ production rate reached the value equal to the average $\mathrm{CH}_{4}$ production rate in the control period, and because another co-digestate (can crushing waste) was fed just after the post co-digestion period. Can crushing volumes were very low (2000 gallons /week) and can crushing waste testing was stopped. No data on can crushing waste digestion are reported herein.

Table 1.12: Acid whey characteristics in full-scale digestion testing

\begin{tabular}{|c|c|c|}
\hline Parameters & Value & Number of data $(n)$ used \\
\hline $\operatorname{COD}(\mathrm{g} / \mathrm{L})$ & $59.3 \pm 7.4$ & 21 \\
\hline $\mathrm{pH}$ & $3.7 \pm 0.4$ & 16 \\
\hline TS (\%) & $6.6 \pm 1.5$ & 22 \\
\hline VS/TS (\%) & $86.5 \pm 1.6$ & 22 \\
\hline $\mathrm{NH}_{3}-\mathrm{N}(\mathrm{mg} / \mathrm{L})$ & $120 \pm 20$ & 18 \\
\hline TKN (mg/L) & $650 \pm 50$ & 18 \\
\hline
\end{tabular}


Table 1.13: Primary sludge flow rate and TS and VS loading rates

\begin{tabular}{|c|c|c|c|c|c|c|c|}
\hline & & $\begin{array}{c}\text { SSPS }^{1} \\
\text { Flow to } \\
\text { digesters } \\
\text { MGD }\end{array}$ & $\begin{array}{c}\text { JIPS }^{2} \\
\text { flow to } \\
\text { digesters } \\
\text { Total } \\
\end{array}$ & TS input & VS input & $\begin{array}{c}\text { Total VS } \\
\text { feed } \\
\text { /week }\end{array}$ & $\begin{array}{c}\text { Total TS } \\
\text { feed / week }\end{array}$ \\
\hline Date & Days & MG/week & MG/week & (\%) & (\%) & $\begin{array}{c}\text { tones VS } \\
\text { /week }\end{array}$ & $\begin{array}{c}\text { tones TS } \\
\text { /week }\end{array}$ \\
\hline $4 / 27 / 2010$ & 4 & 1.22 & 1.51 & 2.42 & 1.82 & 273.59 & 363.09 \\
\hline $5 / 4 / 2010$ & 11 & 1.31 & 1.12 & 2.49 & 1.92 & 272.02 & 352.26 \\
\hline $5 / 11 / 2010$ & 18 & 1.16 & 1.52 & 2.38 & 1.82 & 265.53 & 346.73 \\
\hline $5 / 18 / 2010$ & 25 & 1.38 & 1.90 & 2.73 & 1.94 & 341.45 & 480.52 \\
\hline $5 / 25 / 2010$ & 32 & 1.34 & 0.85 & 2.84 & 2.13 & 284.87 & 381.18 \\
\hline $6 / 1 / 2010$ & 39 & 1.19 & 1.23 & 3.16 & 2.38 & 325.14 & 431.35 \\
\hline $6 / 8 / 2010$ & 46 & 1.24 & 1.04 & 2.96 & 2.21 & 295.37 & 394.27 \\
\hline $6 / 15 / 2010$ & 53 & 1.23 & 1.07 & 3.15 & 2.37 & 317.31 & 422.11 \\
\hline $6 / 22 / 2010$ & 60 & 1.21 & 1.93 & 2.77 & 1.99 & 328.92 & 457.09 \\
\hline $6 / 29 / 2010$ & 67 & 1.10 & 1.34 & 2.58 & 1.74 & 234.00 & 346.02 \\
\hline $7 / 6 / 2010$ & 74 & 1.29 & 1.25 & 2.26 & 1.65 & 238.81 & 327.56 \\
\hline $7 / 13 / 2010$ & 81 & 1.43 & 0.29 & 2.79 & 2.06 & 245.58 & 332.60 \\
\hline $7 / 20 / 2010$ & 88 & 1.30 & 1.07 & 2.64 & 1.71 & 238.00 & 367.73 \\
\hline $7 / 27 / 2010$ & 95 & 1.26 & 1.50 & 3.17 & 2.04 & 310.66 & 482.18 \\
\hline $8 / 3 / 2010$ & 102 & 1.47 & 2.19 & 3.02 & 1.95 & 379.65 & 587.36 \\
\hline $8 / 10 / 2010$ & 109 & 1.42 & 2.81 & 3.56 & 2.33 & 499.54 & 761.15 \\
\hline $8 / 17 / 2010$ & 116 & 1.85 & 0.62 & 3.38 & 2.36 & 387.73 & 554.56 \\
\hline $8 / 24 / 2010$ & 123 & 1.64 & 0.10 & 2.89 & 2.18 & 280.73 & 370.84 \\
\hline $8 / 31 / 2010$ & 130 & 1.58 & 0.13 & 2.61 & 2.04 & 253.98 & 324.22 \\
\hline $9 / 7 / 2010$ & 137 & 1.61 & 0.18 & 2.99 & 2.31 & 298.12 & 385.68 \\
\hline 9/14/2010 & 144 & 1.60 & 0.13 & 2.79 & 2.19 & 276.01 & 352.01 \\
\hline $9 / 21 / 2010$ & 151 & 1.53 & 1.35 & 2.55 & 1.91 & 318.82 & 426.07 \\
\hline $9 / 28 / 2010$ & 158 & 1.79 & 0.74 & 2.59 & 1.98 & 323.81 & 425.27 \\
\hline $10 / 5 / 2010$ & 165 & 1.82 & 1.07 & 2.60 & 2.01 & 358.07 & 463.42 \\
\hline $10 / 12 / 2010$ & 172 & 1.72 & 0.00 & 2.40 & 1.85 & 241.71 & 313.94 \\
\hline
\end{tabular}

SSPS: SSWWRF Primary sludge

${ }^{2}$ JIPS: Jones Island wastewater reclamation facility Primary Sludge 


\subsubsection{Methane production rate}

Daily biogas production and co-digestate flow rate are presented in Table A.2 of Appendix A. $\mathrm{CH}_{4}$ production rate and acid whey feed rate are presented in Figure 1.21. The average $\mathrm{CH}_{4}$ production rate during the control period was $8700 \mathrm{~m}^{3} /$ day which is presented as a horizontal line on Figure 1.21. When the co-digestate feeding was started, an increase in biogas production was expected. However, there was not a significant increase in $\mathrm{CH}_{4}$ production rate until Day 100. It may be because of a decreased VS content of the primary sludge between Days 55 and 75 (see Figure 1.23). Unfortunately, there was not precise control of TS and VS concentration of the primary sludge feed. However, average VS content of the primary sludge remained in the range of 1.6 -2.4\%. Average $\mathrm{CH}_{4}$ production per kg VS of primary sludge added during the control period was $0.21 \mathrm{~m}^{3} / \mathrm{kg} \mathrm{VS}_{\text {input }}$. This value was used to calculated theoretical $\mathrm{CH}_{4}$ production from primary sludge during the co-digestion and the post co-digestion periods. Excess $\mathrm{CH}_{4}$ gas volumes of $91,000 \mathrm{~m}^{3}$ and $124,000 \mathrm{~m}^{3}$ were estimated by calculating the difference between theoretical and actual $\mathrm{CH}_{4}$ production over co-digestion and post codigestion respectively (see Table A.3 of Appendix A). However a maximum of only $21,000 \mathrm{~m}^{3}$ could have been produced from COD of the acid whey co-digestate added based on a stoichiometric maximum of $400 \mathrm{~m}^{3} \mathrm{CH}_{4} / \mathrm{kg}$ of $\mathrm{COD}\left(35^{\circ} \mathrm{C}, 1 \mathrm{~atm}\right)$. Therefore co-digestion of the synergistic co-digestate, acid whey, increased $\mathrm{CH}_{4}$ production by an extra 194,000 $\mathrm{m}^{3}$ over the co-digestion and the post co-digestion periods. In overall the full scale co-digestion of acid whey in addition to primary sludge increased methane production by $21 \% \%$ ( $19 \%$ from synergism and $2 \%$ predicted from COD of acid whey) over co-digestion and post co-digestion periods. 


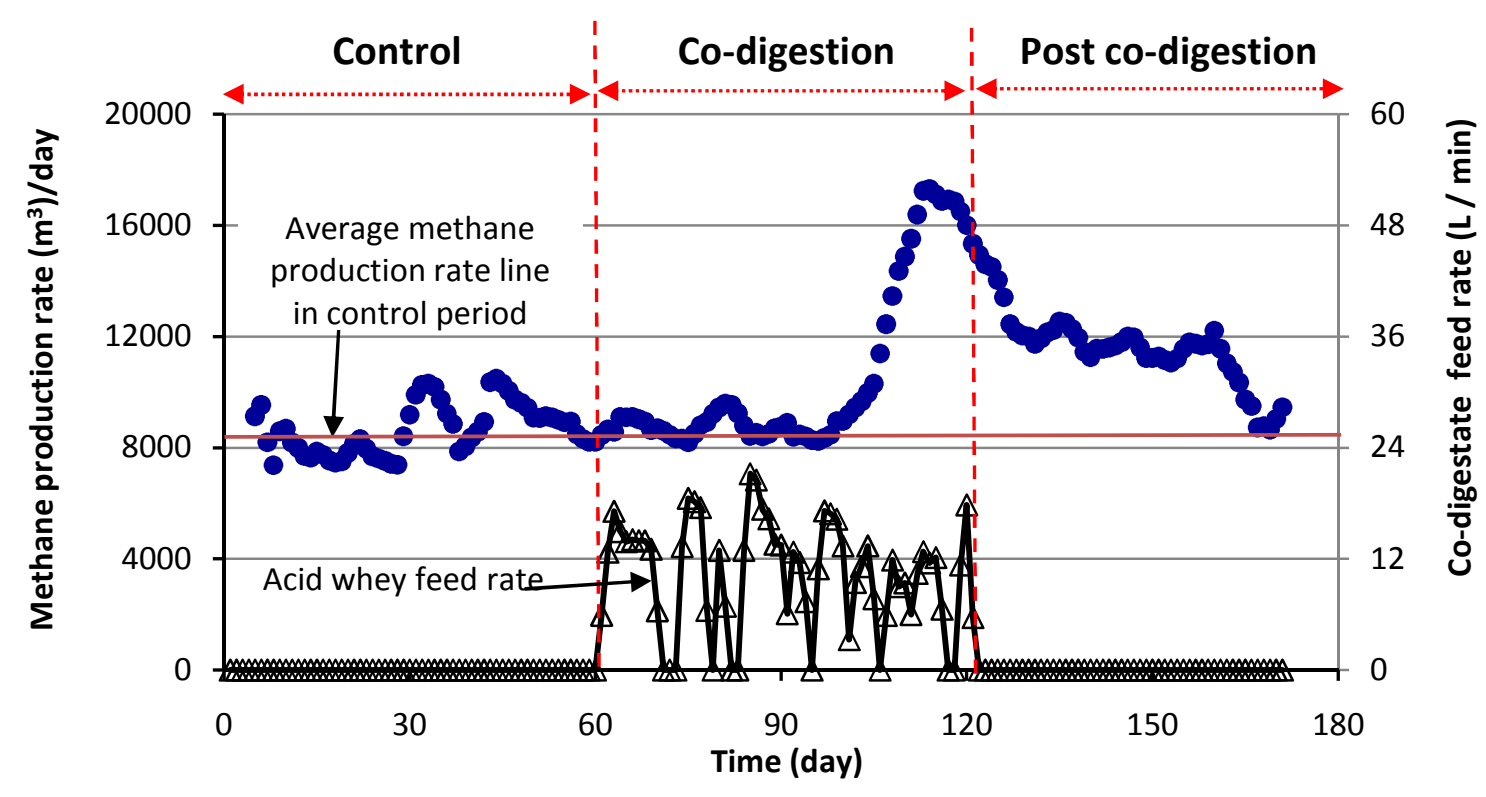

Figure 1.21: $\mathrm{CH}_{4}$ production rate and co-digestate feed rate

$\left(\mathrm{CH}_{4}\right.$ production rate: circle, 7 days running average)

\subsubsection{Percent of methane in the biogas}

Average percent of $\mathrm{CH}_{4}$ in the biogas from the five digesters is presented in

Figure 1.22. The average percent of $\mathrm{CH}_{4}$ values for the control, co-digestion and post codigestion periods were $55 \pm 3,58 \pm 2$ and $59 \pm 1$, respectively. Percent of $\mathrm{CH}_{4}$ in the codigestion and post co-digestion periods were statistically different from percent of $\mathrm{CH}_{4}$ in the control period at the $5 \%$ significance level $(\alpha<0.05)$. The percent of $\mathrm{CO}_{2}$ in the biogas was approximately 28-29\% for all periods. Co-digestion of synergistic waste increased the present of $\mathrm{CH}_{4}$ in the biogas by $5 \%$ during the co-digestion period and by $7 \%$ during the post co-digestion period as well. 


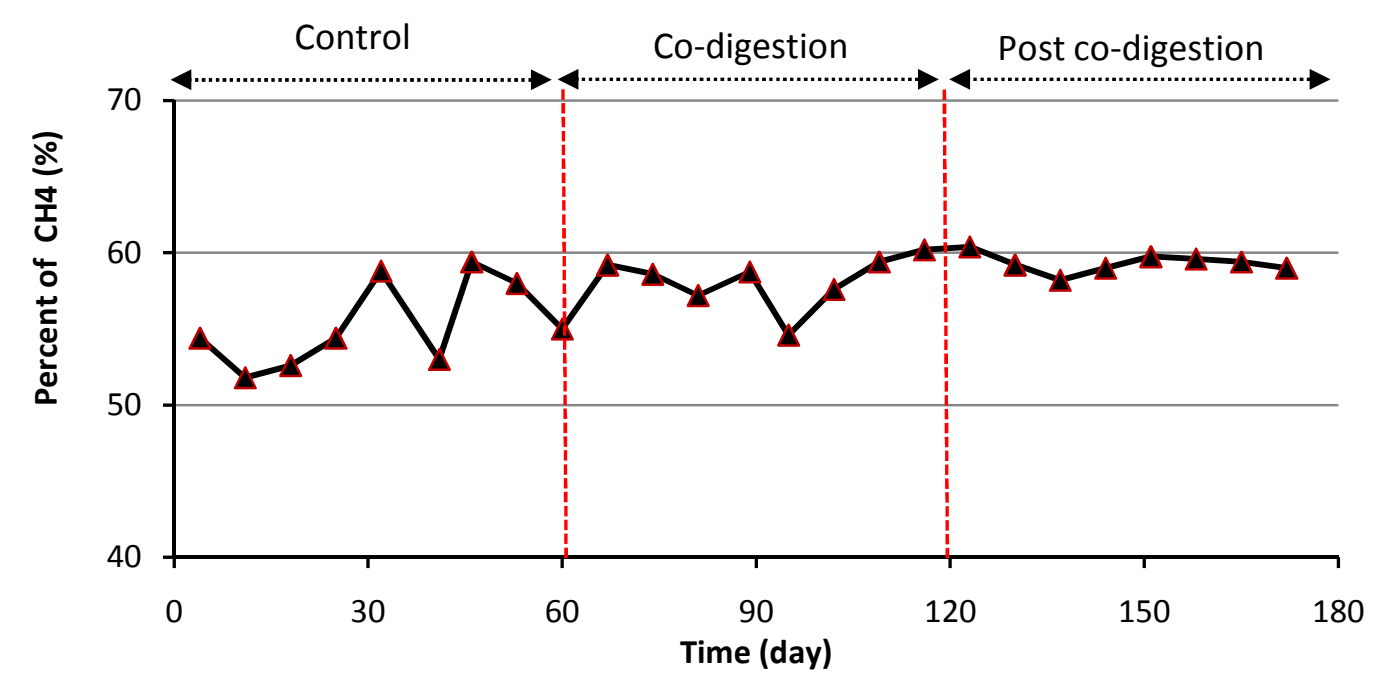

Figure 1.22: Average percent of $\mathrm{CH}_{4}$ in the digesters' biogas

\subsubsection{TS and VS removal}

The influent and effluent VS content for the digesters are presented in Figure 1.23. TS removal efficiency was $30 \%$ in the control, $33 \%$ in the co-digestion and $33 \%$ in the post co-digestion periods (see Table A.4 of Appendix A). VS removal efficiencies were $32 \%$ in the control, $34 \%$ in the co-digestion and $39 \%$ in the post co-digestion periods (see Table A.5 of Appendix A). The TS and VS reduction was 20 and $28 \%$ greater, respectively during and after co-digestion.

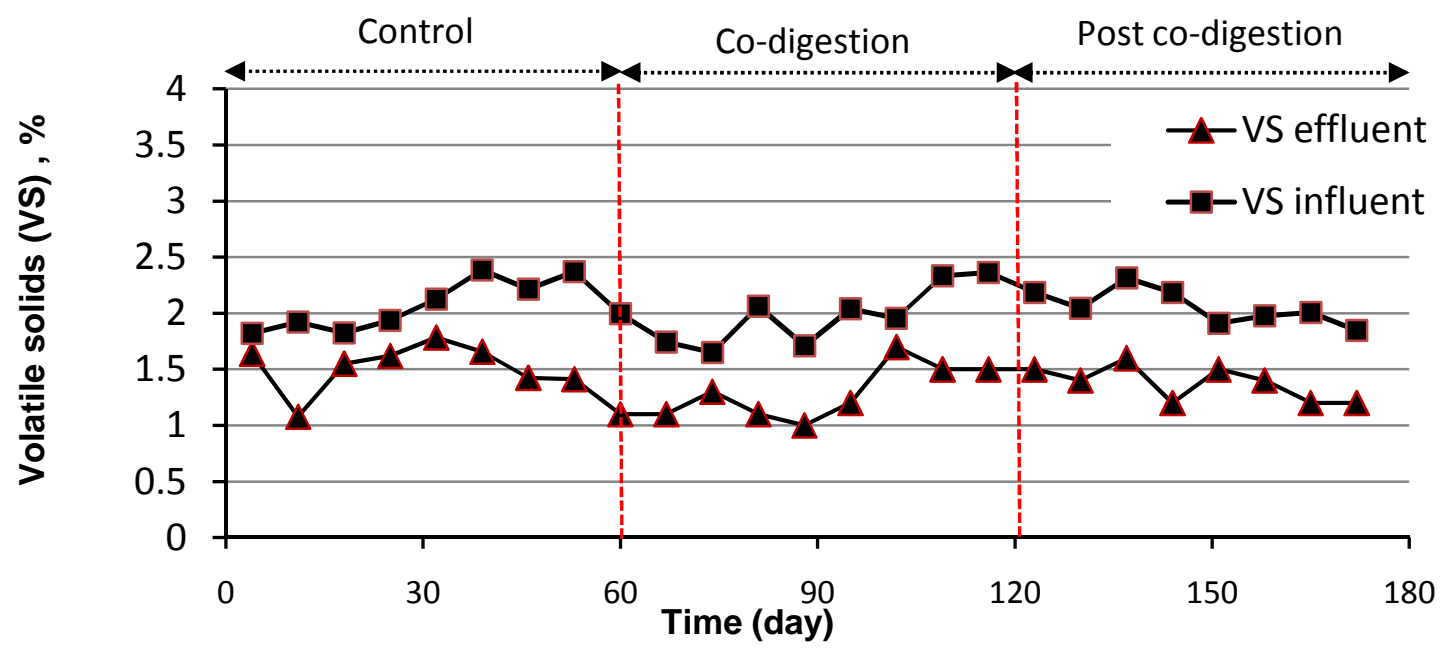

Figure 1.23: Average percent of $\mathrm{CH}_{4}$ in the digesters' biogas 


\subsubsection{4 $\mathrm{pH}$, temperature alkalinity and VFA production}

Average $\mathrm{pH}$, temperature and alkalinity of each digester are presented in Table 1.14. Values for temperature, $\mathrm{pH}$ and alkalinity were within the typical range of anaerobic digestion of municipal sludge. A stable digester has a minimum safe $\mathrm{pH}$ value of 6.8 (Speece, 2008) and a total alkalinity of 2000 to $5000 \mathrm{mg} / \mathrm{L}$ (WEF, 1996). Therefore, all digesters were operated in a stable condition.

Table 1.14: Temperature and alkalinity of digesters

\begin{tabular}{lccc}
\hline \multicolumn{1}{c}{ Digesters } & $\mathbf{p H}$ & Temperature $\left({ }^{\circ} \mathrm{C}\right)$ & $\left.\begin{array}{c}\text { Alkalinity } \\
(\mathbf{m g} / \mathrm{L} \text { as CaCO }\end{array}\right)$ \\
\hline D6 & $6.9 \pm 0.3$ & $35 \pm 5$ & $1500 \pm 200$ \\
D8 & $6.9 \pm 0.4$ & $35 \pm 7$ & $1500 \pm 200$ \\
D10 & $7.1 \pm 0.4$ & $37 \pm 2$ & $1800 \pm 500$ \\
D11 & $7.0 \pm 0.4$ & $36 \pm 2$ & $1800 \pm 200$ \\
D12 & $7.0 \pm 0.4$ & $37 \pm 1$ & $1800 \pm 200$ \\
\hline
\end{tabular}

A plot of total VFA concentration in each digester versus time is presented in Figure 1.24. Unfortunately, some VFA measurements (not shown in Figure 1.24) during the control period were more than $500 \mathrm{mg} / \mathrm{L}$. They were ostensibly sampling or analytical errors and not considered in the analysis. The total VFA concentrations of all the digesters were less the $300 \mathrm{mg} / \mathrm{L}$ during the co-digestion and post co-digestion periods. Since a typical value of VFA of a well-established anaerobic digester is less than 500 $\mathrm{mg} / \mathrm{L}$, all the digesters were under the typical limit during co-digestion and post codigestion periods. 


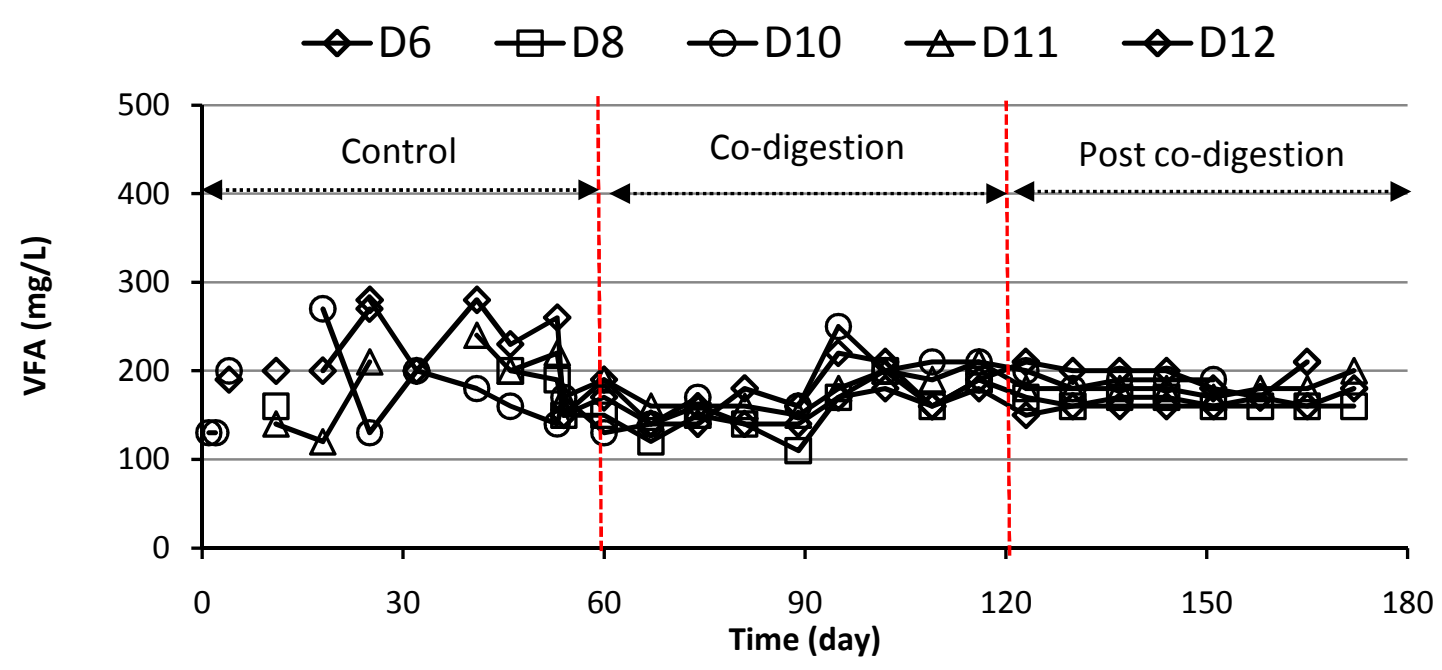

Figure 1.24: Volatile fatty acids (VFA) of each digester

\subsubsection{5 $\mathrm{NH}_{3}-\mathrm{N}$ and $\mathrm{TKN}$ of digested sludge}

The $\mathrm{NH}_{3}-\mathrm{N}$ and TKN concentrations of digested sludge during the co-digestion period were $250 \pm 40$ and $1060 \pm 270 \mathrm{mg} / \mathrm{L}$, respectively. The ratio $\mathrm{TKN} / \mathrm{NH}_{3}$ was found to be 4.2. Unfortunately, $\mathrm{NH}_{3}-\mathrm{N}$ and $\mathrm{TKN}$ concentrations of digested sludge during the control and post co-digestion periods were not measured.

\subsubsection{Mass balance}

The VS mass balance of digesters is presented in Table 1.15. VS input into the digesters, VS output from the digesters, accumulation in the digesters and ostensibly destroyed by anaerobic degradation were accounted for in the mass balance. $\mathrm{CH}_{4}$ yields from VS destroyed were estimated to be 650,704 and $676 \mathrm{~L} \mathrm{CH}_{4} / \mathrm{kg} \mathrm{VS}_{\text {destroyed }}$ in the control, co-digestion and post co-digestion periods, respectively. The $\mathrm{CH}_{4}$ yield per VS destroyed during co-digestion increased by $8 \%$ in comparison to the control. Specific $\mathrm{CH}_{4}$ yield calculated in this study was within the typical range reported by Metcalf and 
Eddy (2003) and WEF (1998). Metcalf and Eddy (2003) stated that typical $\mathrm{CH}_{4}$ yield varies from 420 to $840 \mathrm{~L} \mathrm{CH}_{4} / \mathrm{kg}$ VS destroyed for the anaerobic digestion process. WEF (1998) reported that $\mathrm{CH}_{4}$ production for various substrates as follows $\left(\mathrm{m}^{3} \mathrm{CH}_{4}\right.$ per $\mathrm{kg}$ volatile solids destroyed): fats, 0.74 to 1.15 ; scum, 0.63 to 0.75 ; grease, 0.75 ; fibers 0.36 to 0.40 ; protein 0.51 ; and typical primary sludge and activated sludge, 0.48 to 0.7 .

Table 1.15: VS mass balance of digesters

\begin{tabular}{lccc}
\hline & Control & Co-digestion & Post co-digestion \\
\hline Period considered (days) & 60 & 61 & 50 \\
Total VS added (tonne VS) & 2,560 & $2,810^{1}$ & 2,130 \\
Total VS wasted (tonne VS) & 1,860 & 1,820 & 1,430 \\
VS accumulation (tonne VS) & -120 & 50 & -140 \\
VS destroyed (Tonne VS) & 820 & 940 & 840 \\
Total $\mathrm{CH}_{4}$ produced (KCF) & 18,800 & 23,400 & 20,000 \\
Total $\mathrm{CH}_{4}$ produced (KL) & 533,000 & 663,000 & 567,000 \\
$\mathrm{~L} \mathrm{CH}_{4} / \mathrm{kg}$ VS destroyed & $\mathbf{6 5 0}$ & $\mathbf{7 0 4}$ & $\mathbf{6 7 6}$ \\
\hline
\end{tabular}

' value included 50 tonne of VS of acid whey added to the digesters

\subsection{Conclusions}

This study was performed to help develop a method/protocol to select the most promising co-digestates for full-scale co-digestion. This method included four steps: (1) preliminary screening (market survey), (2) waste characterization (BMP, ATA, sieve analysis, other tests including analyses of a suite of metals), (3) simple economic analysis, and (4) bench-scale digester testing. Co-digestion outcomes can be categorized as synergistic, neutral, antagonistic based on the biogas production rate for digestion of more than one co-digestate being greater than, the same as, or less than that observed as a sum of $\mathrm{CH}_{4}$ production rate when each waste is digested alone. 
The co-digestion of five wastes (float, spent yeast, thin stillage, acid whey and soft drink can crushing waste) in addition to primary sludge is feasible at full-scale. Codigestion of these wastes increased biogas production significantly more than the value predicted based upon their BMP values alone. Co-digestion of the most promising wastes with primary sludge in full scale was estimated to generate enough electricity (renewable energy) to power $>2500$ houses more than primary sludge digestion alone. Co-digestion in full-scale was estimated to decrease $\mathrm{CO}_{2}$ emissions. The co-digestion of most promising waste increased specific methanogenic activities (SMAs) against acetate, propionate and hydrogen as a substrate.

The full scale co-digestion of acid whey in addition to primary sludge increased $\mathrm{CH}_{4}$ production by $21 \%$ (19\% from synergism and 2\% predicted from COD of acid whey), percent of $\mathrm{CH}_{4}$ by $5 \%, \mathrm{CH}_{4}$ yield per VS destroyed by $8 \%$ (from 650 to $704 \mathrm{~L}$ $\mathrm{CH} 4$ / $\mathrm{kg} \mathrm{VS}$ destroyed $)$, total solids and volatile solids removal efficiency by $20 \%$. In conclusion, co-digestion is one method to increase renewable energy production and decrease GHG emission via anaerobic digestion. 


\subsection{References}

Ahring, B.K., Angelidaki, I., Johansen, K. (1992). Anaerobic Treatment of Manure Together with Industrial Waste. Water Sci. Technol., 25 (7), 311-318.

Alatriste-Mondragon, F., Samar, P., Cox, H.H. J., Ahring, B.K., Iranpour, R. (2006). Anaerobic Codigestion of Municpal, Farm and Industrial Organic Wastes: A Survey of Recent Literature. Water Environ. Res., 78 (6), 607-636.

Angelidaki, I., Alves, M., Bolzonella, D., Borzacconi, L., Campos, L., Guwy, A., Jenicek, P., Kalyuzhnui, S. Van Lier J. (2007). Anaerobic Biodegradation, Activity and Inhibition (ABAI) Task Group Meeting Report. Prague, Czech Republic. October 9-10.

APHA (American Public Health Association), AWWA (American Waterworks Association), and WEF (Water Environment Federation) (1998). Standard Methods for the Examination of Water and Wastewater, $20^{\text {th }}$ Edition.

Asif, M., Muneer, T. (2007). Energy Supply, Its Demand and Security Issues for Developed and Emerging Economies. Renewable and Sustainable Energy Reviews, 11 (7), 1388-1413.

Bailey, R. (2006). City of Riverside, California Grease to Gas to Power, City of Riverside California.

Bjornsson, L., Murto, M., Mattiasson, B. (2000). Evaluation of Parameters for Monitoring a Co-Digestion Process. Appl. Microbiol. Biotechnol., 54, 844-849.

Cecchi, F., Pavan, P., Mata-Alvarez, J. (1996). Anaerobic Co-Digestion of Sewage Sledge: Application to the Macroalgae from the Venice Lagoon. Resouces Conservation and Recycling, 17 (1), 57-66.

Chen, Y., Cheng, J.J., Creamer, K.S. (2008). Inhibition of Anaerobic Digestion Process: A Review. Bioresour. Technol. 99, 4044-4064.

Chung, Greg, Stephan Rank (2007). Making Cogeneration Pencil Out: Anaerobic Co Digestion of Grease Trap Waste. Proceedings of the $80^{\text {th }}$ Annual Water Environment Federation Technical Exhibition and Conference, San Diego, CA.

Coates, J.D., Cole, K, Michaelidou, U, Patrick, J, McInerney, M., Achenbach L. (2005). Biological Control of Hog Waste Odor through Stimulated Microbial Fe(III) Reduction. Appl. Environ. Microbiol., 71, 4728-4735.

Coates, J.D., Coughlan M.F., Colleran, E. (1996). Simple Method for the Measurement of the Hydrogenotrophic Methanogenic Activity of Anaerobic Sludges. Journal of Microbiological Methods, 26, 237-246. 
Cockrell Paul. (2008). Greasing Digester-Gas Production. WE\&T.

Converti, A., Drago, F., Ghiazza, G., Del Borghi, M. (1997). Codigestion of Municipal Sewage Sludge and Prehydrolyzed Woody Agricultural Waste. J. Chem. Tech. Biotechnol., 69, 231-239.

De Mes, T.Z.D., Stams, A.J.M., Reith, J.H., Zeeman, G. (2003). Methane Production by Anaerobic Digestion of Wastewater and Solid Wastes. In: Reith, J.H., Wijffels, R.H., Barten, H.(Eds.), Bio-methane \& Bio-hydrogen. Status and Perspectives of Biological Methane and Netherlands, 58-102.

Di palma, L., Medici, F., Merli, C., Petrucci, E. (1999). Anaerobic Co-Digestion of Sewage Sludge and Municipla Solid Waste from Markets: Experimental Results. Journal of Solid Waste Technology and Management, 26 (1), 10-13.

Ecke, H., Lagerkvist, A. (2000). Anaerobic Treatment of Putrescible Refuse (ATPR), Report 2000:01, The Division of Waste Science \& Technology, Lulea University of Technology, Lulea, Sweden, 47.

Edelmann, W., Engeli, H., Gradenecker, M. (2000). Codigestion of Organic Solid Waste and Sludge from Sewage Treatment. Water Sci. \& Tech., 41 (3), 213-221.

Einola, J. K., Luostarinen, S. A., Salminen, E. A., Rintala, J. A. (2001). Screening for an Optimal Combination of Municipal and Industrial Wastes and Sludges for Anaerobic Co-Digestion, Proceedings of the 9th World Congress, Anaerobic Digestion 2001, Anaerobic Conservation for Sustainability, Antwerpen, Belgium, September 2-6, 357-362.

EPA, (2011).Opportunities for and Benefits of Combined Heat and Power at Wastewater Treatment Facilities, web page http://www.epa.gov/chp/documents/wwtf_opportunities.pdf

EPA , (1999). Method 1664, Revision A: nHexane Extractable Material (HEM; Oil and Grease) and Silica Gel Treated nHexane Extractable Material (SGTHEM; Nonpolar Material) by Extraction and Gravimetry, Methods for Chemical Analysis of Water and Wastes, EPA821R98002, USEPA Office of Water, Washington, DC.

Gelegenis, J., Georgakakis, D., Angelidaki, I., Mavris, V. (2007). Optimization of Biogas Production by Co-digesting Whey with Diluted Poultry Manure. Renew. Energy, 32, 2147-2160.

Hong, B.D., Slatick, E.R. (1994). Carbon Dioxide Emissions Factors for Coal. Quarterly Coal Report, U.S. Energy Information Administration: Washington, D.C., 1-8. 
Kabouris, J.C., Tezel, U., Pavlostathis, S.G., Engelmann, M., Dulaney, J., Gillette, R.A., Todd, A.C. (2009). Mesophilic and Thermophilic Anaerobic Digestion of Municipal Sludge and Fat, Oil, and Grease. Water Environ. Res., 81, 476-485.

Kabouris, J.C., Tezel, U., Pavlostathis, S.G., Engelmann, M., Dulaney, J., Gillette, R.A., Todd, A.C. (2007). The Ultimate Anaerobic Biodegradability of Municipal Sludge and FOG. Proceedings of the $80^{\text {th }}$ Annual Water Environment Federation Technical Exhibition and Conference, San Diego, CA.

Kabouris, J.C., Tezel, U., Pavlostathis, S.G., Engelmann, M., Todd, A.C., Gillette, R.A., (2008). The Anaerobic Biodegradability of Municipal Sludge and Fat, Oil, and Grease at Mesophilic Conditions. Water Environ. Res., 80 (3), 212-221.

Karakashev, D., Batstone, D.J, Trably, E., Angelidaki, I. (2006). Acetate Oxidation Is the Dominant Methanogenic Pathway from Acetate in the Absence of Methanosaetaceae. Appl. Environ. Microbiol., 72, 5138-5141.

Kim, H.W., Han, S.K., Shin, H.S. (2004). Anaerobic Co-digestion of Sewage Sludge and Food Waste Using Temperature-Phased Anaerobic Digestion Process. Water Sci. Technol., 50 (9),107-114.

Lafitte-Trouque, S., Forster, C.F. (2000). Dual Anaerobic Codigestion of Sewage Sludge and Confectionary Waste. Bioresource Technol., 71, 77-82.

Maeng, H., Lund, H., Hvelplund, F. (1999). Biogas Plants in Denmark: Technological and Economic Developments. Applied Energy, 64, 195-206.

Mawson, A.J. (1994). Bioconversion for Whey Utilization and Waste Abatement. Biores. Technol., 47, 195-203.

McMahon, K., Zheng, D., Stams, A., Mackie, R., Raskin L. (2004). Microbial Population Dynamics during Start-Up and Overload Conditions of Anaerobic Digesters Treating Municipal Solid Waste and Sewage Sludge. Biotechnol Bioeng., 87, 823834.

Metcalf and Eddy (2003). Wastewater Engineering: Treatment and Reuse, McGraw Hill, Boston, MA.

Misi, S.N., Forster, C.F. (2002). Batch Co-Digestion of Multi-Component Agro-Wastes. Bioresource Technology, 23, 445-451.

Owen, W.F., Stuckey, D.C., Healy Jr, J.B., Young, L.Y., McCarty, P.L. (1979). Bioassay for Monitoring Biochemical Methane Potential and Anaerobic Toxicity. Water Res., 13, 485-492. 
Rizk, M.C., Bergamasco, R., Tavares, C.R.G. (2007). Anaerobic Co-digestion of Fruit and Vegetable Waste and Sewage Sludge. Int. J. Chem. Reactor Eng., 5, CP6U148.

Rodríguez, L., Villaseñor, J., Fernández, F.J., Buendía, I.M. (2007). Anaerobic CoDigestion of Winery Wastewater. Water Sci. Technol., 56 (2), 49-54.

Rosenwinkel, K.H., Meyer, H. (1999). Anaerobic Treatment of Slaughterhouse Residues in Municipal Digesters. Water Sci. Technol., 40 (1), 101-111.

Schater, P., Trueblood, D., Fonda, K., Lekven, C. (2007). Grease Processing for Renewable Energy, Profit, Sustainability, and Environmental Enhancement”. Proceedings of the $80^{\text {th }}$ Annual Water Environment Federation Technical Exhibition and Conference, San Diego, CA.

Schmit, K.H., Ellis,T.G. (2001). Comparison of Temperature-Phased and Two Phase Anaerobic Codigestion of Primary Sludge and Municipal Solid Waste. Water Environ. Res., 73, 314-312.

Speece, R.E. (1996). Anaerobic Biotechnology for Industrial Wastewaters, Archae Press: Nashville Tennessee.

Speece, R.E. (1998). A Survey of Municipal Anaerobic Sludge Digesters and Diagnostic Activity Assays. Water Res., 22 (3), 365-372.

Speece, R.E. (2008). Anaerobic Biotechnology and Odor/Corrosion Control for Municipalities and Industries, Archae Press: Nashville Tennessee.

Vik, Thomas (2003). Anaerobic Digester Methane to Energy: A Statewide Assessment, Wisconsin Focus on Energy, Spring Green, WI.

Water Environment Federation (1996). Operation of Wastewater Treatment Plants, $5^{\text {th }}$ ed., Manual of Practice No. 11, Vol. III, Chaps. 27-33, Water Environment Federation: Alexandria, Virginia.

Water Environment Federation (1998). Design of Municipal Wastewater Treatment Plants. Manual of Practice No. 8, Vol. III, Water Environment Federation: Alexandria, Virginia.

White, D. (2000). The Physiology and Biochemistry of Prokaryotes, 2 edn. Oxford University Press: New York.

York, Richard and Joseph, Magner. October 2009. "Good Grease”. WE\&T. WEF (2010). Design of Municipal Wastewater Treatment Plant. Manual of Practice No. 8, fifth edition. 
Zitomer, D., Adhikari, P., Heisel, Craig., Deneen, D. (2008). Municipal Anaerobic Digesters for Codigestion, Energy Recovery, and Greenhouse Gas Reductions. Water Environ. Res., 80 (3), 229-237. 


\section{Chapter 2}

\section{Anaerobic co-digestion with synergistic waste increases microbial activity and changes the microbial community}

Anaerobic co-digestion is a process in which a mixture of at least two different high- strength wastes is digested, producing more biogas as a source of renewable energy. Appropriate waste selection and optimum blending ratios can help maximize biogas production in co-digestion. The right balance of macro- and micro-nutrients, $\mathrm{pH}$, inhibitory/toxic compounds, biodegradable organic matter and dry matter in a waste mixture is important for co-digestion performance (Hartmann et al., 2003). Co-digestion with any combination of wastes can result in synergistic, antagonistic and neutral outcomes depending on waste composition (Zitomer et al., 2008). The synergistic, antagonistic and neutral outcomes of co-digestion can be defined based upon methane $\left(\mathrm{CH}_{4}\right)$ production that is greater than, less than or the same as that observed when each material is digested alone. Reasons for synergistic outcomes include improved nutrient balance, bio-availability of trace metals by complex agents in waste and others. The exact mechanism and fundamental reason for a synergistic outcome has not been clear defined. Most recent co-digestion research involves relationships between process performance and operating parameters and optimization of blending ratios. However, it is also important to study the influence of co-digestion on microbial communities. There is little research reported to understand the link between digester performance and microbial community structure in an anaerobic digester, and, to the author's knowledge, none involving co-digestion and microbial community. 
The degradation of organic compounds to carbon dioxide $\left(\mathrm{CO}_{2}\right)$ and $\mathrm{CH}_{4}$ occurs in four discrete steps (Speece 1996). Methanogenesis, the final step, produces $\mathrm{CH}_{4}$ and $\mathrm{CO}_{2}$ from either acetate or hydrogen/formate and $\mathrm{CO}_{2}$ (White 2000). Therefore, investigating the methongenic community is a potentially valuable tool to determine codigestion influence on the microbial community. Methyl coenzyme M reductase (mcrA) is the enzyme that catalyzes the final reaction in the methanogenesis pathway (Ermler et al. 1997). Therefore, the mcrA functional gene has been used to understand methanogenic community structure in various microbial samples. The community structure and diversity of methanogens should be investigated using molecular fingerprinting techniques to compare biomass samples from control (without codigestion) and co-digestion systems. Several molecular techniques can be used including denaturing and temperature gradient gel electrophoresis (DGGE and TGGE), single strand conformation polymorphism (SSCP), terminal-restriction fragment length polymorphism (tRFLP), 16S rRNA gene cloning and pyrosequencing. Among these techniques, DGGE is one of the most well established molecular tools for biodiversity assessment in microbial ecology (Head et al., 1998; Muyzer and Smalla, 1998; Boon et. al., 2002, Stamper et al., 2003; Arooj et al., 2007). Further, comparison and calculation of biodiversity indices (e.g. principle component analysis, Simpson's and Shannon-Weaver indices, cluster analysis, etc.) can be used to interpret data from DGGE images (Marzorati et al., 2008).

Recently, the blending of anaerobic co-digestates, synergism and economics has been reported (Navaneethan et al., 2011). In this study, the performance of bench-scale 
digesters for 3 systems (Control, Co-Digester 1 and Co-Digester 2) was monitored for six months. Co-Digester 1 and 2 systems were fed with six and two co-digestates, respectively, whereas Control systems were fed with synthetic primary sludge alone. Objectives of this study were to identify co-digestion effect on the microbial activities and microbial community structure.

\subsubsection{Research hypothesis}

In this study, three main hypotheses were defined as follows:

1. Co-digestion of synergetic co-digestates in addition to primary sludge increases biogas production significantly more than that predicted based upon BMP values alone

2. Co-digestion can increase specific methangenic activities against acetate, propionate and $\mathrm{H}_{2}$ as substrates

3. Co-digestion changes the microbial community structure in comparison to control digesters receiving synthetic primary sludge

\subsection{Methodology}

\subsubsection{Specific methanogenic activity}

The digester performance or "activity" of microbial cultures was determined using SMA tests of biomass samples against acetate and propionate (Angelidaki et al., 2007) as well as $\mathrm{H}_{2}$ (Coates et al. 2005; Coates et al. 1996) according to published methods . However, the few modifications made to these methods are described below. Assays were conducted in triplicate at $35^{\circ} \mathrm{C}, 150 \mathrm{rpm}$ using an incubator shaker (model $\mathrm{C} 25 \mathrm{KC}$, New Brunswick Scientific, Edison, NJ). All assays were performed under anaerobic 
conditions in 160-ml serum bottles. The VS concentration of the biomass was measured at the beginning of activity tests.

\subsubsection{SMA against acetate and propionate}

Fifteen mL (140-180 mg VS) and $25 \mathrm{~mL}$ (240-300 mgVS) of biomass were used in acetate and propionate activity tests, respectively. The final total volume of the assay was kept at $30 \mathrm{~mL}$ by adding the appropriate amount of basal media. Bottles were sparged with oxygen-free gas $\left(7: 3 \mathrm{v} / \mathrm{v} \mathrm{N}_{2}: \mathrm{CO}_{2}\right)$, closed with solid, black, butyl rubber septa and incubated. Approximately 3 days were allowed for degassing from residual $\mathrm{COD}$ in the biomass. $\mathrm{CH}_{4}$ content in the headspace was measured using gas chromatography (GC). Substrates were injected through the septum using a syringe and needle to achieve a calcium acetate concentration of $12 \mathrm{~g} / \mathrm{L}$ and a calcium propionate concentration of $3.4 \mathrm{~g} / \mathrm{L}$. The biogas volume produced was measured at ambient pressure and $35 \mathrm{C}$ every day using a 10 - or $100-\mathrm{mL}$ (depending upon gas production) glass syringe with a wetted glass barrel. The syringe content was re-injected into the serum bottle after volume measurement. Headspace $\mathrm{CH}_{4}$ content was measured by $\mathrm{GC}$ at the end of testing.

For acetate and propionate activities, maximum $\mathrm{CH}_{4}$ production rate $(\mathrm{mL}$ $\mathrm{CH}_{4} /$ day) was determined by linear regression of the initial, linear portion of a plot of cumulative $\mathrm{CH}_{4}$ production versus time. SMA values ( $\mathrm{mL} \mathrm{CH}_{4} / \mathrm{g}$ VS-day) were calculated by dividing maximum $\mathrm{CH}_{4}$ production rate values by average VS mass. 


\subsubsection{SMA against $\mathrm{H}_{2}$}

A sample of 8 to $12 \mathrm{mg}$ VS of biomass was used in hydrogenotrophic activity tests. The final total volume of the assay was kept at $30 \mathrm{~mL}$ by adding the appropriate amount of basal media. Bottles were sparged with oxygen-free gas $\left(7: 3 \mathrm{v} / \mathrm{v} \mathrm{N}_{2}: \mathrm{CO}_{2}\right)$, closed with solid, black, butyl rubber septa and incubated. Then, 3 days were allowed for degassing from residual COD in the biomass. Subsequently, $100 \mathrm{~mL}$ of an $\mathrm{H}_{2}$ and $\mathrm{CO}_{2}$ gas mixture (at a ratio of 1:4, v/v) at ambient pressure and temperature was injected through the septum using a syringe and needle; then the bottles were incubated. Bottle headspace volume was measured by inserting the needle of a glass syringe with wetted barrel at ambient pressure and at $35^{\circ} \mathrm{C}$ twice a day for 7 days. Syringe content was reinjected into the serum bottle after volume measurements.

For hydrogenotrophic activity, the volume of $\mathrm{H}_{2}: \mathrm{CO}_{2}$ gas utilized was calculated as from the decrease in the gas volumes in the assay plus the gas volume produced from endogenous control bottles at the given period of time. $\mathrm{CH}_{4}$ production was estimated as the volume of $\mathrm{H}_{2}: \mathrm{CO}_{2}$ gas utilized divided by 4 based upon the stoichiometry of $\mathrm{CH}_{4}$ production from $\mathrm{H}_{2}$ and $\mathrm{CO}_{2}\left(1 \mathrm{~mol} \mathrm{CH}_{4}\right.$ produced from every 4 mols $\mathrm{H}_{2}$ and $1 \mathrm{~mol}$ of $\left.\mathrm{CH}_{4}\right)$. Maximum $\mathrm{CH}_{4}$ production rate $\left(\mathrm{mL} \mathrm{CH}_{4} /\right.$ day) was determined by linear regression of the initial, linear portion of a plot of cumulative $\mathrm{CH}_{4}$ production versus time. SMA values ( $\mathrm{mL} \mathrm{CH}_{4} / \mathrm{g}$ VS-day) were calculated by dividing maximum $\mathrm{CH}_{4}$ production rate values by average VS mass. 


\subsubsection{Influence of co-digestion on diversity and population of digester microorganisms}

Molecular techniques used included denaturing gradient gel electrophoresis (DGGE) and quantitative polymerase chain reaction (qPCR).

\subsubsection{DNA extraction}

DNA was extracted from $0.75 \mathrm{~mL}$ of biomass obtained from each bench-scale digester just before co-digestion and 2 and 8 weeks after the beginning of co-digestion. The PowerSoil ${ }^{\mathrm{TM}}$ DNA Isolation Sample Kit (MoBio Laboratories, Inc., Carlsbad, CA) was used to extract DNA according to the manufacturer's instructions using the alternative lysis method. This alternative lysis method reduced the horizontal vortexing time of the PowerBead tubes from 10 to 1 minute and employed incubation at $70^{\circ} \mathrm{C}$ for 10 minutes. This ostensibly reduced shearing of DNA. The presence of extracted DNA was confirmed using agarose gel electrophoresis.

\subsubsection{Agarose gel electrophoresis}

A $1 \%$ agarose gel was prepared by mixing agarose with $1 \mathrm{X}$ Tris-Acetateethylenediaminetetraacetic acid (TAE) buffer. The resulting mixture was heated in a microwave until all the solid agarose was dissolved in TAE buffer. The solution was allowed to cool for 3 to 4 minutes before pouring into a gel box. Ethidium bromide $(0.8$ $\mu \mathrm{l} / \mathrm{mL}$ ) was added to the gel mixture for staining purposes. The prepared gel solution was poured into a gel box and allowed to solidify. A mixture of $2 \mathrm{uL} 6 \mathrm{X}$ blue-orange loading dye and a 10-uL DNA sample was injected into the wells (Hartwell et al., 2004). A DNA 
ladder containing $40 \mathrm{ng} / \mu \mathrm{L}$ Lambda $(\lambda)$ DNA, HindIII cut and $30 \mathrm{ng} / \mu \mathrm{L}$ phi X174 ( $\square)$ DNA, HaeIII cut was used as a marker. The DNA was electrophoresed under a 100-volt potential difference across the gel for one hour. Finally, migrated DNA on the gel was viewed and photographed under ultraviolet light using a bioimaging system (GDS-8000, UVP Inc. Upland, CA).

\subsubsection{Polymerase Chain Reaction (PCR)}

PCR was performed on the extracted DNA sample using EconoTaq® PLUS 2X Master Mix, which includes the Taq polymerase (Lucigen Corporation, Middleton, WI). Forward and reverse primers $(0.1 \mu \mathrm{M}$ of each $)$ were added to target the $m c r \mathrm{~A}$ gene. Nuclease-free $\mathrm{H}_{2} \mathrm{O}$ was used to make a $100-\mu \mathrm{L}$ reaction volume. The primers used for the first PCR and a second, nested PCR amplification to obtain GC clamp products for DGGE of the mcrA gene are described in Table 2.1

Table 2.1: Primers to be used in PCR reactions

\begin{tabular}{|c|c|l|c|}
\hline Gense & F/R & \multicolumn{1}{c|}{ Primer's Labels } & References \\
\hline \multirow{3}{*}{ mcrA } & Forward & $\begin{array}{l}\text { mcrA1f (5'-*GC-clamp- } \\
\text { GGTGGTGTMGGA } \\
\text { TTCACACARTAYGCWACAGC -3') }\end{array}$ & $\begin{array}{c}\text { Luton et al., } \\
2002\end{array}$ \\
\cline { 2 - 4 } & \multirow{2}{*}{ Reversed } & $\begin{array}{l}\text { McrA500r (5' }- \\
\text { TTCATTGCRTAGTTWGGRTAGTT - 3') }\end{array}$ & \\
\hline
\end{tabular}

PCR was completed using a thermal cycler (Bio-Rad PTC-200 DNA Engine, Hercules, California). Both first PCR and nested PCR required a three-step thermocycler programme in series including denature, anneal and extend. The first PCR program included denature step $\left(95^{\circ} \mathrm{C}\right.$ for $\left.5 \mathrm{~min}\right)$, anneal step $\left(35\right.$ cycles of $95^{\circ} \mathrm{C}$ for $1 \mathrm{~min}, 49^{\circ} \mathrm{C}$ for $1 \mathrm{~min}$ and $72^{\circ} \mathrm{C}$ for $\left.3 \mathrm{~min}\right)$ and extend step $\left(72^{\circ} \mathrm{C}\right.$ for $\left.7 \mathrm{~min}\right)$. The nested PCR 
program included denature step $\left(95^{\circ} \mathrm{C}\right.$ for $\left.5 \mathrm{~min}\right)$, anneal step $\left(40\right.$ cycles of $95^{\circ} \mathrm{C}$ for 1 $\min , 58^{\circ} \mathrm{C}$ for $1 \mathrm{~min}$ and $72^{\circ} \mathrm{C}$ for $\left.3 \mathrm{~min}\right)$ and extend step $\left(72^{\circ} \mathrm{C}\right.$ for $\left.7 \mathrm{~min}\right)$ as described by others (Tale, 2010).

\subsubsection{PCR purification}

For DGGE, samples were cleaned using the UltraClean ${ }^{\mathrm{TM}}$ PCR Clean-up ${ }^{\mathrm{TM}}$ Kit (MoBio Laboratories, Carlsbad, CA). This clean-up step was employed in an effort to remove unwanted reaction components.

\subsubsection{Denaturing Gradient Gel Electrophoresis (DGGE)}

DGGE was performed on a 1-mm-thick $8 \%$ polyacrylamide gel prepared per the manufacturer's protocol (Tale, 2010). Urea and formamide were used as denaturing reagents. Gels with a linear gradient of $40 \%$ denaturant concentration at the top of the gel and $80 \%$ at the bottom (expressed as v/v of the total gel) were used for electrophoresis. The highest and the lowest concentrations of the denaturant were $75 \mathrm{~mm}$ apart. A BioRad Universal DCode Mutation Detection System was used to produce the DGGE gels. The purified PCR product $(1.05 \mu \mathrm{g}, 35 \mu \mathrm{L})$ was added to each lane of the polyacrylamide gel with $7 \mathrm{~mL}$ of $6 \mathrm{X}$ loading dye. An electric potential of $100 \mathrm{~V}$ was applied across the gel for 12 hours. A $1 \%$ solution of SYBR ${ }^{\circledR}$ Gold Nucleic Acid stain (Invitrogen, CA USA) dye was used for gel staining. The gel was immersed in the staining solution and rotated on a gyratory shaker table at $1 \mathrm{rpm}$ for $30 \mathrm{~min}$ before observing it under ultra violet light using a bioimaging system (GDS-8000, UVP Inc. Upland, CA). 


\subsubsection{DGGE image analysis}

The stained DGGE gel was visualized under ultraviolet light and its image was taken using a digital camera. The Lab Works software (v. 4.6.00.0) was used for detecting bands and measuring band optical density. Parameters used for band detection are presented in Table 2.2.

Table 2.2: Parameters used for bands detection

\begin{tabular}{lc}
\hline \multicolumn{1}{c}{ Parameter } & Values \\
\hline Minimum band height & 0.05 \\
Dark bands and bright background & On \\
Rows of equal molecular weight & On \\
Allowed error (\%) & 5 \\
Maximum OD level for the image & On \\
Number of largest bands retained & 5 \\
Center peak & On \\
\hline
\end{tabular}

A common amplified DNA (mcrA) sample was prepared by mixing the amplified DNA samples from three digesters (R1, R3 and R5). This mix was used as a ladder/marker (L) for comparing densitometric data from two gel images. The ratio between the densitometric data (optical densities) from the marker lanes of the first and the second gel images was used to normalize the densitometric data of the second gel.

\subsubsection{Cluster analysis}

Pearson's correlation coefficients were calculated between lanes containing banding patterns obtained from DGGE gels to make dendrograms showing differences among banding patterns (Griffiths et al., 2000; Zhang and Fang, 2000; Kosman and Leonard, 2005). This coefficient measures the similarity between the two lanes 
containing banding patterns. Each lane represented a specific digester biomass sample. Dissimilarities/distances between the lanes were calculated as one minus Pearson's correlation coefficient. The distance matrix was constructed using obtained dissimilarities/distances between lanes. It consisted of 6 rows and 6 columns representing each digester biomass sample. The distance matrix was used to make a dendrogram using the Phylogeny Inference Package (PHYLIP, v 3.68) selecting the unweighted pair group method with arithmetic mean (UPGMA) algorithm for clustering.

Principal component analysis (PCA) was performed on the densitometric data using the MATLAB (v.7.12(R20011a)) software package. Band intensities were used as input. A graph of the first versus the second principal component was plotted in which each biomass sample represented a data point. Some samples were clustered into groups using their first two principal components by the farthest neighbor algorithm. Equations for first and second principal components are described below:

$$
\begin{aligned}
& \text { Component } 1=\sum_{m=1}^{r} \alpha_{m} \mathrm{X}_{m} \\
& \text { Component } 2=\sum_{m=1}^{r} \beta_{m} \mathrm{X}_{m}
\end{aligned}
$$

Where

$\alpha$ and $\beta$ are first and second principal components coefficients, respectively r: total number of bands $\mathrm{m}$ : band number

$$
X_{m}=I_{m}-\frac{\sum_{i=1}^{n} I_{m, i}}{n}
$$

$\mathrm{Xm}$ : Demeaned optical band intensity of $\mathrm{m}^{\text {th }}$ band for particular reactor Im : Optical band intensity of $\mathrm{m}^{\text {th }}$ band for particular reactor $\mathrm{I}_{\mathrm{m}, \mathrm{i}}$ : Optical band intensity of $\mathrm{m}^{\text {th }}$ band and $\mathrm{i}^{\text {th }}$ reactor $\mathrm{i}=$ reactor number $\mathrm{n}$ : total number of reactors 


\subsubsection{PCR and Cloning of excised bands}

PCA was also used to identify bands of interest which had the most significant effect on the clustering. A given significant band was excised from three different lanes of the DGGE gel (the Control, Co-digester 1 and Co-digester 2 sample lanes). The excised DNA bands were immediately eluted with $100 \mu \mathrm{L}$ of water and kept at $4^{\circ} \mathrm{C}$ for 2 days to allow DNA in the gel to diffuse into water. The DNA was amplified with both forward and reversed primers, mcrAlf and McrA500r, using the protocol described in the section 2.2.2.3. However, only the first PCR step was conducted for targeting mcrA genes. These PCR products were run on an agarose gel to confirm presence of amplified DNA as described in section 2.2.2.2. The amplified products were cloned into One Shot ${ }^{\circledR}$ Mach $1^{\mathrm{TM}}-{ }_{-T}{ }^{\mathrm{R}}$ chemically competent $E$. coli cells using the TOPO TA Cloning ${ }^{\circledR}$ Kit according to the manufacturer's instructions (Invitrogen, Carlsbad, CA). The Chemically competent $E$. coli cells were inoculated to petri dishes containing S-

$\mathrm{Gal}^{\mathrm{TM}} /$ Kanamycin/LB Agar blend (Sigma-Aldrich, St. Louis, MO) and $50 \mathrm{mg} / \mathrm{mL}$ ampicillin. Twelve while/light colored colonies containing plasmids with amplified product were picked for each band and directly PCR amplified with PucF (5'-GGA ATT GTG AGC GGA TAA CA- $3^{\prime}$ ) and PucR (5’- GGC GAT TAA GTT GGG TAA CG - 3') primers. The PCR was performed using EconoTaq ${ }^{\circledR}$ PLUS 2X Master Mix, which includes the Taq polymerase (Lucigen Corporation, Middleton, WI). Forward and reverse primers $\left(0.1 \mu \mathrm{M}\right.$ of each) were added to target the $m c r \mathrm{~A}$ gene. Nuclease-free $\mathrm{H}_{2} \mathrm{O}$ was used to make a $100-\mu \mathrm{L}$ reaction volume. PCR was completed using a thermal cycler (BioRad PTC-200 DNA Engine, Hercules, California) using a thermocycler programme including denature, anneal and extend periods. The PCR program included denature step 
$\left(94^{\circ} \mathrm{C}\right.$ for $2 \mathrm{~min}$ ), anneal step $\left(30\right.$ cycles of $94^{\circ} \mathrm{C}$ for $1 \mathrm{~min}, 55^{\circ} \mathrm{C}$ for $1 \mathrm{~min}$ and $72^{\circ} \mathrm{C}$ for $1 \mathrm{~min})$ and extend step $\left(72^{\circ} \mathrm{C}\right.$ for $\left.10 \mathrm{~min}\right)$. These PCR products were run on an agarose gel to confirm presence of amplified DNA as described in section 2.2.2.2.

\subsubsection{PCR purification}

Amplified samples were cleaned using the UltraClean ${ }^{\mathrm{TM}}$ PCR Clean-up ${ }^{\mathrm{TM}} \mathrm{Kit}$ (MoBio Laboratories, Carlsbad, CA) according to manufacturer's instructions to remove unwanted reaction components.

\subsubsection{Sequencing and sequence reads analysis}

The purified and amplified products were sequenced at the DNA sequencing facility, University of Chicago Cancer Research Center using an Applied Biosystems 3730XL 96-capillary system. The forward and reversed sequencing reactions were performed using primers M13for 5' GTAAAACGACGGCCAGT 3' and M13rev 5' CACACAGGAAACAGCTAT GACCAT 3' respectively. A tailor-made computer program was used to clean raw sequences, form contigs, create fasta files, remove vectors and orient sequences. This program utilized the UniVec Database of the National Center for Biotechnology Information (NCBI) using the Basic Local Alignment Search Tools (BLAST) to remove vector sequences (Altschul et al., 1997). The complete cleaned sequences were submitted to NCBI database as query to identify similar mcrA gene sequences using the BLASTn algorithm/program. 


\subsection{Results and Discussion}

\subsubsection{Performance of bench scale-co-digestion with most promising wastes}

Bench scale performance results are adapted from Navaneethan et al. (2011), and are summarized in Table 2.3. $\mathrm{CH}_{4}$ production rates of Co-Digestion 1 and 2 systems increased by $105 \%$ and $66 \%$ in comparison to the Control systems. The extra $\mathrm{CH}_{4}$ production from the additional co-digestates was theoretically anticipated to be $57 \%$ and $23 \%$ greater for Co-Digester 1 and 2 systems, respectively. Co-digestion of promising codigestates in addition to the primary sludge resulted in an additional $\mathrm{CH}_{4}$ production of 0.5 L/day. Therefore, co-digestion resulted in synergism. Moreover, TS and VS removal in Co-Digestion 1 and 2 systems increased by 50\% and 33\%, respectively, in comparison to the control systems.

Table 2.3: Operational and steady performance characteristics after co-digestion

\begin{tabular}{lccc}
\hline \multicolumn{1}{c}{ Parameters } & Control & Co-digester 1 & Co-digester 2 \\
\hline SRT (days) & 15 & 15 & 15 \\
Organic loading rate (g VS/L-day) & 1.6 & 2.2 & 1.9 \\
Actual $\mathrm{CH}_{4}$ (L/day) & 1.3 & 2.7 & 2.2 \\
Theoretical $\mathrm{CH}_{4}$ from co-digestates ${ }^{1}$ & 0 & 0.9 & 0.4 \\
(L/day) & 1.3 & 2.2 & 1.7 \\
Theoretical total $\mathrm{CH}_{4}(\mathrm{~L} /$ day) & 0 & 0.5 & 0.5 \\
Additional $\mathrm{CH}_{4}$ from synergism & 46 & 73 & 61 \\
(L/day) & 59 & 88 & 78 \\
TS reduction $(\%)$ & 61 & 62 & 62 \\
VS reduction $(\%)$ & & & \\
Biogas $\mathrm{CH}_{4}$ content $(\%)$ & & & \\
\hline
\end{tabular}

${ }^{1}$ Theoretical $\mathrm{CH}_{4}$ from co-digestates was calculated from BMP values of respective wastes and COD added 


\subsubsection{Specific methanogenic activity (SMA) of biomass}

The SMA values of biomass from each of the six bench-scale digesters were calculated from triplicate assays. The SMAs for the duplicate digesters in each system were not statistically different. Therefore, all six SMA measurements for each system were averaged. The SMAs against each substrate (acetate, propionate and hydrogen) are described below.

\subsubsection{SMA against acetate and propionate}

The SMAs against acetate as a substrate are presented in Figure 2.1. Error bars represent the standard deviation of the six SMAs for each system. The highest SMA values were obtained for the biomass taken from the Co-Digester 1 systems, whereas CoDigester 2 biomass also demonstrated SMA values higher than the Control systems. The increases in average SMA value of the biomass due to co-digestion were $19 \pm 9 \%$ and $18 \pm 9 \%$ for Co-Digester 1 and 2 systems, respectively, compared to the Control systems. The SMAs were statistically different at the $99 \%$ significance level between Control and Co-Digester $1(\mathrm{~F}(1,10)=31$ and $\alpha<0.001)$ as well as Control and Co-Digester 2(F (1, $10)=28.9$ and $\alpha<0.001)$. 


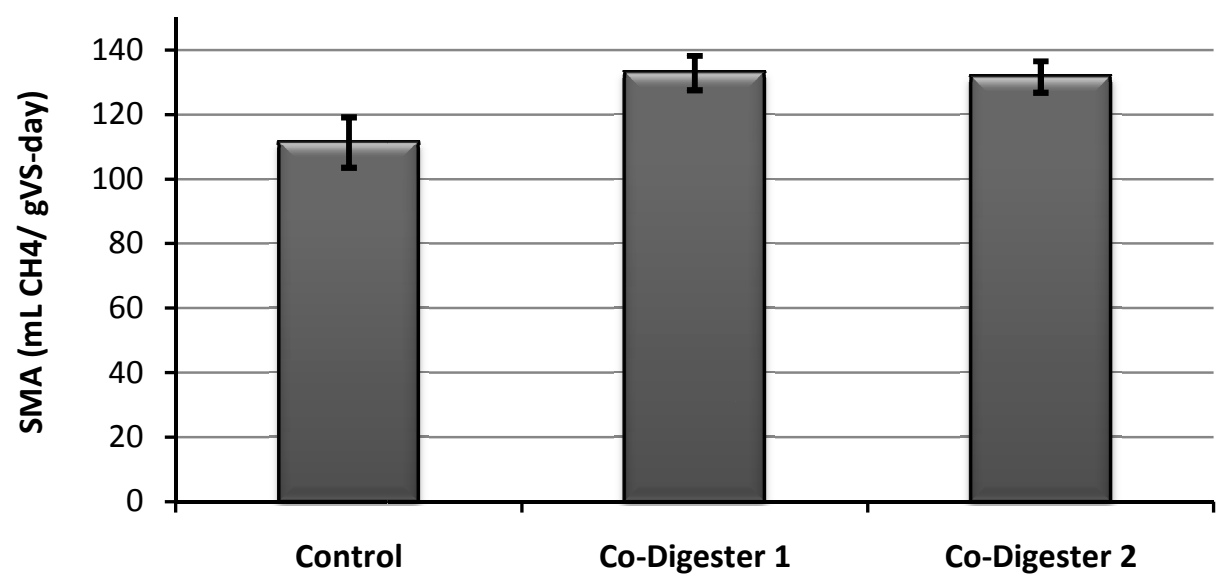

Figure 2.1: SMA results against acetate of the different conditions

The SMAs against propionate as a substrate are presented in Figure 2.2. Error bars represent the standard deviation of the six SMAs for each condition. Higher SMAs were obtained for the biomass taken from Co-Digester 1 and 2 systems. The increases in SMAs of the biomass due to co-digestion were $27 \pm 12 \%$ and $32 \pm 16 \%$ for the CoDigester 1 and 2 systems, respectively, compared to the control. The average SMA values were statistically different at the $99 \%$ significance level between Control and CoDigester $1(F(1,10)=31.8$ and $\alpha<0.001)$ as well as Control and Co-Digester $2(F(1,10)$ $=26.6$ and $\alpha<0.001)$.

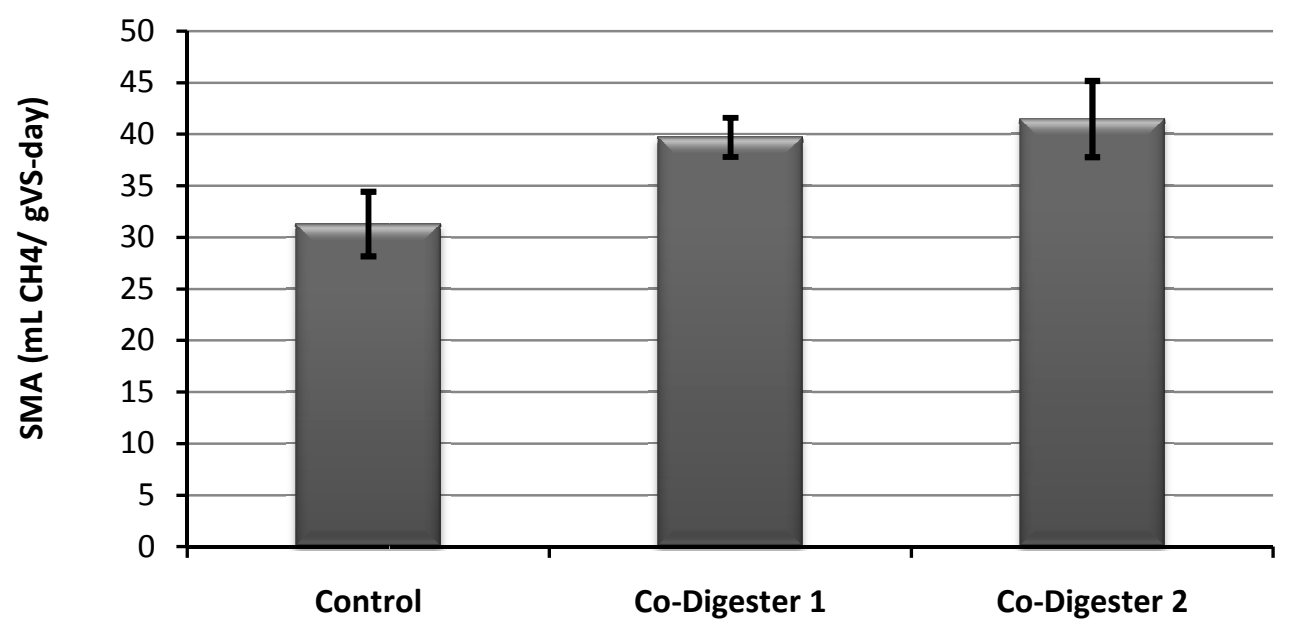

Figure 2.2: SMA results against propionate of the different conditions 


\subsubsection{SMA against $\mathrm{H}_{2}$}

The SMAs against $\mathrm{H}_{2}$ as a substrate are presented in Figure 2.3. Error bars represent standard deviation of the six SMAs for each condition. The higher SMAs were obtained for the biomass taken from the Co-Digester 1 and 2 systems. The increases in SMA values of the biomass due to co-digestion were $36 \pm 19 \%$ and $15 \pm 25 \%$ for CoDigester 1 and 2 systems, respectively, compared to the Control. The SMAs were statistically different at the 99\% significance level between Control and Co-Digester 1 systems $(F(1,10)=22.5$ and $\alpha=0.001)$, whereas the SMAs were not statistically different at the $95 \%$ significance level between the Control and Co-Digester 2 systems (F $(1,10)=2.3$ and $\alpha=0.16)$.

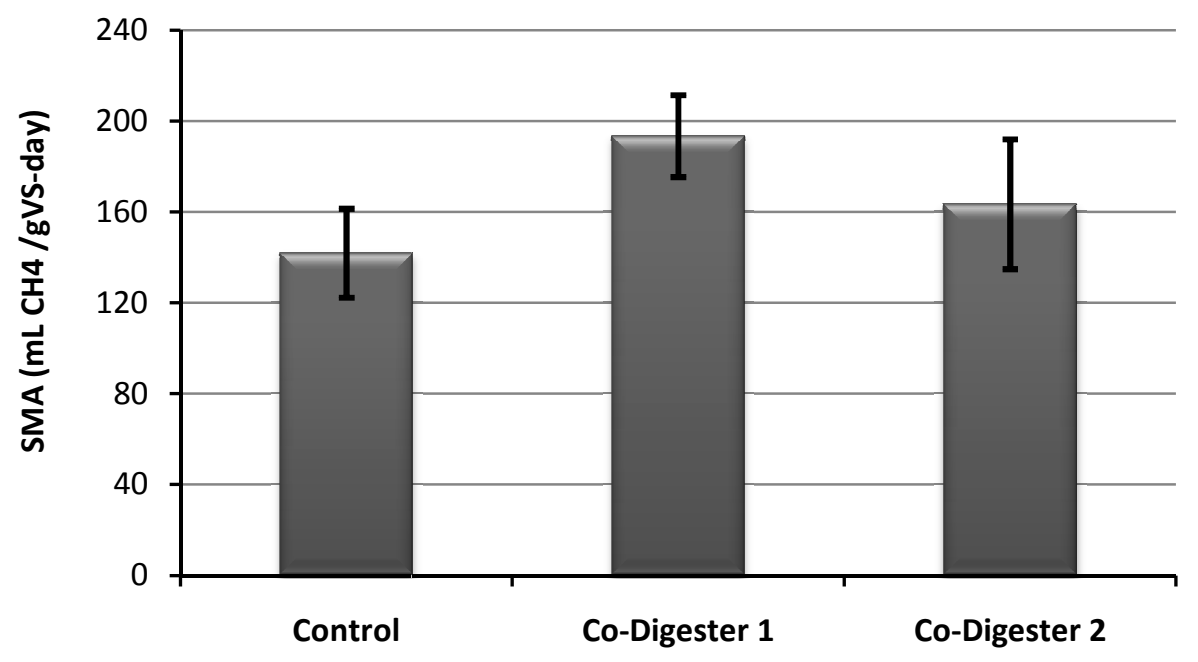

Figure 2.3: SMA results against $\mathrm{H}_{2}$ of the biomass from the different digesters

For all three substrates, acetate, propionate and $\mathrm{H}_{2}$, the SMAs of biomass in the co-digesters increased compared to that of the controls. The reasons for increased SMAs may be either an increase in the total number of microbes present in co-digesters (but the same general microbial community structure), the establishment of a new microbial 
community structure in co-digesters, or both. The microbial community structures in different digesters were compared using molecular techniques as described below.

\subsubsection{Influence of co-digestion on microbial community structure}

\subsubsection{DGGE images of mcrA}

DGGE banding patterns for the mcrA functional gene before co-digestion (a) and 8 weeks (>3 SRTs) after the start of co-digestion (b) are shown in Figure 2.4. In addition, the banding pattern 2 weeks after co-digestion is shown in Figure B.1 of Appendix B. Five major bands were detected based on the preset parameters presented in Table 2.2. Densitometric data (optical band intensities) extracted from banding patterns of DGGE images 2 and 8 weeks after the beginning of co-digestion are presented in Table B.1 of Appendix B. One band (B5) was not present before co-digestion, but appeared on all lanes (except marker lane) 2 and 8 weeks after the start of co-digestion (see Figure 2.4 and Figure B.1 of Appendix B). 


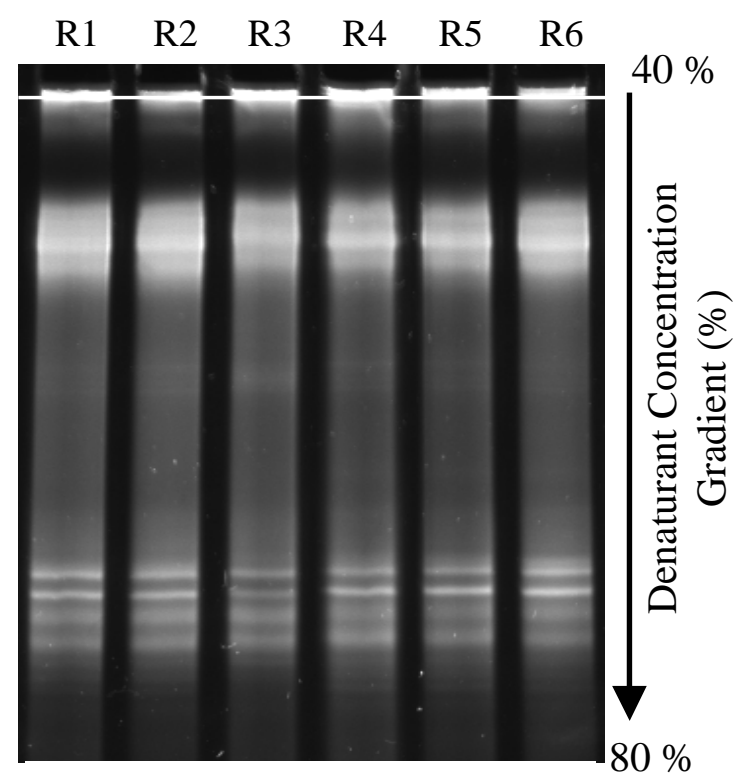

(a)

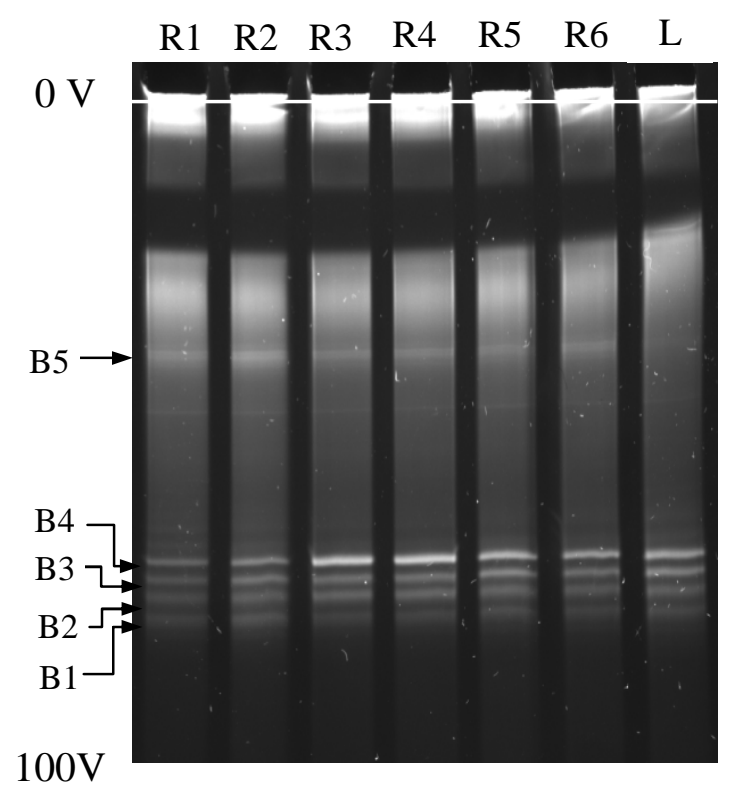

(b)

Figure 2.4: DGGE image (a) Before co-digestion and (b) at 8 weeks after codigestion

\subsubsection{Dendrogram of mcrA of biomass from digesters}

The dendrograms obtained from banding patterns of DGGE images 2 and 8 weeks

after the beginning of co-digestion are presented in Figure 2.5-2.6. The distance between each pair of samples was calculated as one minus the correlation coefficient between densitometric data (band intensities) of the two samples. The biomass samples from Reactors 1 and 2 clustered at 2 and 8 weeks after the beginning of co-digestion. This indicated that methanogenic microbial communities in the duplicate control digesters were similar. At 8 weeks (more than 3 SRTs) after co-digestion, the biomass samples from the duplicate digesters for each condition clustered together (see Figure 2.6).

Microbial communities in the Control (Reactors 1 and 2); Co-Digester 1 (Reactors 3 and 4) and Co-Digester 2 (Reactors 5 and 6) systems were different 3 SRTs after the beginning of co-digestion. 


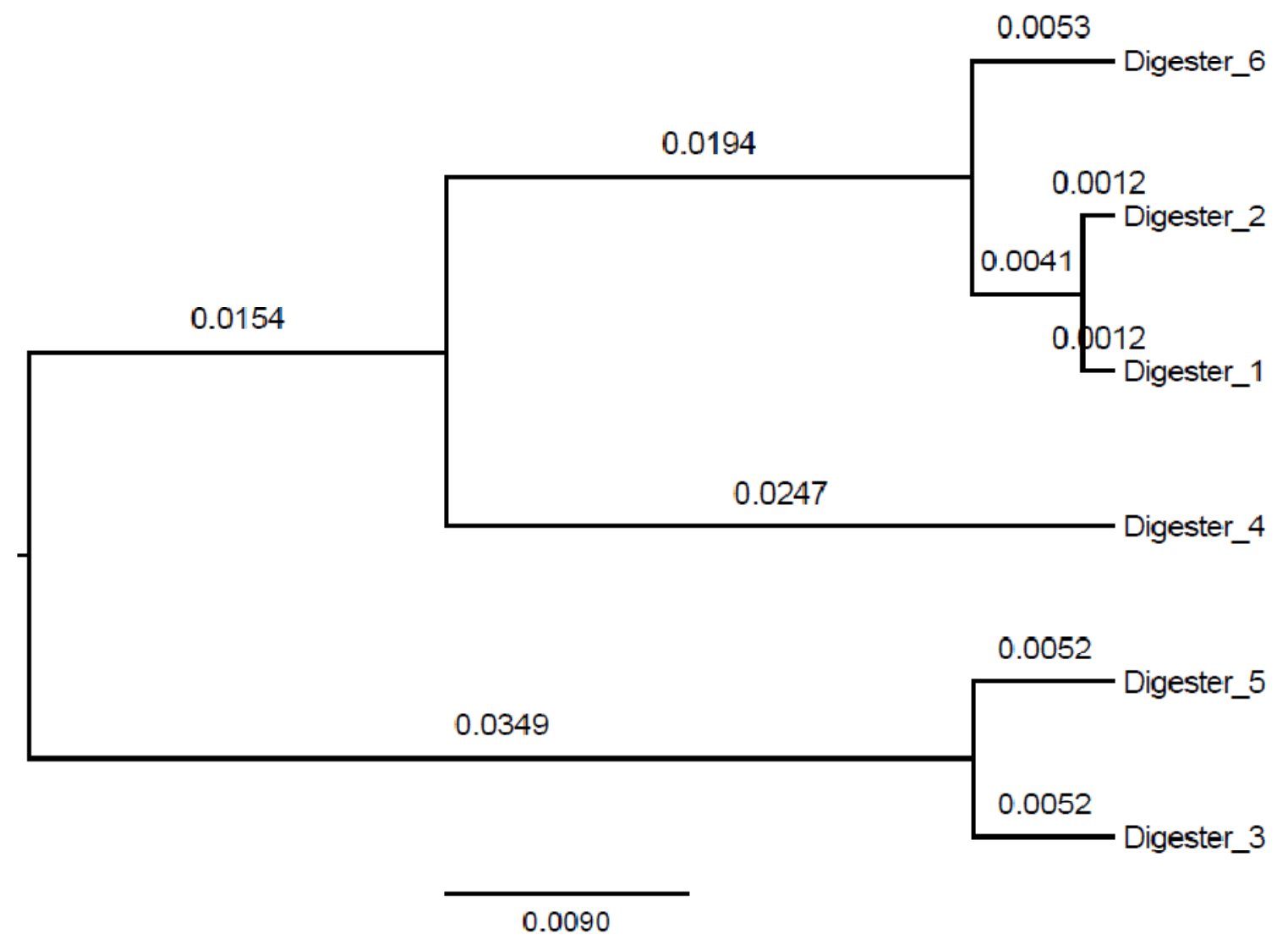

Figure 2.5: Cluster analysis of the samples at 2 weeks after co-digestion

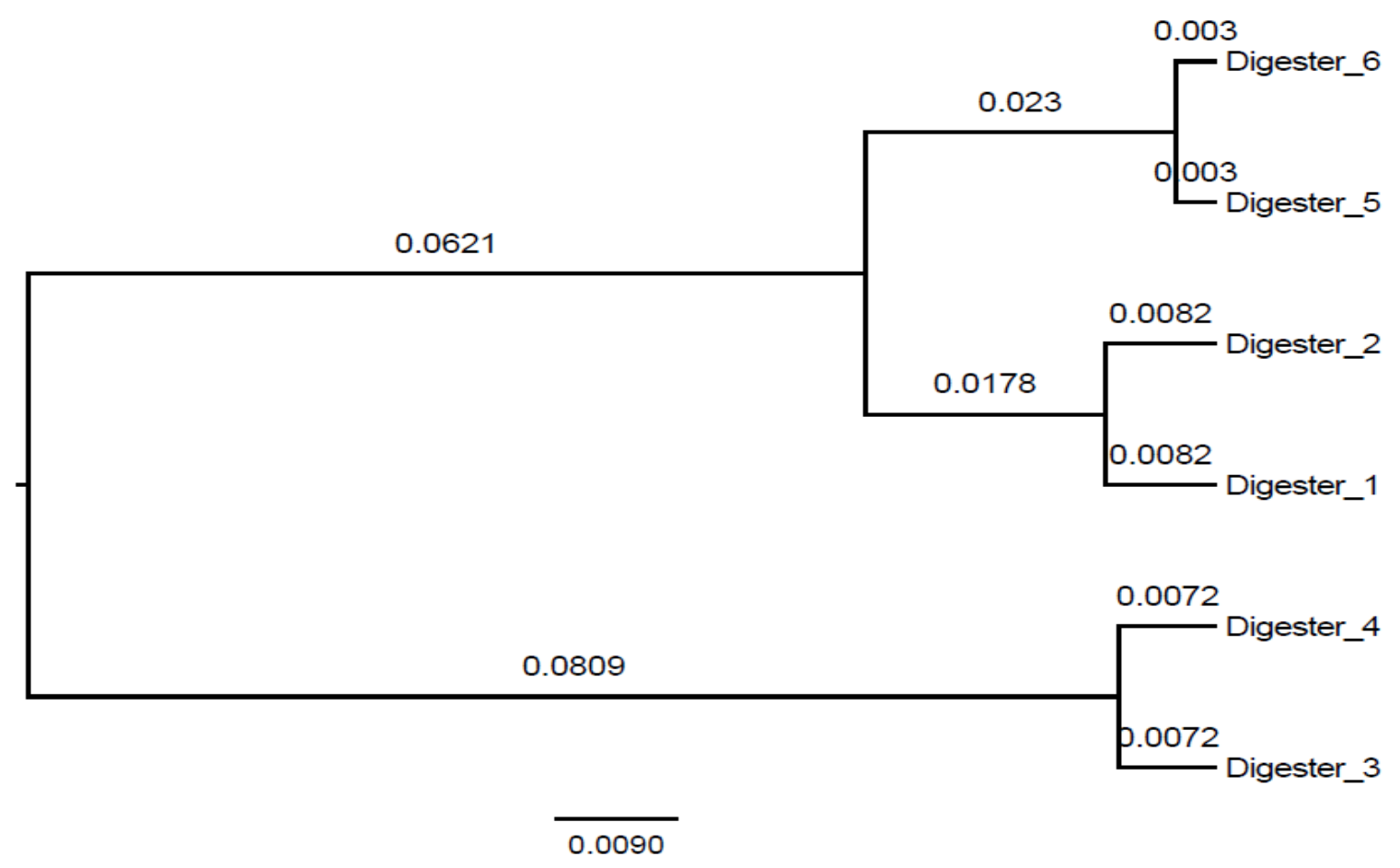

Figure 2.6: Cluster analysis of the samples at 8 weeks after co-digestion 


\subsubsection{Principal component analysis (PCA)}

The principal component analysis of densistometric data (band intensities) of each biomass sample at 2 and 8 weeks after beginning of co-digestion is presented in Figures $2.7-2.8$. Each data point in the plot represents the biomass sample of one digester. In this plot, the first and second principal components are denoted on the $\mathrm{x}$-axis and $\mathrm{y}$-axis, respectively. PCA analysis and dendogram cluster analysis resulted in similar findings.

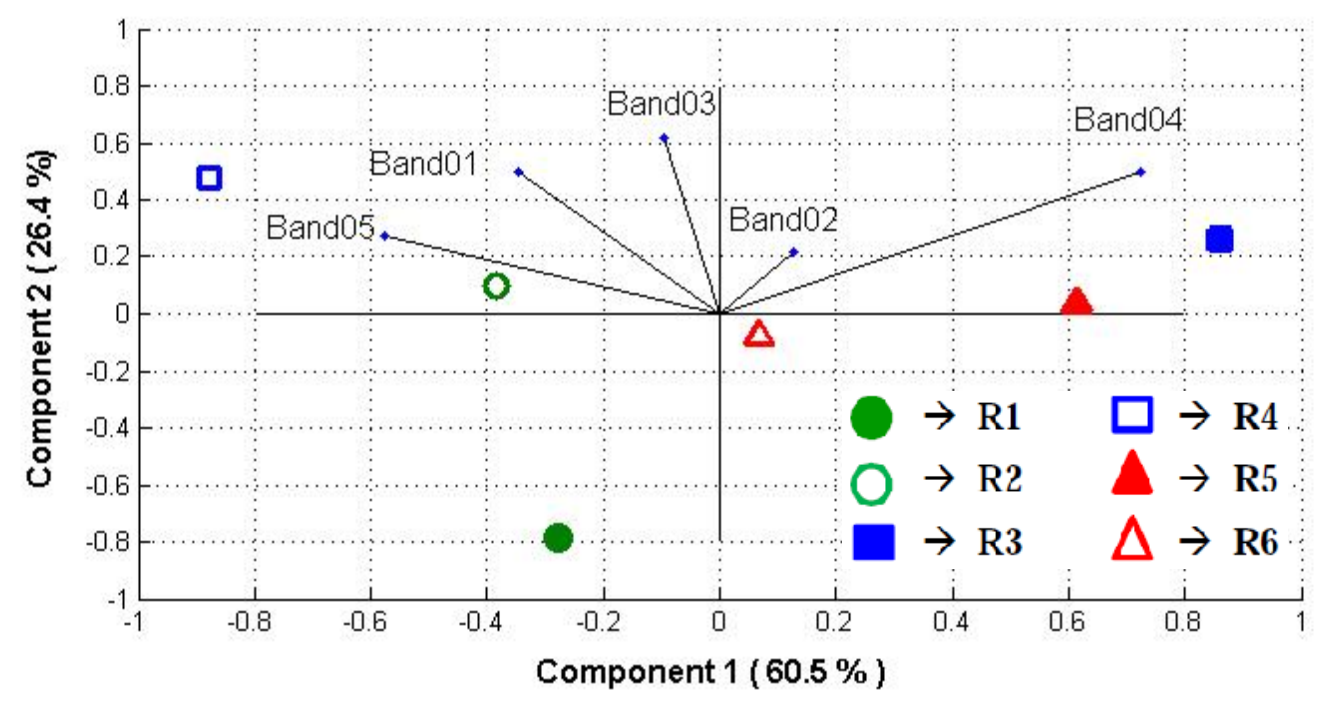

Figure 2.7: Principal component analysis results at 2 weeks after co-digestion Component $1=-0.3469\left(\mathrm{X}_{1}\right)+0.1275\left(\mathrm{X}_{2}\right)+0.0962\left(\mathrm{X}_{3}\right)+0.7222\left(\mathrm{X}_{4}\right)-0.5767\left(\mathrm{X}_{5}\right)$ Component $2=0.4985\left(\mathrm{X}_{1}\right)+2150\left(\mathrm{X}_{2}\right)+0.6169\left(\mathrm{X}_{3}\right)+0.5007\left(\mathrm{X}_{4}\right)+0.2719\left(\mathrm{X}_{5}\right)$ Where Xm : Demeaned optical band intensity of $\mathrm{m}^{\text {th }}$ band for particular reactor (see method Section 2.2.2.7) 


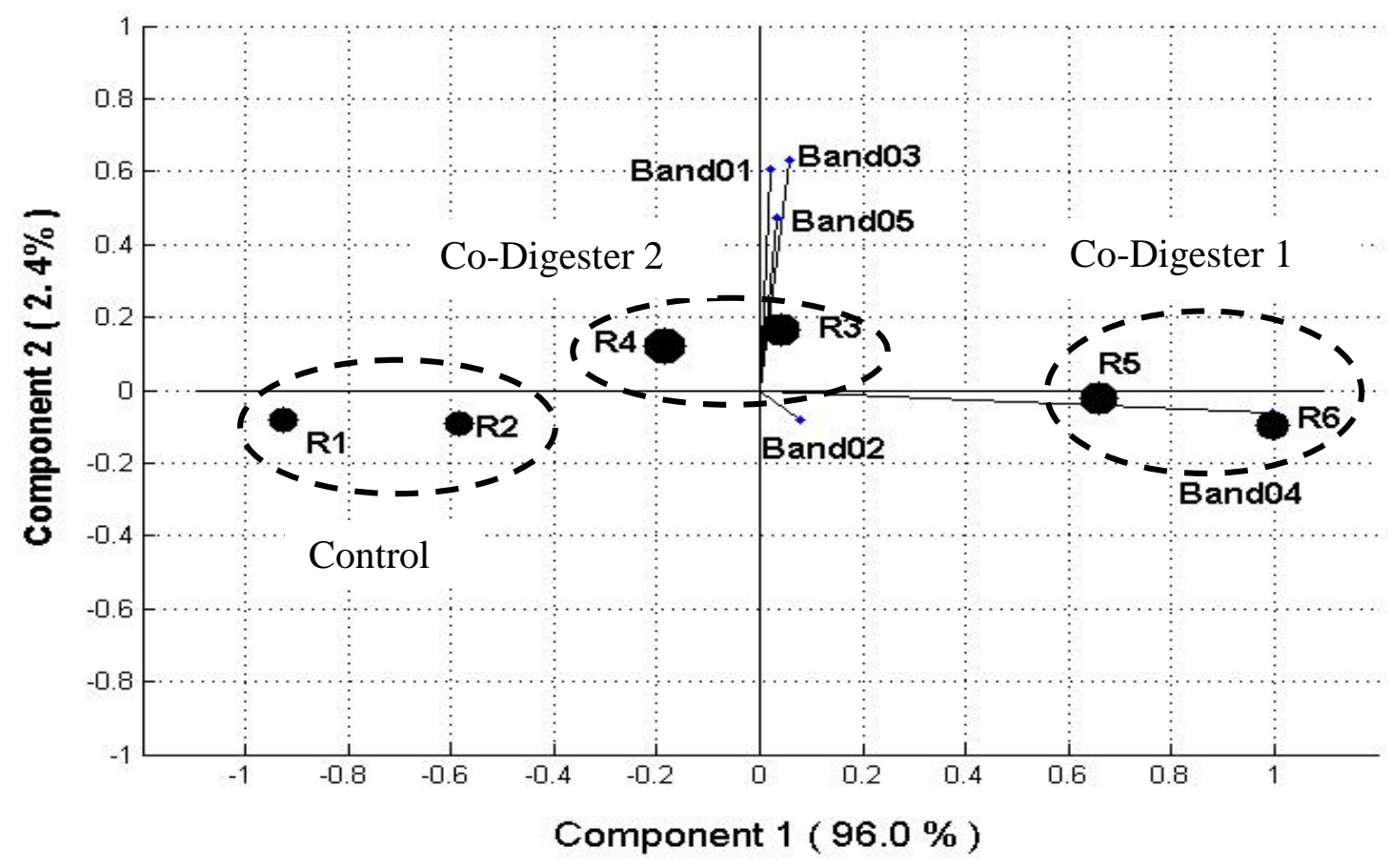

Figure 2.8: Principal component analysis results at 8 weeks after co-digestion Component $1=0.0217\left(\mathrm{X}_{1}\right)+0.0765\left(\mathrm{X}_{2}\right)+0.0595\left(\mathrm{X}_{3}\right)+0.9946\left(\mathrm{X}_{4}\right)+0.0311\left(\mathrm{X}_{5}\right)$ Component $2=0.6082\left(\mathrm{X}_{1}\right)-0.0813\left(\mathrm{X}_{2}\right)+0.6314\left(\mathrm{X}_{3}\right)-0.0595\left(\mathrm{X}_{4}\right)+0.4705\left(\mathrm{X}_{5}\right)$ Where Xm : Demeaned optical band intensity of $\mathrm{m}^{\text {th }}$ band for particular reactor (see method Section 2.2.2.7)

In the PCA at 8 weeks after the beginning of co-digestion (Figure 2.8), the first principal component explained $96 \%$ of the total variation for densitometric data. The size of the circle symbols in Figure 2.8 represents the relative values of SMA against $\mathrm{H}_{2}$, i.e.larger circles denote higher SMA values. Points (biomass) in the plot (see Figure 2.8) were clustered into 3 groups representing three different conditions, Control, Co-Digester 1 and Co-Digester 2 systems, using nearest neighbor algorithm. The three conditions were different based on methanogenic microbial community structures. The different specific methanogenic activities (SMAs) obtained among the three conditions may be explained by these changes in methanogenic microbial structure, since microbial community structure affects the rate and extent of $\mathrm{CH}_{4}$ production (Tale et al., 2011). 
Each of the five variables (B1-B5) was represented in this plot by a vector, and the direction and length of the vector indicated how each band contributed to the two principal components. Therefore, Band 4 (long length) was a major contributor for partitioning the biomass samples into three clusters. Moreover, the direction of Band 4 was toward the Co-Digester 1 cluster. The organism(s) represented by Band 4 ostensibly play a more significant role in Co-Digester 1 systems than others (Control and CoDigester 2). After Band 4, Band 2 and 3 were major contributors to the principal components (see Figure 2.8). Overall, performance of the Co-Digester 1 systems was correlated to the intensity of Band 4. This indicated that organisms represented by this band may have a significant metabolic function leading to higher SMAs in the system codigesting synergistic wastes.

Clones extracted from the most significant DGGE band (Band 4) shared a 90-99\% sequence similarity to Methanospirillum hungatei. Steinbery and Regan (2008) suggested that gene sequence similarities more than $88.9 \%$ and $79 \%$ could be considered to be within the genus and family levels, respectively. Therefore, the excised band was similar to Methanospirillum hungatei at the genus level. Cleaned sequences from clones were deposited in the GenBank datebase.

\subsection{4 quantitative polymerase chain reaction (qPCR)}

Microbial community structure was also investigated by Morris (2011) using qPCR with $m c r A$ specific primers and DNA as well as cDNA from Digesters 2, 3 and 5 . Quantitative polymerase chain reaction was performed on the biomass samples in tandem 
with SMA measurements. The $m c r A$ gene copy per g VSS and transcript numbers per $g$ VSS for Digester 2 (one of the Control systems), Digester 3 (one of the Co-Digester 1 systems) and Digester 5 (one of the Co-Digester 2 systems) are presented in Figures 2.9 (a) and (b), respectively. Error bars represent standard deviation of triplicate measurements. The gene copy and transcript numbers for total mcrA were not statistically different among the digesters at a confindence level of $95 \%$ (see Table B.2 and Appendix B). However, gene copy and transcript numbers for specific $m c r$ A sub groups may be different or the same. Based on results from PCA analysis of DGGE banding patterns, the specific mcrA gene (Band 4) was significantly different among the three systems and a dominant contributor to differences in methanogenic community structure.

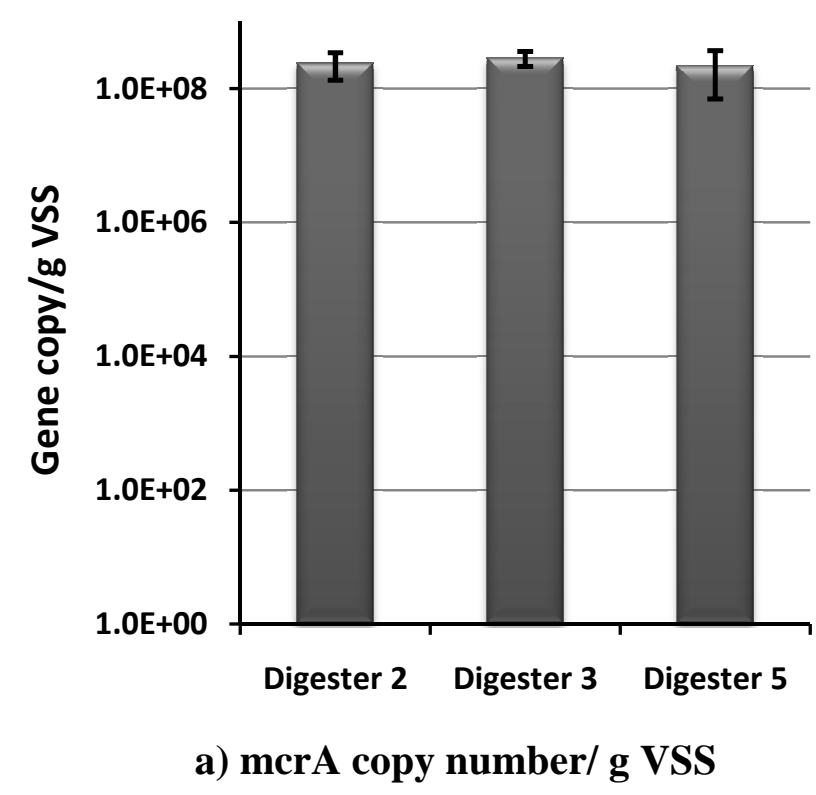

Figure 2.9: Results of qPCR for the digesters (Adapted from Morris, 2011) 


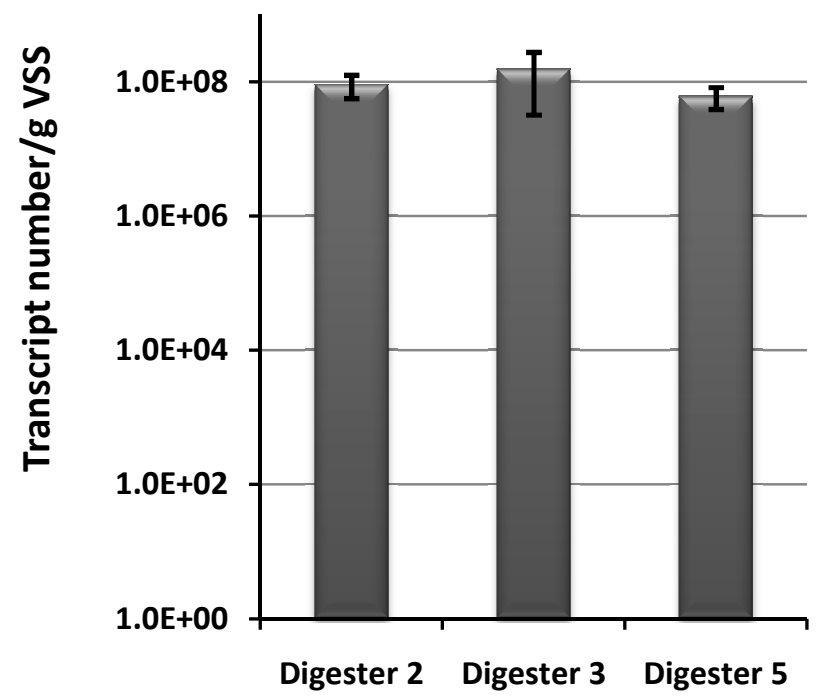

b) mcrA transcripts/ g VSS

Figure 2.9: Results of qPCR for the digesters (Adapted from Morris, 2011)

Total DNA, RNA and VSS concentrations in digesters are presented in Table 2.4. The DNA and RNA concentrations were approximately same among the digesters. The DNA and RNA concentration in the biomass did not positively correlate with volatile suspended solids concentration of the biomass.

Table 2.4: Total DNA, RNA and VSS in the digested biomass (Adapted from Morris, 2011)

\begin{tabular}{lccc}
\hline \multirow{2}{*}{ Sample Name } & \multicolumn{2}{c}{ Nucleic Acids (ng/L biomass) } & \multirow{2}{*}{$\begin{array}{c}\text { Volatile Suspended } \\
\text { Solids(g/L of biomass) }\end{array}$} \\
\cline { 2 - 3 } & DNA & RNA & 8.4 \\
\hline Digester 2 (Control) & $1.31 \times 10^{5}$ & $7.9 \times 10^{4}$ & 11.0 \\
Digester 3 (Co-Digester 1) & $1.31 \times 10^{5}$ & $8.2 \times 10^{4}$ & 8.4 \\
Digester 5 (Co-Digester 2) & $1.31 \times 10^{5}$ & $6.8 \times 10^{4}$ & \\
\hline
\end{tabular}




\subsubsection{Relationship between SMA and microbial community structures using DGGE and $q P C R$ analyses}

Both PCA and dendrogram analyses indicated that the methanogenic community in the co-digestion systems was different from that of the control. The different SMAs among the three conditions may be explained by changes in the microbial community structure. This microbial shift was a result of differences in gene copy/transcript numbers of sub groups of the mcrA gene although the total number of mcrA gene and transcrip copies was approximately the same. In addition, higher SMAs against $\mathrm{H}_{2} / \mathrm{CO}_{2}$ in the Co-

Digester 1 system may have resulted from the contribution of Methanospirillum hungatei represented by Band 4 in the $m c r$ A DGGE analysis.

\subsection{Conclusions}

Co-digestion of synergistic wastes (most promising wastes) increased $\mathrm{CH}_{4}$ production rate more that the total value of $\mathrm{CH}_{4}$ production rate when each waste was digested alone. The co-digestion of synergistic wastes (Co-Digester 1 system) increased SMAs by $19 \%, 27 \%$ and $36 \%$ against acetate, propionate and $\mathrm{H}_{2}$ as substrates, respectively. The different SMAs among three conditions were putatively due to changes in microbial community. The presence of Methanospirillum sp correlated to higher SMAs in the Co-Digester systems. Co-digestion of synergistic wastes can lead to changes in microbial community and more rapid maximum methane production rate through enhanced microbial activity. Therefore, co-digestion of synergistic wastes is one method to increase renewable energy by improving microbial community. 


\subsection{References}

Altschul, S.F., Madden, T.L., Schaffer, A.A., Zhang, J., Zhang, Z., Miller, W., and Lipman, D.J. (1997) "Gapped BLAST and PSI-BLAST: A New Generation of Protein Database Search Programs.” Nucleic Acids Res. 25: 3389-3402.

Angelidaki, I., Alves, M., Bolzonella, D., Borzacconi, L., Campos, L., Guwy, A., Jenicek, P., Kalyuzhnui, S., Van Lier J. (2007). Anaerobic Biodegradation, Activity and Inhibition (ABAI) Task Group Meeting Report. Prague, Czech Republic. October 9-10.

Arooj, M.F., Han, S.K., Kim, S.K., Kim, D.H., Shin H.S. (2007). Sludge Characteristics in Anaerobic SBR System Producing Hydrogen Gas. Water Res., 41 (6), 1177 1184.

Boon, N., Windt, W.D., Verstraete, W., Top, E.M. (2002). Evaluation of Nested PCRDGGE (Denaturing Gradient Gel Electrophoresis) With Group-Specific $16 \mathrm{~S}$ $r R N A$ Primers for the Analysis of Bacterial Communities from Different Wastewater Treatment Plants. FMES Microbiology Ecology, 39, 101-112.

Coates, J.D., Cole, K., Michaelidou, U., Patrick, J., McInerney, M., Achenbach, L. (2005). Biological Control of Hog Waste Odor through Stimulated Microbial Fe(III) Reduction. Appl. Environ. Microbiol., 71, 4728-4735.

Coates, J.D., Coughlan M.F., Colleran, E. (1996). Simple Method for the Measurement of the Hydrogenotrophic Methanogenic Activity of Anaerobic Sludges. Journal of Microbiological Methods, 26, 237-246.

Ermler, U., Grabarse, W., Shima, S., Goubeaud, M., Thauer, R. (1997). Crystal Structure of Methyl-Coenzyme M Reductase: The Key Enzyme of Biological Methane Formation. Science, 278, 1457-1462.

Griffiths, R.I., Whiteley, A.S., O’Donnell, A.G. and Bailey, M.J. (2000). Rapid Method for Coextraction of DNA and RNA from Natural Environments for Analysis of Ribosomal DNA- and rRNA- Based Microbial Community Composition. Applied and Environental Microbiology, 66 (12), 5488-5491.

Hartmann, H., Ahring, B.K. (2003). Co-digestion of the Organic Fraction of Municipal Waste With Other Waste Types. In: Mata-Alvarez, J. (Ed.), Biomethanization of the Organic Fraction of Municipal Solid Wastes. IWA Publishing, UK.

Hartwell, L.H., Hood L., Goldberg, M.L., Reynolds, A.E., Silver, L.M., Veres, R.C. (2004). Genetics: From Genes to Genomes. 2nd ed. McGraw-Hill Companies, Inc. New York, NY 
Head, I.M., Sauders, J.R. and Pickup, R.W. (1998). Microbial Evolution, Diversity, and Ecology: A Decade of Ribosomal RNA Analysis of Uncultivated Microorginisms. Microbial Ecology, 35, 1-21.

Kosman, E., Leonard, K.J. (2005). Similarity Coefficients for Molecular Markers in Studies of Genetic Relationships Between Individuals for Haploid, Diploid, and Polyploid Species. Molecular Ecology, 14, 415-424.

Luton, P.E., Wayne, J.M., Sharp, R.J., and Riley, P.W. (2002). The $m c r A$ Gene as an Alternative to $16 S$ rRNA in the Phylogenetic Analysis of Methanogen Populations in Landfill. Microbiology, 148, 3521-3530.

Marzorati, M., Wittebolle, L., Boon, N., Daffonchio, D., Verstraete, W. (2008). How to Get More Out of Molecular Fingerprints: Practical Tools for Microbial Ecology. Environ. Microbiol., 10 (6),1571-81.

Morris, R. L. (2011). Relating Methanogen Community Structure to Function in Anaerobic Wastewater Digesters, Ph.D. dissertation, Marquette University.

Muyzer, G., Smalla, K. (1998). Application of Denaturing Gradient Gel Electrophoresis (DGGE) and Temperature Gradient Gel Electrophoresis (TGGE) in Microbial Ecology. Antonie Van Leeuwenhoek, 73, 127-141.

Navaneethan, N., Topczewski, P., Royer, S., Zitomer, D. (2011). Blending Anaerobic Co-Digestates: Synergism and Economics. Water Sci. Tech., 63 (12), 2916-2922.

Speece, R.E. (1996). Anaerobic Biotechnology for Industrial Wastewaters, Archae Press: Nashville Tennessee.

Stamper, D.M., Walch, M., Jacobs, R.N. (2003). Bacterial Population Changes in A Membrane Bioreactors for Gray Water Treatment Monitored by Denaturing Gradient Gel Electrophoretic Analysis of 16S r RNA Gene Fragments. Appl. Environ. Microbiol., 69 (2), 852-860.

Tale, V.P. (2010). Bioaugmentation for Recovery of Anaerobic Digesters Subjected to Organic Overloaded, Ph.D. dissertation, Marquette University.

Tale, V.P., Maki, J.S., Struble, C.A., Zitomer, D. H. (2011). Methanogen Community Structure-Activity Relationship and Bioaugmentation of Overloaded Anaerobic Digesters. Water Res., 45 (16), 5249-5256.

White, D. (2000). The Physiology and Biochemistry of Prokaryotes, 2 ed. Oxford University Press: New York. 
Zhang, T., Fang, H.H.P. (2000). Digitization of DGGE (Denaturing Gradient Gel Electrophoresis) Profile and Cluster Analysis of Microbial Communities. Biotechnology Letters, 22 (5), 399-405.

Zitomer, D., Adhikari, P., Heisel, C., Deneen, D. (2008). Municipal Anaerobic Digesters for Codigestion, Energy Recovery, and Greenhouse Gas Reductions. Water Environ. Res., 80 (3), 229-237. 


\section{Chapter 3}

\section{Overall Conclusions, Future Study and Recommendations}

\subsection{Overall conclusions}

Co-digestion outcomes can be categorized as synergistic, neutral and antagonistic based on the biogas production for digestion of multiple wastes (more than one) being greater than, the same as, or less than that observed as a sum of methane production when each waste is digested alone. A selection of most promising and suitable wastes for fullscale is an important in order to produce addition methane production through synergism among blended wastes. A method/protocol to select the most promising waste for fullscale co-digestion included four steps: (1) preliminary screening (market survey), (2) waste characterization (BMP, ATA, sieve analysis, other test including analyses of a suite of metals), (3) simple economic analysis, and (4) bench-scale digester testing. Codigestion of synergistic wastes in full-scale increased additional biogas production significantly, which can use to produce more combined heat and power (CHP) as renewable energy and also to decrease green house gas (GHG) emission.

Co-digestion of the most promising waste increased specific methanogenic activities (SMAs) against acetate, propionate and hydrogen as a substrate. The reasons for synergistic outcomes putatuvely relate to increased methenogenic activities as a result of a methanogen community shift. The presence of Methanospirillum sp. correlated to a higher methanogenic activity of Co-Digester systems. While the total number of methanogens (mcrA gene copies) and the number of mcrA transcripts did not increase 
during co-digestion, the relative numbers and identity of the methanogen species present did change. Co-digestion of synergistic wastes can improve microbial community structure resulting in more rapid methane production rate. In conclusion, co-digestion is one method to increase renewable energy production and decrease GHG emission via anaerobic digestion.

\subsection{Future Study and Recommendations}

More research on co-digestion of industrial waste is needed to summarize findings in different categories. In addition, the number of most promising industry wastes co-digested at full scale is limited. More research is needed to identify a wider range of the most promising industrial wastes.

This study used a simple cost-benefit analysis for selecting the most promising co-digestates. The cost-benefit analysis used typical unit value/cost for $\mathrm{CH}_{4}$ produced, GHG avoided, treatment charge, waste conveyance fees and solid handling and disposal charges. Until now, there is no national standard for these unit values in the United States. Especially unit values for GHG avoided and the treatment fee may vary greatly. Therefore, more information on these values is required.

Presently, some regional municipal wastewater treatment plants employ codigestion programs. They have enough capacity to co-digest additional wastes. But they may not have sufficient equipment and storage tanks to handle different and complex 
wastes. It is important to have enough storage capacity because waste delivery to the treatment plant may be interrupted because of limitation or failure in transportation.

There is a question as to what is the highest organic loading rate sustainable for co-digestates that can be safely added to digesters. It depends on solids retention time (SRT), digester configuration and waste characteristics. Therefore, a maximum loading for each promising co-digestate should be determined and reported for most commonlyused digester configurations with different, possible SRT values. Moreover, the optimum ratio between co-digestate and municipal sludge should be determined. This research study focused on a method to identify the most promising co-digestates rather than finding the maximum loading rate and optimum ratio between primary sludge and codigestates.

In this research, synergistic outcomes of co-digestion were correlated to increased acetate, propionate and hydrogen specific methanogenic activities. However, more exact mechanisms for synergism should be identified and explained from a microbial point of view using molecular techniques like DGGE, cloning, sequencing or quantitative PCR.

In this study, the influence of co-digestion on methanogen community was investigated. However, four major groups work in the total anaerobic digestion process. It is important to understand how co-digestion influences bacteria (hydrolytic bacteria, fermenting bacteria, syntrophic acetogenic bacteria) as well as methanogens. 
Band 2 (B2) and Band (B3) on the DGGE gel was identified by PCA as the significant contributor to synergistic outcomes of Co-Digester 2 system. Therefore, the methanogens represented by B2 and B3 should be identified by sequencing the excised band.

SMAs against acetate, propionate and $\mathrm{H}_{2}$ increased for both co-digestion biomass communities compared to control biomass. This indicates that co-digestion influences either the quantity or activity of acetate, propionate and $\mathrm{H}_{2}$ utilizers. It is necessary to determine how much each group individually contributes to the synergistic outcome. This could be done using quantitative PCR (qPCR) with specific primers for acetate, propionate and $\mathrm{H}_{2}$ utilizers.

This study only focused on the influence of co-digestion on microbial communities when co-digesting synergistic wastes. It is better to compare microbial community changes/responses when co-digestesting antagonistic waste as well.

In SMA calculations, biomass presented in the sample was quantified by volatile solids (VS). It may overestimate active biomass of the sample used because VS may consist of some inert VS in addition to active biomass. 


\section{Appendix}

A 
Table A.1: Cost-benefit analysis for promising co-digestates

\begin{tabular}{|c|c|c|c|c|c|c|}
\hline & 1 & 2 & 3 & 4 & 5 & 6 \\
\hline Parameters & Cookie & Float & Whole stillage & Syrup & Trube & Brewery yeast \\
\hline $\mathrm{COD}(\mathrm{mg} / \mathrm{L})$ & 12,543 & 132,816 & 154,778 & 398,718 & 203,294 & 313,380 \\
\hline VS (\%) & 0.5 & 11.31 & 13.49 & 27.44 & 9.5 & 14.3 \\
\hline TS (\%) & 0.6 & 12.53 & 14.45 & 30.44 & 9.9 & 16.2 \\
\hline FOG $(\mathrm{mg} / \mathrm{L})$ & 3,309 & 59,400 & N/A & 51,640 & 4,580 & 280 \\
\hline BMP (mlCH4/gCODormlCH4/gVS) & 418 & 416 & 399 & 396 & 373 & 373 \\
\hline ATA & IC $50>50 \%$ & IC $50>10 \%$ & IC $50>10 \%$ & IC $50>4 \%$ & IC $50=1.8 \%$ & IC $50=4.7 \%$ \\
\hline $\mathrm{d} 50 \%$ Passing $(\mathrm{mm})$ & 0.2 & $<0.075$ & 0.39 & $<0.053$ & $<0.053$ & $<0.053$ \\
\hline Miles to South Shore WWTP & 95.2 & 15.9 & 68.6 & 68.6 & 18.15 & 18.15 \\
\hline Shipping cost $(\$ / 1000 \mathrm{gal})$ & 95.2 & 15.9 & 68.6 & 68.6 & 18.2 & 18.2 \\
\hline Soilds handling cost $(\$ / 1000 \mathrm{gal})$ & 1.5 & 28.6 & 32.1 & 69.7 & 21.5 & 37.7 \\
\hline Value of biogas $(\$ / 1000 \mathrm{gal})$ & 4.2 & 44.3 & 49.5 & 126.6 & 60.8 & 93.7 \\
\hline Treatment fee $(\$ / 1000 \mathrm{gal})$ & 13.6 & 213.4 & 247.0 & 560.6 & 223.2 & 354.5 \\
\hline Income from $\mathrm{C}$ emission credits $(\$ / 1000 \mathrm{gal})$ & 0.2 & 1.9 & 2.2 & 5.5 & 2.7 & 4.1 \\
\hline Net benefit $\left(\$ / \mathrm{m}^{3}\right)$ & -20.8 & 56.8 & 52.3 & 146.5 & 65.3 & 104.7 \\
\hline
\end{tabular}


Table A.1: Cost-benefit analysis for promising co-digestates (continued)

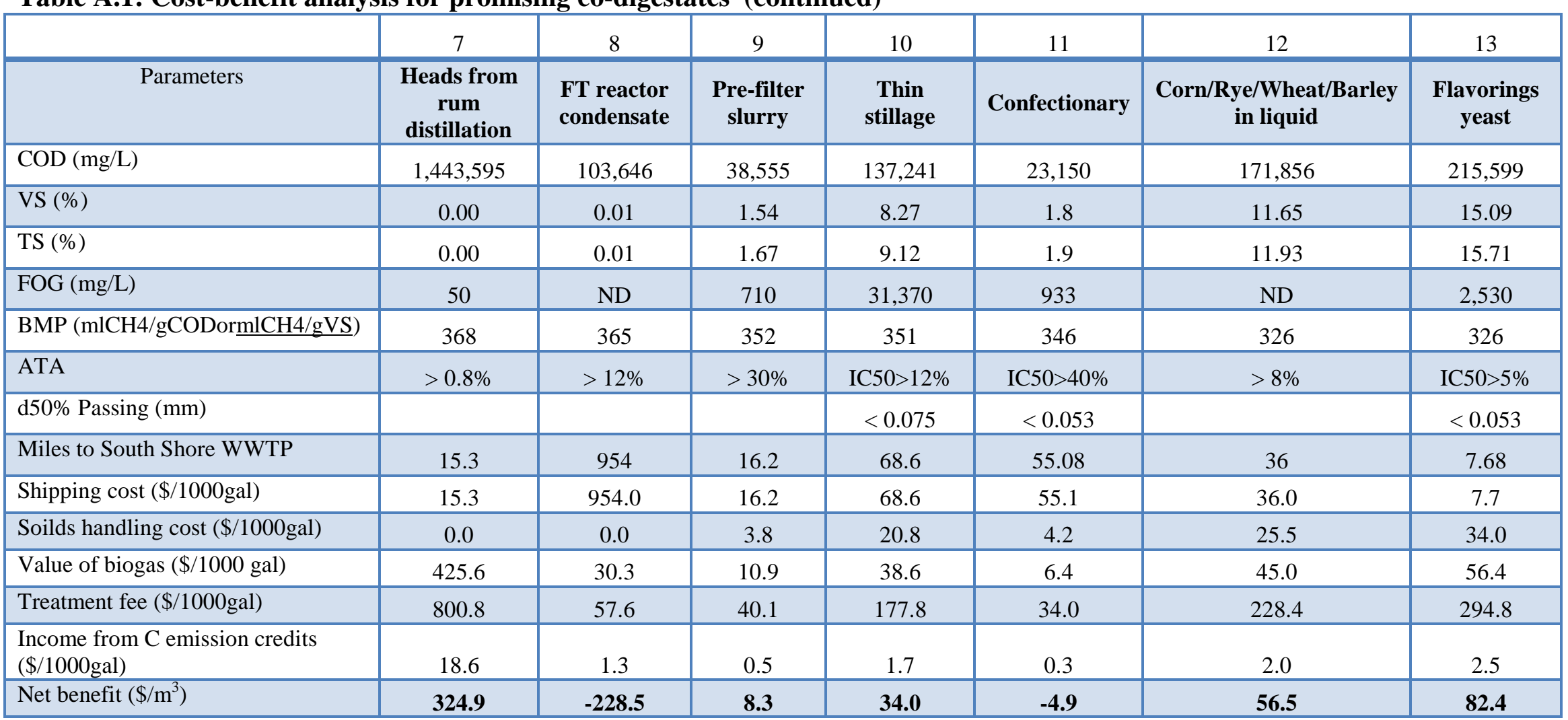


Table A.1: Cost-benefit analysis for promising co-digestates (continued)

\begin{tabular}{|c|c|c|c|c|c|c|c|}
\hline & 14 & 15 & 16 & 17 & 18 & 19 & 20 \\
\hline Parameters & $\begin{array}{l}\text { Can crushing } \\
\text { waste }\end{array}$ & Acid whey & $\begin{array}{l}\text { Yeast } \\
\text { centrate }\end{array}$ & Sorghum & $\begin{array}{c}\text { Molasses } \\
\text { wash }\end{array}$ & $\begin{array}{c}\text { Oil and } \\
\text { hydraulic } \\
\text { fluids }\end{array}$ & $\begin{array}{l}\text { Metal } \\
\text { Cutting }\end{array}$ \\
\hline VS (\%) & 5.60 & 10.75 & 0.57 & 4.78 & 6.47 & 2.37 & 2.23 \\
\hline TS (\%) & 6.10 & 12.70 & 0.59 & 5.57 & 9.33 & 2.60 & 2.29 \\
\hline ATA & IC $50>30 \%$ & IC $50>8 \%$ & IC $50>30 \%$ & $>12 \%$ & $>8 \%$ & IC $50>15 \%$ & IC $50=12.5 \%$ \\
\hline $\mathrm{d} 50 \%$ Passing $(\mathrm{mm})$ & $<0.053$ & $<0.053$ & $<0.053$ & & & $<0.053$ & $<0.053$ \\
\hline Miles to South Shore WWTP & 74.5 & 49 & 7.68 & 35 & 15.3 & 12.5 & 29.6 \\
\hline Shipping cost $(\$ / 1000 \mathrm{gal})$ & 74.5 & 49.0 & 7.7 & 35.0 & 15.3 & 12.5 & 29.6 \\
\hline Net benefit $\left(\$ / \mathrm{m}^{3}\right)$ & 11.4 & 47.8 & 6.8 & 21.8 & 42.1 & 15.4 & 9.8 \\
\hline
\end{tabular}


Table A.1: Cost-benefit analysis for promising co-digestates (continued)

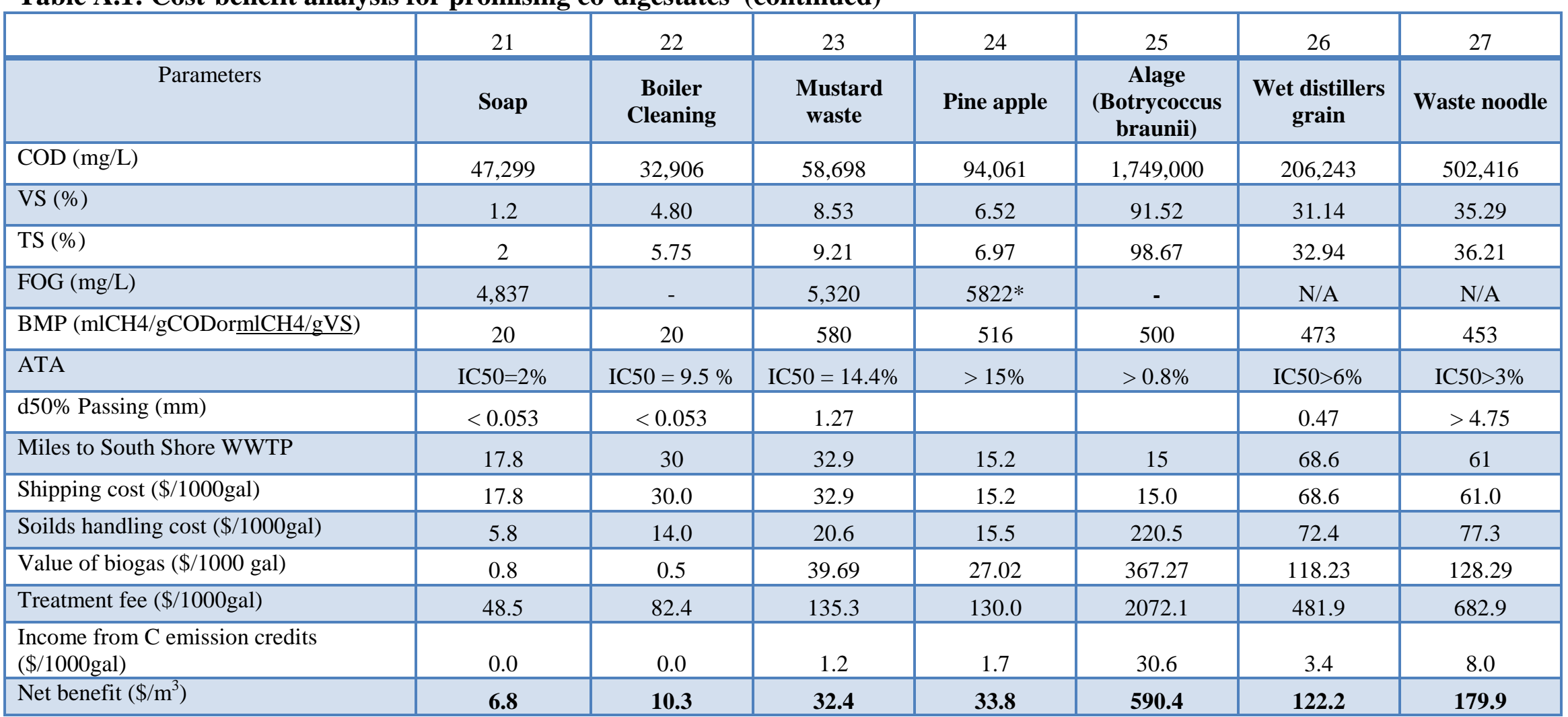


Table A.1: Cost-benefit analysis for promising co-digestates (continued)

\begin{tabular}{|c|c|c|c|c|c|c|c|}
\hline & 28 & 29 & 30 & 31 & 32 & 33 & 34 \\
\hline Parameters & Waste rice & Cabbage & Corn Stover & $\begin{array}{c}\text { Alage } \\
\text { (Nannochloropsis) }\end{array}$ & Sprout & $\begin{array}{c}\text { Brewery } \\
\text { Grain }\end{array}$ & $\begin{array}{c}\text { Cooking } \\
\text { solids }\end{array}$ \\
\hline $\mathrm{COD}(\mathrm{mg} / \mathrm{L})$ & 286,867 & 49,957 & $1,662,265$ & $1,413,000$ & 127,243 & 107,377 & $1,056,489$ \\
\hline VS (\%) & 22.69 & 4.34 & 80.76 & 87.71 & 14.33 & 20.1 & 44.63 \\
\hline $\mathrm{TS}(\%)$ & 22.98 & 4.76 & 90.30 & 96.81 & 15.00 & 21.4 & 46.76 \\
\hline FOG (mg/L) & N/A & 155 & 110 & - & N/A & N/A & 650 \\
\hline BMP (mlCH4/gCODormlCH4/gVS $)$ & 414 & 412 & 396 & 394 & 389 & 367 & 366 \\
\hline ATA & IC $50>6 \%$ & $>25 \%$ & $>0.8 \%$ & $>0.8 \%$ & IC $50>10 \%$ & IC $50>10 \%$ & $>1 \%$ \\
\hline $\mathrm{d} 50 \%$ Passing $(\mathrm{mm})$ & $>4.75$ & & & & $>0.25$ & 1.17 & \\
\hline Miles to South Shore WWTP & 61 & 15.2 & 100 & 15 & 7.68 & 18.15 & 6.2 \\
\hline Shipping cost (\$/1000gal) & 61.0 & 15.2 & 100.0 & 15.0 & 7.7 & 18.2 & 6.2 \\
\hline Soilds handling cost (\$/1000gal) & 48.5 & 10.8 & 208.0 & 220.6 & 32.6 & 47.3 & 101.9 \\
\hline Value of biogas $(\$ / 1000 \mathrm{gal})$ & 75.40 & 14.36 & 256.95 & 277.36 & 44.74 & 59.21 & 131.23 \\
\hline Treatment fee $(\$ / 1000$ gal $)$ & 415.7 & 80.9 & 1930.6 & 1864.7 & 238.0 & 298.3 & 1108.4 \\
\hline $\begin{array}{l}\text { Income from } C \text { emission credits } \\
(\$ / 1000 \text { gal })\end{array}$ & 4.2 & 0.7 & 23.0 & 19.5 & 1.7 & 1.4 & 13.5 \\
\hline Net benefit $\left(\$ / \mathrm{m}^{3}\right)$ & 101.9 & 18.5 & 502.7 & 508.8 & 64.5 & 77.5 & 302.5 \\
\hline
\end{tabular}


Table A.1: Cost-benefit analysis for promising co-digestates (continued)

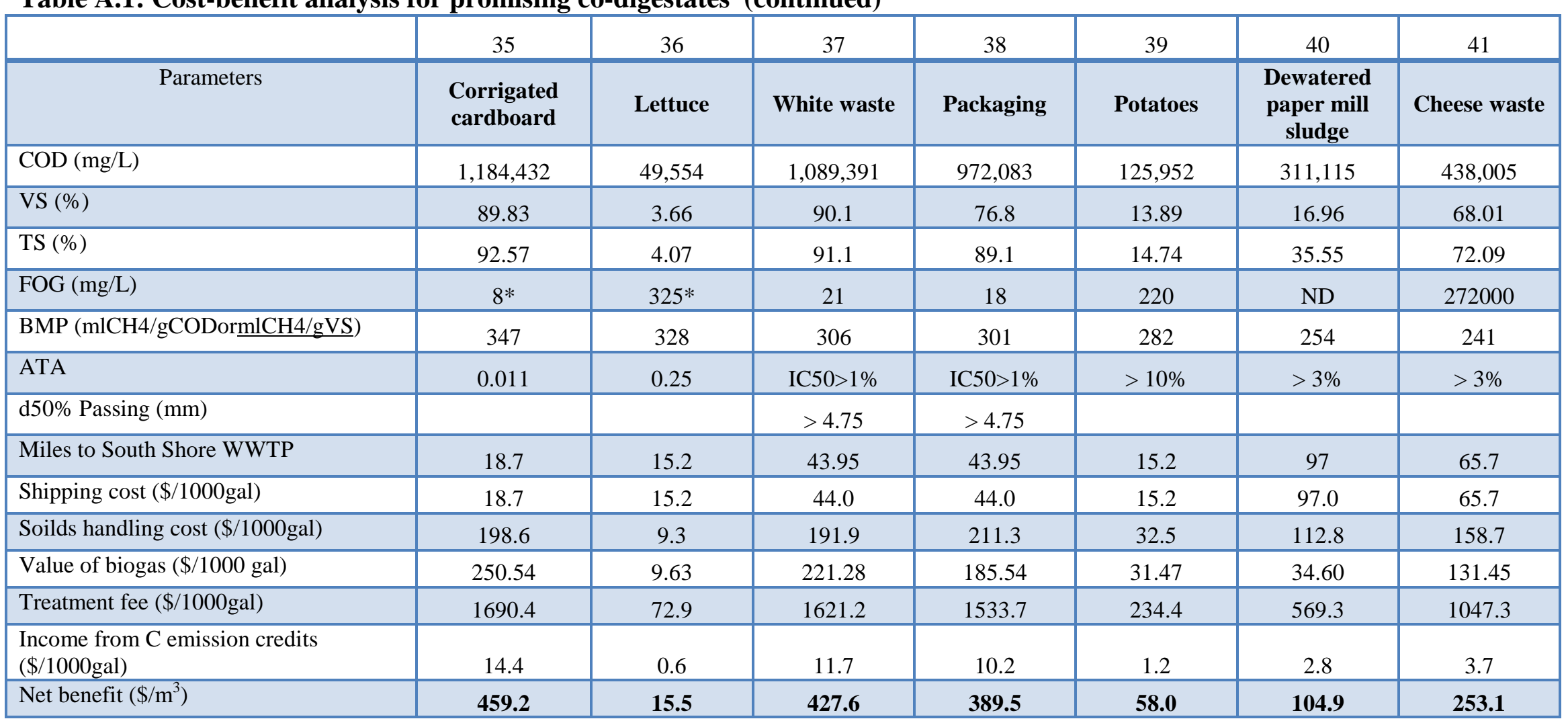


Table A.1: Cost-benefit analysis for promising co-digestates (continued)

\begin{tabular}{|c|c|c|c|c|c|}
\hline & 42 & 43 & 44 & 45 & 46 \\
\hline Parameters & Paunch & $\begin{array}{c}\text { Wood } \\
\text { chip/Charcoal }\end{array}$ & $\begin{array}{c}\text { Dried } \\
\text { manure }\end{array}$ & Cocoa husks & Composting \\
\hline $\mathrm{COD}(\mathrm{mg} / \mathrm{L})$ & 104,847 & 659,947 & 449,369 & 350,149 & 174,092 \\
\hline VS (\%) & 10.56 & 37.85 & 86.42 & 27.21 & 16.19 \\
\hline TS (\%) & 13.04 & 39.56 & 92.86 & 64.10 & 56.76 \\
\hline FOG $(\mathrm{mg} / \mathrm{L})$ & N/A & 210 & N/A & 595 & 450 \\
\hline BMP (mlCH4/gCODormlCH4/gVS $)$ & 237 & 60 & 51 & 49 & 39 \\
\hline ATA & IC $50>10 \%$ & $>1.6 \%$ & IC $50>3 \%$ & $>3 \%$ & $>6 \%$ \\
\hline $\mathrm{d} 50 \%$ Passing $(\mathrm{mm})$ & 1.1 & & 2.26 & & \\
\hline Miles to South Shore WWTP & 15.9 & 6.2 & 15.9 & 30 & 13.1 \\
\hline Shipping cost $(\$ / 1000$ gal $)$ & 15.9 & 6.2 & 15.9 & 30.0 & 13.1 \\
\hline Soilds handling cost $(\$ / 1000 \mathrm{gal})$ & 32.3 & 86.0 & 206.9 & 210.4 & 202.8 \\
\hline Value of biogas ( $\$ / 1000 \mathrm{gal})$ & 20.09 & 18.20 & 35.37 & 10.72 & 5.04 \\
\hline Treatment fee $(\$ / 1000 \mathrm{gal})$ & 203.7 & 807.8 & 1285.2 & 909.4 & 729.8 \\
\hline $\begin{array}{l}\text { Income from } C \text { emission credits } \\
(\$ / 1000 \mathrm{gal})\end{array}$ & 0.9 & 1.4 & 0.8 & 0.6 & 0.2 \\
\hline Net benefit $\left(\$ / \mathrm{m}^{3}\right)$ & 46.6 & 194.2 & 290.3 & 179.7 & 137.2 \\
\hline
\end{tabular}


Table A.2: Biogas and co-digestates flow rate for full-scale testing

\begin{tabular}{|c|c|c|c|c|c|}
\hline & & Gas Production-KCF & $\begin{array}{c}\text { Biogas } 7 \text { days } \\
\text { moving average }\end{array}$ & $\begin{array}{c}\text { Methane } 7 \text { days moving } \\
\text { average }\end{array}$ & $\begin{array}{c}\text { Co-digestate } \\
\text { flowrate }\end{array}$ \\
\hline Date & Days & KCF/day & KCF/day & m3/day & $\mathrm{L} / \mathrm{min}$ \\
\hline $4 / 28 / 2010$ & 5 & 593 & 593 & 9134 & 0.0 \\
\hline $4 / 29 / 2010$ & 6 & 619 & 619 & 9538 & 0.0 \\
\hline $4 / 30 / 2010$ & 7 & 532 & 532 & 8197 & 0.0 \\
\hline $5 / 1 / 2010$ & 8 & 503 & 503 & 7374 & 0.0 \\
\hline $5 / 2 / 2010$ & 9 & 586 & 586 & 8591 & 0.0 \\
\hline $5 / 3 / 2010$ & 10 & 592 & 592 & 8685 & 0.0 \\
\hline $5 / 4 / 2010$ & 11 & 485 & 559 & 8193 & 0.0 \\
\hline $5 / 5 / 2010$ & 12 & 499 & 545 & 7997 & 0.0 \\
\hline $5 / 6 / 2010$ & 13 & 479 & 525 & 7703 & 0.0 \\
\hline $5 / 7 / 2010$ & 14 & 507 & 522 & 7651 & 0.0 \\
\hline $5 / 8 / 2010$ & 15 & 547 & 528 & 7863 & 0.0 \\
\hline $5 / 9 / 2010$ & 16 & 532 & 520 & 7749 & 0.0 \\
\hline $5 / 10 / 2010$ & 17 & 496 & 507 & 7545 & 0.0 \\
\hline $5 / 11 / 2010$ & 18 & 448 & 501 & 7464 & 0.0 \\
\hline $5 / 12 / 2010$ & 19 & 524 & 505 & 7518 & 0.0 \\
\hline $5 / 13 / 2010$ & 20 & 618 & 525 & 7814 & 0.0 \\
\hline $5 / 14 / 2010$ & 21 & 661 & 547 & 8141 & 0.0 \\
\hline $5 / 15 / 2010$ & 22 & 497 & 539 & 8310 & 0.0 \\
\hline $5 / 16 / 2010$ & 23 & 376 & 517 & 7966 & 0.0 \\
\hline $5 / 17 / 2010$ & 24 & 371 & 499 & 7692 & 0.0 \\
\hline $5 / 18 / 2010$ & 25 & 411 & 494 & 7611 & 0.0 \\
\hline $5 / 19 / 2010$ & 26 & 485 & 488 & 7525 & 0.0 \\
\hline $5 / 20 / 2010$ & 27 & 570 & 482 & 7420 & 0.0 \\
\hline $5 / 21 / 2010$ & 28 & 646 & 480 & 7387 & 0.0 \\
\hline $5 / 22 / 2010$ & 29 & 679 & 505 & 8416 & 0.0 \\
\hline $5 / 23 / 2010$ & 30 & 699 & 552 & 9185 & 0.0 \\
\hline $5 / 24 / 2010$ & 31 & 675 & 595 & 9907 & 0.0 \\
\hline $5 / 25 / 2010$ & 32 & 559 & 616 & 10261 & 0.0 \\
\hline $5 / 26 / 2010$ & 33 & 504 & 619 & 10306 & 0.0 \\
\hline $5 / 27 / 2010$ & 34 & 522 & 612 & 10192 & 0.0 \\
\hline $5 / 28 / 2010$ & 35 & 453 & 585 & 9733 & 0.0 \\
\hline $5 / 29 / 2010$ & 36 & 467 & 554 & 9230 & 0.0 \\
\hline $5 / 30 / 2010$ & 37 & 542 & 532 & 8857 & 0.0 \\
\hline $5 / 31 / 2010$ & 38 & 621 & 524 & 7868 & 0.0 \\
\hline $6 / 1 / 2010$ & 39 & 645 & 537 & 8052 & 0.0 \\
\hline $6 / 2 / 2010$ & 40 & 653 & 558 & 8372 & 0.0 \\
\hline $6 / 3 / 2010$ & 41 & 620 & 572 & 8581 & 0.0 \\
\hline $6 / 4 / 2010$ & 42 & 616 & 595 & 8929 & 0.0 \\
\hline $6 / 5 / 2010$ & 43 & 614 & 616 & 10361 & 0.0 \\
\hline $6 / 6 / 2010$ & 44 & 593 & 623 & 10483 & 0.0 \\
\hline $6 / 7 / 2010$ & 45 & 550 & 613 & 10312 & 0.0 \\
\hline $6 / 8 / 2010$ & 46 & 537 & 598 & 10053 & 0.0 \\
\hline $6 / 9 / 2010$ & 47 & 522 & 579 & 9738 & 0.0 \\
\hline $6 / 10 / 2010$ & 48 & 566 & 571 & 9609 & 0.0 \\
\hline $6 / 11 / 2010$ & 49 & 546 & 561 & 9442 & 0.0 \\
\hline $6 / 12 / 2010$ & 50 & 555 & 553 & 9080 & 0.0 \\
\hline $6 / 13 / 2010$ & 51 & 591 & 552 & 9074 & 0.0 \\
\hline $6 / 14 / 2010$ & 52 & 574 & 556 & 9129 & 0.0 \\
\hline $6 / 15 / 2010$ & 53 & 522 & 554 & 9094 & 0.0 \\
\hline $6 / 16 / 2010$ & 54 & 485 & 548 & 9007 & 0.0 \\
\hline $6 / 17 / 2010$ & 55 & 528 & 543 & 8917 & 0.0 \\
\hline $6 / 18 / 2010$ & 56 & 556 & 544 & 8940 & 0.0 \\
\hline $6 / 19 / 2010$ & 57 & 561 & 545 & 8490 & 0.0 \\
\hline $6 / 20 / 2010$ & 58 & 513 & 534 & 8317 & 0.0 \\
\hline $6 / 21 / 2010$ & 59 & 527 & 527 & 8213 & 0.0 \\
\hline $6 / 22 / 2010$ & 60 & 522 & 527 & 8213 & 0.0 \\
\hline $6 / 23 / 2010$ & 61 & 597 & 543 & 8463 & 5.9 \\
\hline $6 / 24 / 2010$ & 62 & 617 & 556 & 8661 & 12.7 \\
\hline $6 / 25 / 2010$ & 63 & 515 & 550 & 8571 & 17.1 \\
\hline $6 / 26 / 2010$ & 64 & 511 & 543 & 9107 & 14.9 \\
\hline
\end{tabular}




\begin{tabular}{|c|c|c|c|c|c|}
\hline $6 / 27 / 2010$ & 65 & 509 & 543 & 9097 & 13.9 \\
\hline $6 / 28 / 2010$ & 66 & 534 & 544 & 9113 & 14.1 \\
\hline $6 / 29 / 2010$ & 67 & 487 & 539 & 9030 & 14.0 \\
\hline $6 / 30 / 2010$ & 68 & 562 & 534 & 8947 & 13.9 \\
\hline $7 / 1 / 2010$ & 69 & 490 & 516 & 8644 & 13.0 \\
\hline $7 / 2 / 2010$ & 70 & 539 & 519 & 8699 & 6.4 \\
\hline $7 / 3 / 2010$ & 71 & 512 & 519 & 8614 & 0.0 \\
\hline $7 / 4 / 2010$ & 72 & 446 & 510 & 8465 & 0.0 \\
\hline $7 / 5 / 2010$ & 73 & 478 & 502 & 8332 & 0.0 \\
\hline $7 / 6 / 2010$ & 74 & 483 & 501 & 8321 & 13.3 \\
\hline $7 / 7 / 2010$ & 75 & 511 & 494 & 8199 & 18.5 \\
\hline $7 / 8 / 2010$ & 76 & 618 & 512 & 8501 & 18.2 \\
\hline $7 / 9 / 2010$ & 77 & 669 & 531 & 8810 & 17.5 \\
\hline $7 / 10 / 2010$ & 78 & 654 & 551 & 8927 & 6.4 \\
\hline $7 / 11 / 2010$ & 79 & 572 & 569 & 9220 & 0.0 \\
\hline $7 / 12 / 2010$ & 80 & 578 & 584 & 9452 & 12.9 \\
\hline $7 / 13 / 2010$ & 81 & 544 & 592 & 9593 & 6.9 \\
\hline $7 / 14 / 2010$ & 82 & 491 & 589 & 9547 & 0.0 \\
\hline $7 / 15 / 2010$ & 83 & 486 & 571 & 9242 & 0.0 \\
\hline $7 / 16 / 2010$ & 84 & 478 & 543 & 8800 & 12.9 \\
\hline $7 / 17 / 2010$ & 85 & 496 & 521 & 8433 & 21.2 \\
\hline $7 / 18 / 2010$ & 86 & 517 & 513 & 8529 & 20.5 \\
\hline $7 / 19 / 2010$ & 87 & 528 & 506 & 8410 & 17.3 \\
\hline $7 / 20 / 2010$ & 88 & 580 & 511 & 8496 & 16.3 \\
\hline $7 / 21 / 2010$ & 89 & 576 & 523 & 8698 & 13.6 \\
\hline $7 / 22 / 2010$ & 90 & 515 & 527 & 8767 & 13.5 \\
\hline $7 / 23 / 2010$ & 91 & 531 & 535 & 8894 & 6.1 \\
\hline $7 / 24 / 2010$ & 92 & 558 & 544 & 8404 & 12.7 \\
\hline $7 / 25 / 2010$ & 93 & 550 & 548 & 8477 & 11.6 \\
\hline $7 / 26 / 2010$ & 94 & 496 & 544 & 8406 & 7.4 \\
\hline $7 / 27 / 2010$ & 95 & 521 & 535 & 8276 & 0.0 \\
\hline $7 / 28 / 2010$ & 96 & 561 & 533 & 8241 & 10.9 \\
\hline $7 / 29 / 2010$ & 97 & 568 & 541 & 8359 & 17.2 \\
\hline $7 / 30 / 2010$ & 98 & 580 & 548 & 8467 & 16.9 \\
\hline $7 / 31 / 2010$ & 99 & 566 & 549 & 8950 & 16.3 \\
\hline $8 / 1 / 2010$ & 100 & 556 & 550 & 8964 & 13.4 \\
\hline $8 / 2 / 2010$ & 101 & 597 & 564 & 9199 & 3.3 \\
\hline $8 / 3 / 2010$ & 102 & 627 & 579 & 9446 & 9.4 \\
\hline $8 / 4 / 2010$ & 103 & 660 & 593 & 9677 & 11.2 \\
\hline $8 / 5 / 2010$ & 104 & 694 & 611 & 9971 & 13.4 \\
\hline $8 / 6 / 2010$ & 105 & 722 & 632 & 10301 & 7.7 \\
\hline $8 / 7 / 2010$ & 106 & 886 & 677 & 11392 & 0.0 \\
\hline $8 / 8 / 2010$ & 107 & 996 & 740 & 12450 & 5.9 \\
\hline $8 / 9 / 2010$ & 108 & 1017 & 800 & 13460 & 11.9 \\
\hline $8 / 10 / 2010$ & 109 & 1001 & 854 & 14359 & 9.0 \\
\hline $8 / 11 / 2010$ & 110 & 876 & 885 & 14879 & 9.4 \\
\hline $8 / 12 / 2010$ & 111 & 961 & 923 & 15520 & 6.0 \\
\hline $8 / 13 / 2010$ & 112 & 1087 & 975 & 16397 & 10.4 \\
\hline $8 / 14 / 2010$ & 113 & 1146 & 1012 & 17252 & 12.8 \\
\hline $8 / 15 / 2010$ & 114 & 1018 & 1015 & 17306 & 11.6 \\
\hline $8 / 16 / 2010$ & 115 & 941 & 1004 & 17121 & 12.1 \\
\hline $8 / 17 / 2010$ & 116 & 901 & 990 & 16878 & 6.6 \\
\hline $8 / 18 / 2010$ & 117 & 902 & 994 & 16940 & 0.0 \\
\hline $8 / 19 / 2010$ & 118 & 931 & 989 & 16867 & 0.0 \\
\hline $8 / 20 / 2010$ & 119 & 938 & 968 & 16505 & 11.3 \\
\hline $8 / 21 / 2010$ & 120 & 922 & 936 & 16012 & 17.8 \\
\hline $8 / 22 / 2010$ & 121 & 744 & 897 & 15342 & 5.7 \\
\hline $8 / 23 / 2010$ & 122 & 775 & 873 & 14936 & 0.0 \\
\hline $8 / 24 / 2010$ & 123 & 765 & 854 & 14604 & 0.0 \\
\hline $8 / 25 / 2010$ & 124 & 864 & 848 & 14512 & 0.0 \\
\hline $8 / 26 / 2010$ & 125 & 737 & 821 & 14037 & 0.0 \\
\hline $8 / 27 / 2010$ & 126 & 684 & 784 & 13417 & 0.0 \\
\hline $8 / 28 / 2010$ & 127 & 628 & 742 & 12447 & 0.0 \\
\hline $8 / 29 / 2010$ & 128 & 629 & 726 & 12171 & 0.0 \\
\hline
\end{tabular}




\begin{tabular}{|c|c|c|c|c|c|}
\hline $8 / 30 / 2010$ & 129 & 723 & 719 & 12046 & 0.0 \\
\hline $8 / 31 / 2010$ & 130 & 748 & 716 & 12006 & 0.0 \\
\hline $9 / 1 / 2010$ & 131 & 752 & 700 & 11738 & 0.0 \\
\hline $9 / 2 / 2010$ & 132 & 819 & 712 & 11935 & $\overline{0.0}$ \\
\hline $9 / 3 / 2010$ & 133 & 774 & 725 & 12150 & 0.0 \\
\hline $9 / 4 / 2010$ & 134 & 753 & 743 & 12238 & 0.0 \\
\hline $9 / 5 / 2010$ & 135 & 760 & 761 & 12546 & 0.0 \\
\hline $9 / 6 / 2010$ & 136 & 705 & 759 & 12503 & 0.0 \\
\hline $9 / 7 / 2010$ & 137 & 651 & 745 & 12274 & 0.0 \\
\hline $9 / 8 / 2010$ & 138 & 619 & 726 & 11961 & 0.0 \\
\hline 9/9/2010 & 139 & 603 & 695 & 11453 & 0.0 \\
\hline $9 / 10 / 2010$ & 140 & 692 & 683 & 11260 & 0.0 \\
\hline $9 / 11 / 2010$ & 141 & 818 & 693 & 11572 & 0.0 \\
\hline $9 / 12 / 2010$ & 142 & 753 & 692 & 11556 & 0.0 \\
\hline $9 / 13 / 2010$ & 143 & 725 & 695 & 11605 & 0.0 \\
\hline $9 / 14 / 2010$ & 144 & 680 & 699 & 11674 & 0.0 \\
\hline $9 / 15 / 2010$ & 145 & 673 & 706 & 11802 & 0.0 \\
\hline $9 / 16 / 2010$ & 146 & 687 & 718 & 12001 & 0.0 \\
\hline $9 / 17 / 2010$ & 147 & 679 & 716 & 11969 & 0.0 \\
\hline $9 / 18 / 2010$ & 148 & 606 & 686 & 11608 & 0.0 \\
\hline $9 / 19 / 2010$ & 149 & 596 & 664 & 11229 & $\overline{0.0}$ \\
\hline $9 / 20 / 2010$ & 150 & 728 & 664 & 11235 & 0.0 \\
\hline $9 / 21 / 2010$ & 151 & 697 & 666 & 11276 & 0.0 \\
\hline $9 / 22 / 2010$ & 152 & 624 & 659 & 11158 & 0.0 \\
\hline $9 / 23 / 2010$ & 153 & 647 & 654 & 11063 & 0.0 \\
\hline $9 / 24 / 2010$ & 154 & 741 & 663 & 11213 & 0.0 \\
\hline $9 / 25 / 2010$ & 155 & 760 & 685 & 11555 & 0.0 \\
\hline $9 / 26 / 2010$ & 156 & 692 & 698 & 11788 & 0.0 \\
\hline $9 / 27 / 2010$ & 157 & 711 & 696 & 11749 & 0.0 \\
\hline $9 / 28 / 2010$ & 158 & 668 & 692 & 11679 & 0.0 \\
\hline 9/29/2010 & 159 & 643 & 695 & 11724 & 0.0 \\
\hline $9 / 30 / 2010$ & 160 & 851 & 724 & 12216 & 0.0 \\
\hline $10 / 1 / 2010$ & 161 & 471 & 685 & 11564 & 0.0 \\
\hline $10 / 2 / 2010$ & 162 & 556 & 656 & 11036 & 0.0 \\
\hline $10 / 3 / 2010$ & 163 & 566 & 638 & 10733 & 0.0 \\
\hline $10 / 4 / 2010$ & 164 & 551 & 615 & 10348 & 0.0 \\
\hline $10 / 5 / 2010$ & 165 & 411 & 578 & 9729 & $\overline{0.0}$ \\
\hline $10 / 6 / 2010$ & 166 & 548 & 565 & 9500 & $\overline{0.0}$ \\
\hline $10 / 7 / 2010$ & 167 & 530 & 519 & 8729 & 0.0 \\
\hline $10 / 8 / 2010$ & 168 & 492 & 522 & 8780 & 0.0 \\
\hline $10 / 9 / 2010$ & 169 & 530 & 518 & 8659 & 0.0 \\
\hline $10 / 10 / 2010$ & 170 & 724 & 541 & 9035 & 0.0 \\
\hline $10 / 11 / 2010$ & 171 & 728 & 566 & 9459 & 0.0 \\
\hline
\end{tabular}


Table A.3: Excess methane production calculation due to co-digestion synergistic outcome based on VS added to digesters

\begin{tabular}{|c|c|c|c|}
\hline & Control & Co-digestion & $\begin{array}{l}\text { Post co- } \\
\text { digestion }\end{array}$ \\
\hline Period considered (days) & 60 & 61 & 50 \\
\hline Total primary sludge VS added (tonnes VS) & 2560 & 2760 & 2130 \\
\hline Total $\mathrm{CH}_{4}$ produced (kCF) & 18,800 & 23,400 & 20,000 \\
\hline Total $\mathrm{CH}_{4}$ produced $\left(\mathrm{m}^{3}\right)$ & 533,000 & 663,000 & 567,000 \\
\hline $\mathrm{L} \mathrm{CH}_{4} / \mathrm{kg}$ VS sludge added & 208 & & \\
\hline Theoretical $\mathrm{CH}_{4}$ production $\left(\mathrm{m}^{3}\right)$ & & 572,000 & 443000 \\
\hline Additional $\mathrm{CH}_{4}\left(\mathrm{~m}^{3}\right)$ & & 90,900 & 124000 \\
\hline Total volume of co-digestate added (gal) & & 237,000 & \\
\hline Average COD of co-digestate (mg/L) & & 59,300 & \\
\hline Total COD added as co-digestate (kg) & & 53,200 & \\
\hline $\mathrm{CH}_{4}$ from co-digestate $\left(\mathrm{m}^{3}\right)$ & & 21,300 & \\
\hline Excess $\mathrm{CH}_{4}\left(\mathrm{~m}^{3}\right)$ & & 69,700 & 124,000 \\
\hline
\end{tabular}

Table A.4: TS removal efficiency calculation

\begin{tabular}{lccc}
\hline & Control & Co-digestion & Post co-digestion \\
\hline Period considered (days) & 60 & 61 & 50 \\
Total primary sludge TS added (tonnes TS) & 3433 & 4061 & 2776 \\
Total co-digestate added TS (tonnes TS) & 0 & 59 & 0 \\
Total TS wasted (tonnes TS) & 2462 & 2686 & 2144 \\
TS accumulation (tonnes TS) & -45 & 91 & -273 \\
TS destroyed (Tonnes TS) & 1016 & 1343 & 905 \\
TS removal efficiency (\%) & $\mathbf{3 0}$ & $\mathbf{3 3}$ & $\mathbf{3 3}$ \\
\hline
\end{tabular}


Table A.5: VS removal efficiency calculation

\begin{tabular}{lccc}
\hline & Control & Co-digestion & Post co-digestion \\
\hline Period considered (days) & 60 & 61 & 50 \\
Total primary sludge VS added (tonnes VS) & 2563 & 2755 & 2133 \\
Total co-digestate added VS (tonnes VS) & 0 & 51 & 0 \\
Total VS wasted (tonnes VS) & 1858 & 1819 & 1431 \\
VS accumulation (tonnes VS) & -114 & 45 & -136 \\
VS destroyed (Tonnes VS) & 819 & 942 & 839 \\
VS removal efficiency (\%) & $\mathbf{3 2}$ & $\mathbf{3 4}$ & $\mathbf{3 9}$ \\
\hline
\end{tabular}


Appendix

B 
Figure B.1: DGGE image at 2 weeks after co-digestion

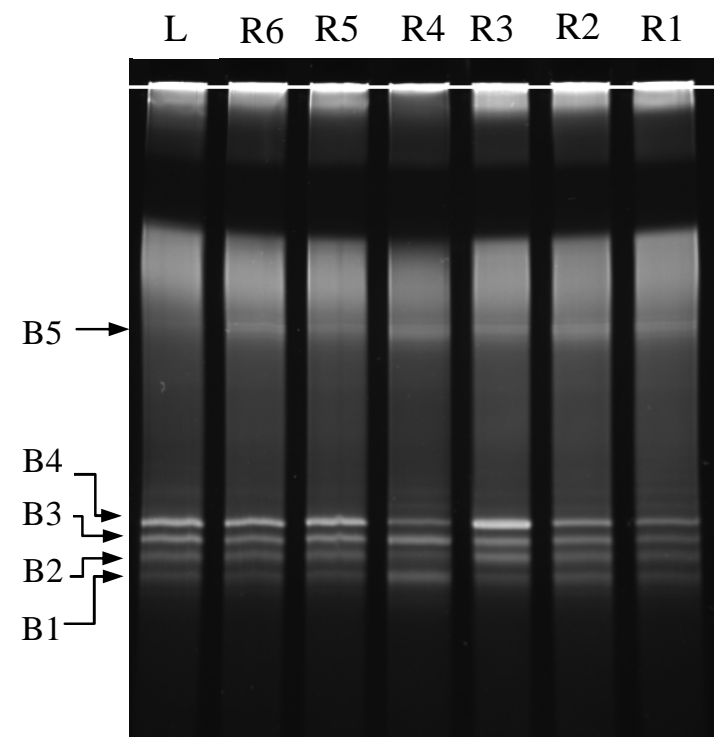

Table B.1: Optical intensities for detected bands from DGGE gels

(a) 2 weeks after start of co-digestion

\begin{tabular}{|c|c|c|c|c|c|}
\hline & Band 1 & Band 2 & Band 3 & Band 4 & Band 5 \\
\hline L & 2.3685 & 3.182 & 3.8481 & 5.9434 & 0 \\
\hline R6 & 2.0683 & 2.909 & 3.2062 & 4.9686 & 12.045 \\
\hline R5 & 2.3386 & 3.2107 & 3.6555 & 5.7005 & 10.093 \\
\hline R4 & 4.4033 & 2.8788 & 4.8294 & 3.3044 & 12.97 \\
\hline R3 & 1.9501 & 3.5133 & 3.6006 & 6.9526 & 10.7429 \\
\hline R2 & 2.5326 & 3.1658 & 3.2897 & 4.5075 & 13.479 \\
\hline R1 & 1.8335 & 2.4092 & 2.2704 & 2.8991 & 11.36 \\
\hline
\end{tabular}

(b) 8 weeks after start of co-digestion

\begin{tabular}{|c|c|c|c|c|c|}
\hline & Band 1 & Band 2 & Band 3 & Band 4 & Band 5 \\
\hline L & 2.1032 & 2.8544 & 3.4139 & 5.3157 & 0 \\
\hline R6 & 2.8063 & 2.5483 & 3.0967 & 5.7859 & 10.055 \\
\hline R5 & 3.171 & 2.9282 & 3.3487 & 6.6044 & 9.7727 \\
\hline R4 & 2.6127 & 3.185 & 2.8804 & 10.2528 & 9.5183 \\
\hline R3 & 2.4769 & 2.8682 & 2.9145 & 8.9754 & 10.018 \\
\hline R2 & 2.4474 & 2.7331 & 2.7552 & 4.3125 & 9.116 \\
\hline R1 & 2.3732 & 2.5306 & 2.3171 & 3.0308 & 9.693 \\
\hline
\end{tabular}


Table B.2: Gene copy and transcript numbers of the biomass obtained from qPCR and their statistical comparison

\begin{tabular}{ccccc}
\hline & \multicolumn{2}{c}{ Gene copy } & \multicolumn{2}{c}{ transcript number } \\
& Average & STDEV & Average & STDEV \\
& per ng DNA & per ng DNA & per ng RNA & per ng RNA \\
\hline Digester 2 & 15436 & 6796 & 9710 & 3710 \\
Digester 3 & 24271 & 6136 & 20700 & 16400 \\
Digester 5 & 14193 & 9689 & 7490 & 2680 \\
& & & & \\
\hline Control and Co-Digestion 1 & t-value & p-value & t-value & p-value \\
\hline Control and Co-Digestion 2 & 1.6713 & $\mathrm{p}=0.170$ & 1.1321 & $\mathrm{p}=0.321$ \\
Co-Digestion 1 and Co-Digester 2 & 0.1819 & $\mathrm{p}=0.864$ & 0.8402 & $\mathrm{p}=0.448$ \\
& -1.5220 & $\mathrm{p}=0.203$ & -1.3769 & $\mathrm{p}=0.241$ \\
\hline
\end{tabular}

